\title{
DIVERSIDADE GENÉTICA E FLUXO GÊNICO VIA PÓLEN E SEMENTE EM POPULAÇÕES DE Solanum Iycocarpum ST.HIL. (SOLANACEAE) NO SUDESTE DE GOIÁS
}

\author{
KARINA MARTINS
}

Tese apresentada à Escola Superior de Agricultura "Luiz de Queiroz", Universidade de São Paulo, para obtenção do título de Doutor em Agronomia, Área de Concentração: Genética e Melhoramento de Plantas.

P I R A C I C A B A

Estado de São Paulo - Brasil

Junho -2005 


\title{
DIVERSIDADE GENÉTICA E FLUXO GÊNICO VIA PÓLEN E SEMENTE EM POPULAÇÕES DE Solanum Iycocarpum ST.HIL. (SOLANACEAE) NO SUDESTE DE GOIÁS
}

\author{
KARINA MARTINS \\ Bacharel em Ciências Biológicas
}

Orientador: Prof. Dr. PAULO YOSHIO KAGEYAMA

\begin{abstract}
Tese apresentada à Escola Superior de Agricultura "Luiz de Queiroz", Universidade de São Paulo, para obtenção do título de Doutor em Agronomia, Área de Concentração: Genética e Melhoramento de Plantas.
\end{abstract}

\footnotetext{
P I R A C I C A B A

Estado de São Paulo - Brasil

Junho - 2005
} 
Dados Internacionais de Catalogação na Publicação (CIP) DIVISÃO DE BIBLIOTECA E DOCUMENTAÇÃO - ESALQ/USP

Martins, Karina

Diversidade genética e fluxo gênico via pólen e semente em populações de Solanum lycocarpum St. Hil. (Solanaceae) no sudeste de Goiás / Karina Martins. - - Piracicaba, 2005

128 p. il.

Tese (doutorado) - - Escola Superior de Agricultura Luiz de Queiroz, 2005. Bibliografia.

1. Cerrado 2. Dispersão de sementes 3. Diversidade genética 4. Fruta-de-lobo 5. Marcador molecular 6 . Reprodução vegetal 7 . Solanaceae I. Título

CDD 633.88 
Aos meus pais, Sueli e Edemir, pela compreensão e pelo apoio incondicional em todas as decisões da minha vida, e aos meus irmãos Edriano e Rafael, por todo amor e carinho,

\section{DEDICO}

"A perseverança tudo vence e pode mais que a força"

A todos aqueles que se empenham em desvendar os mistérios do Cerrado

OFEREÇO 


\section{AGRADECIMENTOS}

Ao Prof. Dr. Paulo Kageyama, pela pronta disposição em me orientar, mas especialmente, pela confiança na minha capacidade até mesmo em momentos em que nem eu mesma acreditava.

Ao Prof. Dr. Lázaro José Chaves e à Marilene pelo carinho, amizade, apoio e pela hospitalidade nas minhas estadias em Goiânia.

Ao Prof. Dr. Roland Vencovsky, pelo interesse em conhecer e discutir os resultados da tese, mas, principalmente, pelo exemplo de humildade e dedicação ao ensino e à pesquisa.

Aos amigos que me auxiliaram nas viagens de campo: Prof. Lázaro, Prof. Vencovsky, Ananda, Deys, Nozimeire, Alexandre Coelho, Sibov, Tânia e Maria Rita. E à Tânia e sua família pela hospitalidade em Morrinhos, GO.

À Carol Morgante pela amizade e carinho durante esses primeiros nove anos de amizade e também por cuidar de mim nos anos em Piracicaba.

Aos amigos do LARGEA, pela confiança, oportunidade de aprendizado e por todo o amor e carinho. Em especial, minha "irmã" Andréia, Flávio Gandara, João, Dodô, Gabi e Renato. E também Gelson, Glauce, Rafael, Pêra, Patrícia e Bia.

À "chefinha" Elza por todo o amor, apoio e preocupação com o meu bem-estar, e à sua família (Éder, Matheus e Nathália), cujo amor é um exemplo de vida para mim.

À Maria Zucchi e à Fernanda Gaiotto pelos ensinamentos e pela pronta ajuda em todos os momentos em que precisei.

Ao Alexandre Sebbenn, ao João, ao Mateus Mondin e à Carol pela leitura criteriosa das partes da tese.

Ao Prof. Dr. Antônio Figueira e ao Henrique pela ajuda nos testes com os locos de cloroplasto. 
Ao Prof. Márcio Elias Ferreira por me fornecer os primers de Capsicum para teste e me informar as seqüências antes mesmo da publicação.

Ao Prof. Márcio de Castro, à Carol e ao Celso pela ajuda no preparo das amostras para seqüenciamento.

Ao Jefferson, ao João e ao Toni pelo auxílio na preparação dos mapas.

Aos funcionários do Departamento de Genética, em especial a Léia, Maídia, Neusa, Fernandinho, Berdã, Valdir, Macedônio, Salete e Carlinhos pelo apoio e amizade.

Aos amigos do PPG em Genética, pelos momentos de estudo e diversão: Marco Aurélio, Mateus Mondin, Américo, Alexandre Missiagia, Aurélio, Juliano, Maria Rita, Glauce, Andréa, Farias, Fred, Éder, Adriano, Dyeme, Bira, Rodrigo Brogin, Vandeco, Matheus 'Quiabo', Phellippe, Leonardecz, Karem, Ana Lúcia, Monaliza, Priscila e Michel.

Aos amigos da APG: Claudia Coelho, Silvia 'Oka', Edmilson e Laércio.

Ao Prof. Dr. Sergius Gandolfi, pelo exemplo de cientista e professor, e aos amigos da UNICAMP, Rejane e Valério, pelos bons momentos de convívio e amizade.

À D. Elenice e ao André Jalles pelo apoio e companhia nos meus primeiros meses em Piracicaba.

Ao Prof. Dr. José Carlos Motta Junior (IB-USP), orientador da iniciação científica por me "apresentar" a lobeira e por me ensinar como "se faz ciência".

À Profa. Dra. Maria Lúcia Carneiro Vieira, coordenadora do PPG em Genética e Melhoramento de Plantas no início do meu curso, pela concessão de auxílio PROAP para algumas viagens a campo.

Ao Prof. Dr. Isaías Olívio Geraldi, coordenador do PPG em Genética e Melhoramento de Plantas, pelo incentivo à passagem para o Doutorado Direto.

Aos professores do PPG em Genética e Melhoramento de Plantas, em especial a Profa. Dra. Elizabeth Ann Veasey.

Ao CNPq pela concessão da bolsa e à FAPESP pelo financiamento do projeto.

Aos meus familiares pelo apoio incondicional, em especial meus pais e meus irmãos, cujo amor aumentou com a distância. 


\section{SUMÁRIO}

Página

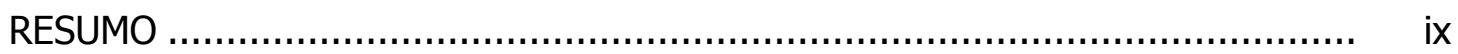

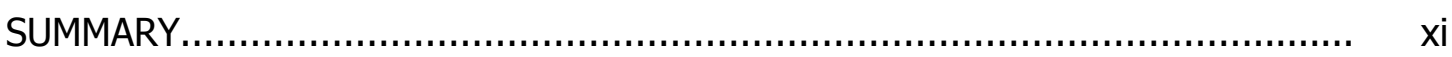

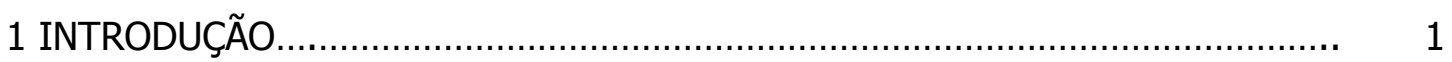

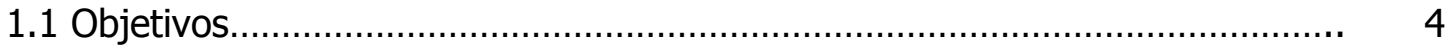

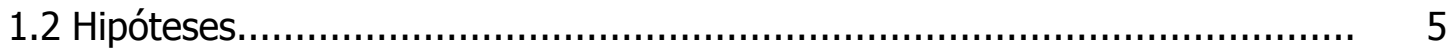

2 REVISÃO DE LITERATURA......................................................... 6

2.10 bioma Cerrado........................................................................ 6

2.2 A devastação do Cerrado....................................................... 8

2.3 Fragmentação de hábitat....................................................... 9

2.4 Seleção de espécies-alvo para ações de conservação................................ 11

2.5 Possíveis efeitos genéticos da fragmentação de hábitat.......................... 12

2.6 Sistema de reprodução........................................................... 14

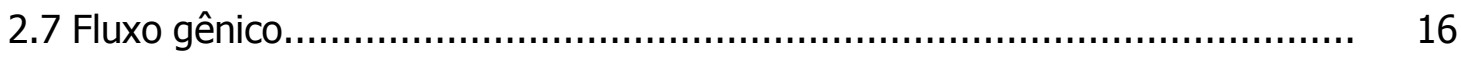

2.7.1 O estudo do fluxo gênico................................................... 17

2.8 Marcadores moleculares microssatélites........................................ 19

2.9 Marcadores moleculares para o estudo do fluxo gênico......................... 21

2.10 Diversidade genética em espécies vegetais do Cerrado....................... 25

2.11 A lobeira ou fruto do lobo (Solanum lycocarpum St.Hil.)..................... 28

3 MATERIAL E MÉTODOS........................................................... 31

3.1 Área de estudo.............................................................. 31

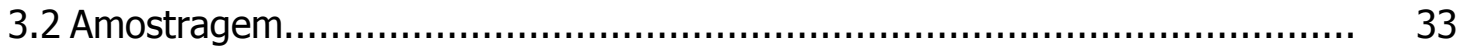

3.3 Coleta de sementes e produção das progênies............................... 35

3.4 Procedimento laboratorial......................................................... 36

3.4.1 Amplificação dos locos microssatélites....................................... 37 


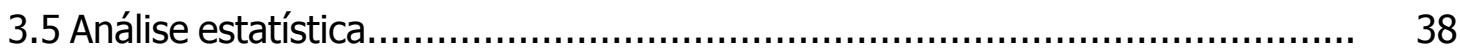

3.5.1 Teste do Equilíbrio de Hardy-Weinberg.............................................. 38

3.5.2 Desequilíbrio genotípico entre pares de locos........................................ 38

3.5.3 Teste da herança do cloroplasto...................................................... 39

3.5.4 Diversidade genética intrapopulacional................................................ 40

3.5.5 Correlação espacial dos genótipos....................................................... 41

3.5.6 Coeficiente de coancestralidade...................................................... 41

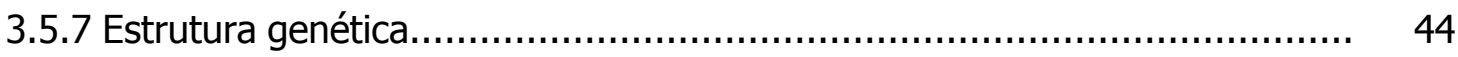

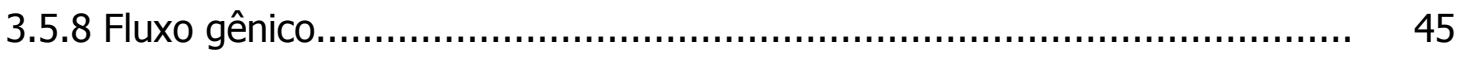

3.5.9 Teste do isolamento pela distância................................................... 46

3.5.10 Colonização na margem da estrada..................................................... 47

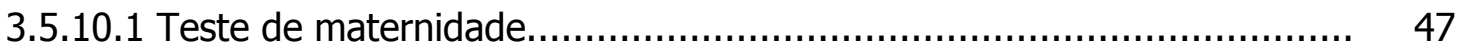

3.5.10.2 Distâncias genéticas................................................................... 48

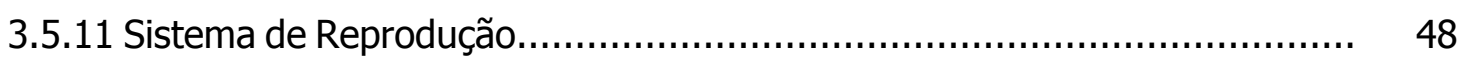

3.5.12 Estimadores para estratégias de conservação.................................... 50

3.5.12.1 Área mínima viável para conservação in situ.................................. 50

3.5.12.2 Número de populações a serem conservadas..................................... 51

3.5.12.3 Número de matrizes para coleta de sementes................................... 51

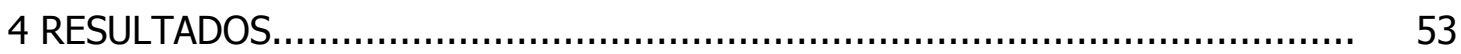

4.1 Amplificação heterológa dos locos microssatélites nucleares......................... 53

4.2 Caracterização dos locos.......................................................................... 54

4.2.1 Marcadores microssatélites nucleares...................................................... 54

4.2.2 Marcadores microssatélites cloroplastidiais............................................... 56

4.3 Teste do Equilíbrio de Hardy-Weinberg............................................... 58

4.4 Desequilíbrio genotípico entre pares de locos.......................................... $\quad 59$

4.5 Herança do genoma cloroplastidial...................................................... 62

4.6 Diversidade genética intrapopulacional................................................. 64

4.6.1 Marcadores microssatélites nucleares................................................... 64

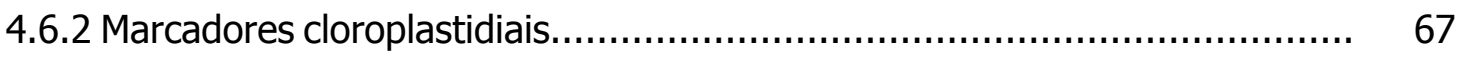

4.7 Correlação espacial dos genótipos....................................................... 71

4.8 Coeficiente de coancestralidade....................................................... 


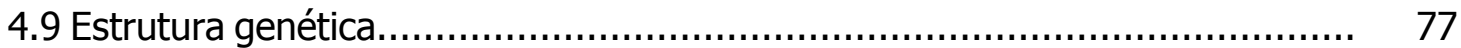

4.9.1 Marcadores microssatélites nucleares................................................. 77

4.9.2 Marcadores cloroplastidiais.......................................................... 78

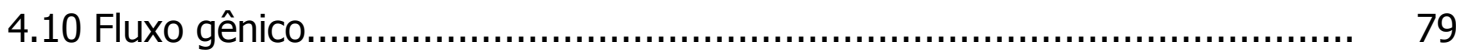

4.11 Teste do isolamento pela distância...................................................... 80

4.12 Colonização na margem da estrada................................................... 81

4.12.1 Teste de maternidade............................................................. 81

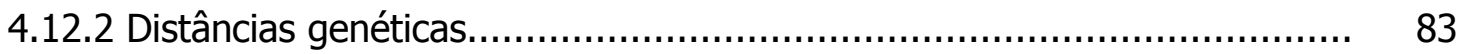

4.13 Sistema de reprodução................................................................ 84

4.14 Estimadores para estratégias de conservação......................................... 89

4.14.1 Área mínima viável para conservação in situ....................................... 89

4.14.2 Número de populações a serem conservadas........................................ 90

4.14.3 Número de matrizes para coleta de sementes...................................... 90

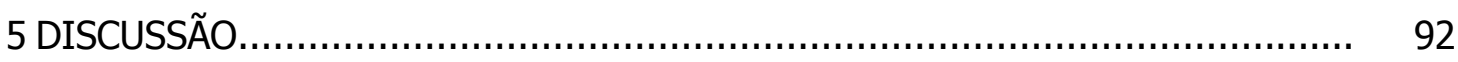

5.1 Amplificação heteróloga.................................................................. 92

5.2 Diversidade genética intrapopulacional................................................ 94

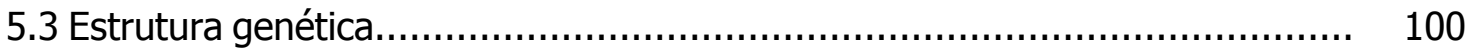

5.4 Indicadores para conservação genética.................................................. 105

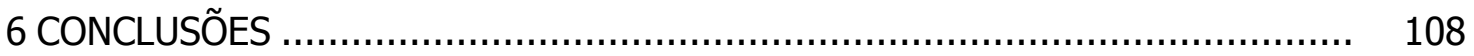

REFERÊNCIAS BIBLIOGRÁFICAS.............................................................. 109 


\title{
DIVERSIDADE GENÉTICA E FLUXO GÊNICO VIA PÓLEN E SEMENTE EM POPULAÇõES DE Solanum lycocarpum ST.HIL. (SOLANACEAE) NO SUDESTE DE GOIÁS
}

\author{
Autora: KARINA MARTINS \\ Orientador: Prof. Dr. PAULO YOSHIO KAGEYAMA
}

\section{RESUMO}

Solanum lycocarpum St.Hil. (Solanaceae) é uma planta lenhosa encontrada nos cerrados e campos cerrados do Brasil Central. É heliófila e característica de formações secundárias abertas. É conhecida popularmente como lobeira. A polpa do fruto é utilizada na produção de um fitoterápico, o polvilho-de-lobeira, amplamente empregado no controle de diabetes e de obesidade, assim como para diminuição no nível de colesterol, sendo comercializado na forma de cápsulas. A espécie é andromonóica, com produção constante de flores hermafroditas e funcionalmente masculinas. A síndrome de polinização é vibrátil e as flores são polinizadas por abelhas do gênero Xylocopa. Os frutos carnosos são consumidos por diversos animais do cerrado. Os principais dispersores das sementes são o lobo-guará, o cachorro-do-mato, a raposa-do-campo, a anta e a formiga saúva. Conhecendo-se as principais características da biologia da reprodução de $S$. lycocarpum e os agentes polinizadores e dispersores de sementes dessa espécie, objetivou-se com esse trabalho estudar a contribuição relativa da migração mediada por pólen e por sementes no fluxo gênico total e na estrutura genética, em quatro populações naturais de $S$. lycocarpum situadas na região Sudeste do estado de Goiás. A razão de fluxo de pólen e semente no fluxo gênico total foi estimada por meio da análise comparativa de marcadores microssatélites nucleares e 
cloroplastidiais. O sistema de reprodução e a distribuição espacial dos genótipos nas populações também foram estudados. Buscou-se, ainda, avaliar a diversidade genética em plantas situadas na margem da estrada de terra que interliga três populações, com o objetivo de inferir sobre a origem das sementes que colonizaram esse ambiente. Os 294 indivíduos amostrados foram estudados com seis locos microssatélites nucleares e seis locos microssatélites cloroplastidiais. Observou-se menor diversidade gênica com os locos nucleares $\left(\hat{H}_{e}=0,330 \pm 0,013\right)$ do que com os locos cloroplastidiais $(\hat{h}=$

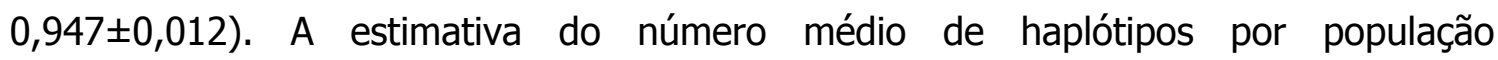
( $\left.\hat{n}_{h}=28,4 \pm 2,67\right)$ mostrou que tanto as populações naturais como a margem da estrada foram fundadas por número elevado de sementes de origens diversas. Estrutura espacial dos genótipos a uma distância de até $50 \mathrm{~m}$ foi observada em duas populações, sendo decorrentes da dispersão de sementes espacialmente restrita. A diferenciação genética entre populações estimada com marcadores cloroplastidiais $\left(\hat{\theta}_{p C}=0,042\right)$ foi ligeiramente menor que a obtida com marcadores nucleares $\left(\hat{\theta}_{p}=0,054\right)$. A razão de fluxo gênico $\left(m_{p} / m_{s}\right)$ para o conjunto de populações foi 1,22 , mostrando que nessa escala de estudo as taxas de fluxo gênico via pólen e sementes são praticamente semelhantes. A margem da estrada foi colonizada por sementes vindas das populações naturais adjacentes e a distância média de dispersão de sementes foi de cerca de $20 \mathrm{~km}$. S. lycocarpum é predominantemente alógama, os cruzamentos entre parentes não são comuns e o número de doadores de pólen nos cruzamentos é superior a dez. Considerando apenas a área de abrangência do presente estudo, é necessário conservar 54 populações para reter um $N_{e}=500$. Na coleta de sementes para conservação ex situ, deve-se coletar igual número de sementes de 150 a 200 matrizes para reter $0 N_{e}=500$ e as matrizes devem estar distantes umas das outras mais de $50 \mathrm{~m}$. 


\title{
GENETIC DIVERSITY AND GENE FLOW BY POLLEN AND SEED IN POPULATIONS OF Solanum lycocarpum ST.HIL. (SOLANACEAE) IN THE SOUTHEAST OF THE STATE OF GOIÁS
}

\author{
Author: KARINA MARTINS \\ Adviser: Prof. Dr. PAULO YOSHIO KAGEYAMA
}

\section{SUMMARY}

Solanum lycocarpum St.Hil. (Solanaceae) is a woody plant that is found in the Brazilian Cerrados (savanna fields) in Central Brazil. It is heliophile, and it features open secondary formations. It's popularly known as wolf's fruit. The meat of its fruit is used in the production of a phytomedicine, the wolf's fruit powder, which is traded in the form of capsules, being widely used for the control of diabetes, obesity and cholesterol levels. The species is andromonoecious, with constant production of hermaphrodite and functionally male flowers. The pollination syndrome is vibratille, and Xylocopa bees pollinate flowers. Various animals in the Cerrado consume the fleshy fruits. The main seed dispersers are the maned wolf, the crab-eating-fox, the hoary-fox, the tapir, and the sauba ant. The main mating features of $S$. lycocarpum as well as its pollinators and seed dispersing agents were used as a basis for this study. Thus, this enquiry aimed at studying the relative contribution of migration mediated by pollen and by seeds in the total gene flow and in the genetic structure of four natural populations of Solanum lycocarpum located in the Southeast region of Goiás State. The pollen to seed flow rate in the total gene flow was estimated by means of comparative analysis of nuclear and chloroplast microsatellite markers. The mating system and genotype spatial distribution in the populations were also studied. We also focused on evaluating the genetic 
diversity in plants located on the dirt roadside that interlinks three of the populations as a means of inferring about the origin of the seeds that colonized the environment. The 294 individuals sampled were studied with six nuclear microsatellite loci and six chloroplast microsatellite loci. The nuclear loci $\left(\hat{H}_{e}=0,330 \pm 0,013\right)$ showed smaller gene diversity than chloroplast loci $(\hat{h}=0,947 \pm 0,012)$. The estimation of the average number of haplotypes per population $\left(\hat{n}_{h}=28,4 \pm 2,67\right)$ indicated that both natural and roadside populations were founded by a great number of seeds of various origins. Genotypes' spatial structure at distance of up $50 \mathrm{~m}$ was detected in two of the populations, resulting from spatially restricted seed dispersion. The genetic differentiation between populations estimated with chloroplast markers $\left(\hat{\theta}_{p C}=0,042\right)$ were slightly smaller than that obtained with nuclear markers $\left(\hat{\theta}_{p}=0,054\right)$. Gene flow ratio $\left(m_{p} / m_{s}\right)$ for the set of populations was 1.22 , showing that gene flow rates by pollen and seed are practically similar in the scale of this study. The roadside was colonized by seeds from adjacent natural populations, and the average seed dispersion distance was about $20 \mathrm{Km}$. S. Iycocarpum is predominantly alogamic. Biparental inbreeding was not common and the number of pollen donors in the crossings was above ten. Considering only the area comprised in this study, it is necessary to preserve 54 populations to retain $N_{e}=500$. When sampling seeds for ex situ conservation, the same number of seeds must be collected from 150 to 200 mothertrees to retain $N_{e}=500$. The mother-trees must be more than $50 \mathrm{~m}$ away from each other. 


\section{INTRODUÇÃO}

O Cerrado constitui-se o segundo bioma brasileiro em extensão territorial, ocupando cerca de dois milhões de $\mathrm{km}^{2}$, o que corresponde a $23 \%$ do território nacional. A biodiversidade total foi estimada em cerca de 160.000 espécies de plantas, animais e fungos, das quais 10.000 espécies vegetais pertencem ao grupo das angiospermas (Dias, 1992). O Cerrado apresenta uma marcante heterogeneidade florística em sua ampla área de distribuição e um elevado nível de endemismo. Cerca de $44 \%$ das espécies de plantas vasculares são endêmicas (Myers et al., 2000).

Cerca de $57 \%$ da vegetação original de cerrado do país já foram completamente destruídas e a metade das áreas remanescentes está bastante alterada. A taxa anual de desmatamento do bioma foi estimada em 1,5\%, ou três milhões de hectares ao ano, taxa dez vezes maior que a estimada para a Floresta Atlântica (Machado et al., 2004). Em decorrência do endemismo e da atual velocidade de devastação, o Cerrado é considerado, desde o ano de 2000, uma das 25 áreas críticas para a conservação mundial (Myers et al., 2000). Essas áreas críticas com endemismo e elevado grau de ameaça de perda de biodiversidade são denominadas "hot spots".

Atualmente, menos de 1,5\% do Cerrado encontra-se protegido em Unidades de Conservação (Ratter et al., 1997). Além disso, a distribuição das áreas protegidas não é homogênea pelo bioma e, como conseqüência, uma parte importante da diversidade não está incorporada na rede nacional de áreas protegidas (Silva \& Bates, 2002). Dessa maneira, um aspecto relativo à conservação desse bioma é identificar as áreas prioritárias para a conservação e planejar o estabelecimento de novas unidades de conservação.

A conservação da diversidade genética é uma pré-condição necessária à manutenção de todos os outros níveis da biodiversidade, e é um componente essencial da sustentabilidade das populações (Boyle, 2000; Namkoong et al., 2002). A redução nos 
hábitats naturais e o subseqüente isolamento espacial das populações causam alterações em processos evolucionários básicos, como deriva genética, seleção, migração e reprodução, os quais resultam em mudanças na diversidade genética. Portanto, para evitar extinções e para manter os níveis de diversidade genética é necessário que esses processos evolucionários estejam conservados (Namkoong et al., 2002).

A execução de estudos genéticos populacionais para todas as espécies que compõem o ecossistema, entretanto, é inviável (Boyle, 2000). Uma solução para esse problema consiste na escolha de espécies que sirvam de modelo e, portanto, podem ser utilizadas como referência para a conservação genética in situ do bioma como um todo. Essas espécies-modelo representam grupos de espécies com características comuns, e que apresentam padrões genéticos e ecológicos extrapoláveis, até certo ponto, para todo o grupo (Kageyama et al., 2001). Com essa abordagem, o principal desafio é a seleção de espécies que sirvam como indicadoras dos efeitos da fragmentação, ou de outros processos antrópicos, como a exploração madeireira e o fogo. Namkoong et al. (2002) definiram alguns critérios que podem ser utilizados para a seleção de espécies indicadoras: se a espécie tem importância ecológica; se é rara; se apresenta interesse econômico; se os vetores de fluxo gênico são especializados entre outros.

Solanum lycocarpum é uma espécie lenhosa típica do Cerrado que apresenta características consideradas por Namkoong et al. (2002) para a seleção de espécies indicadoras. Em primeiro lugar, as características de biologia da reprodução da espécie já foram relativamente bem estudadas, de modo que a quantidade de conhecimento prévio sobre a ecologia da espécie é considerável. S. lycocarpum é andromonóica, com produção constante de flores hermafroditas e funcionalmente masculinas, que são polinizadas por abelhas (Oliveira-Filho \& Oliveira, 1988). Diversos mamíferos realizam a dispersão de sementes em longas distâncias, permitindo a colonização de novos ambientes. Uma vez que os frutos somente completam a maturação após caírem ao chão (Lombardi \& Motta-Junior, 1993), muitas sementes germinam sob a copa da árvore-mãe, ou são dispersas a curtas distâncias por formigas saúvas (Courtenay, 1994). A espécie apresenta eficiente rebrota após corte raso, indicando que pode realizar propagação vegetativa. 
Todas essas informações prévias relacionadas à reprodução de $S$. lycocarpum tornam a espécie interessante para o estudo da distribuição da diversidade genética e fluxo gênico. Como as sementes são dispersas por uma variedade de animais com distâncias variáveis de caminhada, o estudo da contribuição relativa da migração de sementes no fluxo gênico total pode ser útil para quantificar, de maneira mais precisa, o efeito da fragmentação de hábitat sobre os vetores de fluxo gênico. Em outras palavras, é possível avaliar se a fragmentação de hábitat afetará principalmente os agentes polinizadores e/ou os dispersores.

Um segundo aspecto apontado por Namkoong et al. (2002) é a amplitude de distribuição da espécie. S. lycocarpum está amplamente distribuída pelo Cerrado e a sua escolha como espécie indicadora pode ser interessante por possibilitar comparações inter-regionais. O terceiro fator considerado por Namkoong et al. (2002) é a susceptibilidade da espécie aos efeitos adversos da intervenção humana, nesse caso a fragmentação de hábitat. A densidade populacional de $S$. lycocarpum é afetada por alterações antrópicas na vegetação natural. A espécie ocorre em baixa densidade em vegetação preservada, mas coloniza ambientes antrópicos, onde a densidade é elevada. Embora a maior densidade populacional implique no aumento do tamanho efetivo, 0 simples aumento no número de indivíduos da espécie não é sinônimo de sustentabilidade genética.

Outro aspecto considerado é o valor econômico da espécie. Embora os frutos de $S$. lycocarpum apresentem utilidade medicinal comprovada (Dall'Agnol \& von Poser, 2000), a espécie ainda não é intensivamente explorada pelo homem. Entretanto, algumas características fazem com que a espécie tenha amplo potencial de uso em programas de restauração, sendo que as sementes podem ser coletadas para produção de mudas. S. lycocarpum é de início de sucessão, apresenta rápida germinação e emergência (Vidal, 2000), a planta cresce rápido e se adapta bem a situações de escassez hídrica (Chaves-Filho \& Stacciarini-Seraphin, 2001; Elias et al., 2003; Vidal, 2000).

Outro fator considerado por Namkoong et al. (2002) é a importância ecológica da espécie. S. lycocarpum consiste de recurso alimentar a diversos animais do Cerrado, especialmente em períodos críticos do ano. Como a espécie frutifica o ano todo, é uma 
das principais fontes de alimento para o frugívoros durante a estação seca, quando os demais frutos são escassos (Motta-Junior \& Martins, 2002; Rodrigues, 2002). Por ser uma espécie importante para o funcionamento da comunidade que faz parte, $S$. lycocarpum pode, assim, ser considerada uma espécie-chave, como definido por Terborgh (1986). Alguns estudos, inclusive, associaram a presença de $S$. lycocarpum à sobrevivência do lobo guará (Chrysocyon brachyurus), principal consumidor do fruto e dispersor das sementes (Courtenay, 1994; Dietz, 1984).

Estudos sobre a estrutura genética e a quantificação do fluxo gênico via pólen e sementes em populações de $S$. lycocarpum poderão indicar os possíveis efeitos da fragmentação de hábitat na diversidade genética e mostrar se a espécie pode ser selecionada como indicadora dos efeitos da fragmentação de hábitat do Cerrado.

\subsection{Objetivos}

Conhecendo-se as principais características da biologia da reprodução de $S$. lycocarpum e os agentes polinizadores e dispersores de sementes dessa espécie, objetivou-se com esse trabalho estudar a contribuição relativa da migração mediada por pólen e por sementes no fluxo gênico total e na estrutura genética, em quatro populações naturais de Solanum lycocarpum situadas na região Sudeste do estado de Goiás. Os objetivos específicos desse estudo, portanto, foram:

a) Testar a amplificação de iniciadores de microssatélites desenvolvidos para Capsicum spp em Solanum lycocarpum, uma vez que ainda não foram desenvolvidos iniciadores específicos para espécie em estudo;

b) Testar a amplificação de iniciadores microssatélites cloroplastidiais, considerados universais por terem sido utilizados com sucesso em diversas espécies;

c) Caracterizar a diversidade genética intrapopulacional por marcadores microssatélites nucleares e cloroplastidiais;

d) Estudar a distribuição espacial dos genótipos e avaliar a ocorrência de regeneração assexuada nas populações;

e) Quantificar o parentesco médio entre os indivíduos nas populações; 
f) Caracterizar a diversidade genética interpopulacional da espécie por marcadores microssatélites nucleares e cloroplastidiais;

g) Estimar o fluxo gênico aparente e a contribuição relativa da migração de pólen e sementes, por meio da análise comparativa de marcadores microssatélites nucleares e cloroplastidiais;

h) Avaliar a diversidade genética em indivíduos situados em ambientes antrópicos (margens de estrada), buscando inferir sobre a procedência das sementes que colonizaram esses ambientes;

i) Caracterizar o sistema de reprodução da espécie;

j) Com base em indicadores genéticos, propor recomendações para estratégias de conservação in situ e para coleta de sementes.

\subsection{Hipóteses}

Com base nas informações a respeito da biologia da espécie, apresentadas anteriormente, bem como das características dos marcadores genéticos utilizados, algumas hipóteses foram formuladas:

a) A espécie apresenta elevada diversidade genética;

b) Quanto aos indivíduos na margem da estrada, espera-se observar maior diversidade intrapopulacional, em decorrência da colonização por sementes de múltiplas origens;

c) Há estruturação espacial dos genótipos dentro das populações, devido à dispersão de sementes espacialmente restrita e à propagação vegetativa;

d) A espécie é predominantemente alógama;

e) A maior proporção da diversidade genética encontra-se dentro das populações;

f) O fluxo gênico em longa distância ocorre predominantemente por sementes e o fluxo de pólen é espacialmente restrito;

g) Os ambientes antrópicos (margens das estradas) foram colonizados por sementes vindas das populações naturais adjacentes;

h) Há maior diferenciação genética em populações geograficamente mais distantes, como esperado pelo modelo de isolamento pela distância. 


\section{REVISÃO DE LITERATURA}

\subsection{0 bioma Cerrado}

O Cerrado é a maior região de savana e o segundo maior bioma da América do Sul (Silva \& Bates, 2002). Ocupa principalmente a região do Brasil Central e partes do Nordeste do Paraguai e Leste da Bolívia (Ab'Saber, 1977). Devido à sua localização, o Cerrado ocupa uma posição central em relação a outros biomas extensos da América do Sul. É delimitado por dois biomas florestais, Floresta Amazônica e Atlântica, e por duas extensas regiões secas, Caatinga e Chaco (Silva \& Bates, 2002). No Brasil, o Cerrado cobria originalmente cerca de dois milhões de $\mathrm{km}^{2}$, o que corresponde a $23 \%$ do território nacional. A região nuclear do Cerrado estende-se desde a margem da Floresta Amazônica à Norte e à Oeste, a Caatinga à Nordeste e a Floresta Atlântica à Leste, até os estados de São Paulo e Paraná (Bridegwater et al., 2004).

O clima é tropical e caracteriza-se por duas estações bem definidas, uma seca, que se estende de abril a setembro, e uma chuvosa. A precipitação média varia de 800 a $2000 \mathrm{~mm}$, enquanto que a temperatura média anual varia de 18 a $28^{\circ} \mathrm{C}$ (Dias, 1992). Em ampla parte do Cerrado, os solos são distróficos, ácidos e profundos, com baixa disponibilidade de cálcio e magnésio e ricos em alumínio (Ratter et al., 1997). O relevo caracteriza-se por extensos platôs de rochas cristalinas ou sedimentares que atingem de 500 a $1700 \mathrm{~m}$ de altitude, interrompidos por depressões periféricas com altitudes de 100 a $500 \mathrm{~m}$ (Silva \& Bates, 2002).

A vegetação do cerrado é composta por diferentes formações vegetais. De acordo com Coutinho (1978), há desde fisionomias predominantemente campestres, como campo limpo, passando por formações savânicas, como campo sujo, campo cerrado e cerrado "sensu stricto" (em ordem crescente de biomassa lenhosa), e 
florestais (cerradão). As fisionomias savânicas do cerrado são as predominantes, cobrindo cerca de $72 \%$ da área (Silva \& Bates, 2002). Além da vegetação de cerrado, 0 bioma é composto por matas ciliares, veredas, campos rupestres e florestas secas (Ratter et al., 1997; Silva \& Bates, 2002).

Dias (1992) estimou a biodiversidade total do cerrado em cerca de 160.000 espécies de plantas, animais e fungos, sendo que os grupos numericamente mais importantes são os insetos (90.000 espécies), os fungos (40.000) e as angiospermas (10.000). Com relação às espécies arbóreas e arbóreo-arbustivas, as estimativas são variáveis e não há um consenso. Castro et al. (1999) discutem as dificuldades de se estimar, com precisão razoável, o número de espécies devido à inclusão, nos inventários, de espécies que não são tipicamente de cerrado, como espécies invasoras (Cecropia, por exemplo) e as de mata de galeria. Devido às imprecisões, esses autores estabelecem um amplo intervalo entre as estimativas mínima (1.000) e máxima (2.000) de número de espécies. Ratter et al. (1997) acreditam ainda que o valor de 1.000 espécies está superestimado e que o número de espécies arbóreas e arbustivoarbóreas do cerrado não excede 800 .

Uma característica marcante do cerrado em termos de biodiversidade é o nível de endemismo. De acordo com Myers et al. (2000), cerca de 44\% das espécies vasculares são endêmicas. O cerrado apresenta marcante heterogeneidade florística, sendo que são reconhecidas seis províncias fitogeográficas. Levantamentos florísticos realizados nas seis províncias mostraram que $52 \%$ das espécies foram encontradas em apenas uma província e que apenas $4 \%$ em todas as províncias (Bridgewater et al., 2004). A extrema heterogeneidade florística (diversidade beta) tem importantes conseqüências no planejamento de estratégias de conservação desse bioma, uma vez que se torna necessário o estabelecimento de muitas áreas protegidas em toda a extensão do cerrado para que a biodiversidade seja efetivamente conservada (Ratter et al., 1997). Além da biodiversidade, o Cerrado é abundante em recursos hídricos. Nesse bioma encontram-se as nascentes das três maiores bacias hidrográficas da América do Sul; a do Rio São Francisco; a do Rio Amazonas e; a do Rio do Prata (Pires \& Santos, 2000). 


\subsection{A devastação do Cerrado}

Até cerca de 70 anos atrás, a região central do Brasil era esparsamente povoada. A população praticava agricultura de subsistência, com rebanhos de gado em baixa densidade, pastejando a própria vegetação de cerrado, e plantio de algumas culturas (Ratter et al., 1997). A iniciativa do Governo Federal para a integração da região Centro-Oeste ao Sudeste do país iniciou-se na década de 1930 e intensificou-se nas décadas seguintes. A construção da ferrovia Noroeste do Brasil (Bauru-Corumbá), a disponibilidade de terras, a abertura de grandes rodovias (Belém-Brasília e BrasíliaAcre), os projetos de colonização e a construção de Brasília transformaram o CentroOeste em uma das principais áreas de atração populacional. No período de 1950 a 1980, a região Centro-Oeste teve o maior crescimento populacional do país (340\%) (Coelho, 1996).

Durante as décadas de 1970 e 1980, houve um rápido deslocamento da fronteira agrícola com pecuária e agricultura extensiva, incentivado por políticas e programas governamentais como o POLOCENTRO e o PRODECER (Le Bourlegat, 2003). Até 1970, apenas cerca de 5 milhões de hectares do cerrado haviam sido desmatados para o plantio de cereais. Atualmente, cerca de 67 milhões dos 204 milhões de hectares da vegetação original de cerrado do país já foram desmatados e incorporados ao processo produtivo (Araújo e Souza, 2003). A região Centro-Oeste contribui hoje com $25 \%$ dos grãos alimentícios e $40 \%$ do rebanho bovino do país (Ávidos \& Ferreira, $2002^{1}$ citado por Roel \& Arruda, 2003).

A expansão da fronteira agrícola para a região Centro-Oeste resultou no rápido aumento dos processos causadores de degradação do bioma, tais como fragmentação e perda de biodiversidade, intensificação da erosão dos solos e assoreamento dos rios. Um relatório publicado pela organização não-governamental Conservação Internacional (Machado et al., 2004) indicou que dos 204 milhões de hectares originais, 57\% já foram completamente destruídos e a metade das áreas remanescentes estão bastante alteradas. A taxa anual de desmatamento do bioma foi estimada em 1,5\%, ou três

1 Ávidos, M.F.D.; Ferreira, L.T. Frutos dos cerrados: preservação gera muitos frutos. Biotecnologia, ciência e desenvolvimento, Brasília: KL3 Publicações ano 3. n.15, p. 36-41, jul/ago. 2000. 
milhões de hectares ao ano, taxa dez vezes maior que a estimada para a Floresta Atlântica.

Com a perda da biodiversidade, perde-se também a possibilidade do uso sustentável dos recursos genéticos. Roel \& Arruda (2003) afirmam que o cerrado apresenta grande potencial como fonte de recursos naturais nos setores madeireiro, combustível, ornamental, forrageiro, alimentício e farmacêutico. Na área alimentícia destacam-se as espécies frutíferas, principalmente o baru (Dipteryx alata), a mangaba (Hancornia speciosa), o araticum (Annona crassiflora), o pequi (Caryocar brasiliense) e a cagaita (Eugenia dysenterica). Esses frutos são utilizados em pratos típicos, doces, compotas, sorvetes e farinhas, sendo comercializados em feiras livres e mercados da região Centro-Oeste (Roel \& Arruda, 2003).

Devido à elevada concentração de espécies endêmicas e à atual velocidade de perda de hábitat, o Cerrado passou a ser considerado, no ano de 2000, uma das 25 áreas críticas para a conservação mundial (Myers et al., 2000). Essas áreas críticas com endemismo e elevado grau de ameaça de perda de biodiversidade são denominadas "hot spots".

\subsection{Fragmentação de hábitat}

O resultado da extensiva remoção da cobertura vegetal nativa é que a vegetação remanescente é geralmente composta por manchas fragmentadas na paisagem. Em termos biológicos, a fragmentação resulta na redução da área total de hábitat disponível e no aumento do isolamento espacial das populações que habitam os remanescentes, o que leva, em última instância, a um aumento potencial nas taxas de extinção (Saunders et al., 1991; Young et al., 1996).

Em ambientes intensamente alterados, a conservação da biota depende da retenção e manejo dos remanescentes e, portanto, o principal desafio é identificar quais fragmentos apresentam algum valor prático para a conservação e como esses devem ser manejados para reter esses valores (Saunders et al., 1991). Sabe-se, atualmente, que menos de $1,5 \%$ do Cerrado encontra-se protegido em Unidades de Conservação (Ratter et al., 1997). Além disso, a distribuição das áreas protegidas não é 
homogênea pelo bioma e, como conseqüência, uma parte importante da diversidade não está incorporada à rede nacional de áreas protegidas (Silva \& Bates, 2002). Um outro aspecto relativo à conservação desse bioma é identificar as áreas prioritárias para a conservação e planejar o estabelecimento de novas unidades de conservação, como proposto pelo Ministério do Meio Ambiente (MMA, 2002).

A biodiversidade não se refere apenas ao número de espécies, mas está representada por todos os níveis de organização biológica: a comunidade, as espécies, o organismo e os genes (Frankel et al., 1995). Torna-se necessário determinar a escala de estudo para definir os critérios adequados para o planejamento das estratégias de conservação da biodiversidade. A comunidade representa o nível mais complexo de estudo da diversidade, uma vez que abrange a interação dinâmica entre espécies, indivíduos e genes. $\mathrm{O}$ estudo de uma espécie particular engloba a diversidade dos genes às populações e proporciona a medida do nível de diversidade de uma comunidade, já que espécies são entidades que podem ser identificadas, classificadas e contadas (Frankel et al., 1995). Portanto, pode-se avaliar os efeitos da fragmentação, abordando não só a extinção das espécies que habitam um determinado ambiente, mas também pela redução de diversidade intraespecífica e pela perda das interações entre as espécies e dessas com o meio abiótico.

Utilizando a abordagem intraespecífica, a conservação em longo prazo deve objetivar a sobrevivência de uma população em um estado que mantenha o vigor e o potencial para adaptação evolutiva, ou seja, deve-se definir a população mínima viável que garanta a retenção da variabilidade genética necessária para que a espécie continue evoluindo (Soulé, 1996). O principal desafio da biologia de populações em conservação é identificar os fatores de risco genéticos e demográficos cruciais aos quais as populações estão sujeitas (Jain, 1994).

Outro desafio da Biologia da Conservação consiste na selção de espécies indicadoras, uma vez que estudar as características ecológicas e a estrutura genética de todas as espécies que compõem um ecossistema é praticamente inviável (Boyle, 2000; Namkoong et al., 2002). A escolha de espécies vegetais pode se constituir uma estratégia interessante. As espécies vegetais ocorrem em séries de populações 
relativamente isoladas, em que uma certa migração de pólen e sementes ocorre entre elas (Frankel et al., 1995).

\subsection{Seleção de espécies alvo para ações de conservação}

Diversas estratégias para escolha de espécies alvo para as ações de conservação in situ já foram propostas. As espécies-bandeira são aquelas com um apelo carismático, que mobilizam o apoio da sociedade, valorizando o trabalho de conservação (Kageyama et al., 2001). Exemplos de espécies-bandeira são a arara-azul, o mico-leão-dourado e o panda, entre outros. Essas espécies constituem em produto de marketing e, geralmente, não compõem um grupo homogêneo com atribuições lógicas e não auxiliam a compreensão do ecossistema como um todo (Stella, 2002).

Uma outra estratégia para seleção da espécie seria a escolha de espécieschave, como definido por Terborgh (1986). Essas espécies são na maioria das vezes plantas, também denominadas mutualistas-chave por Gilbert (1980), e têm importância ecológica nos ecossistemas por proverem alimento aos chamados elos móveis (animais polinizadores, dispersores e predadores) em situações de deficiência alimentar dentro das comunidades. Como discutido por Stella (2002), a definição das espécies-chave é aquela que melhor aponta quais seriam os recursos mais valiosos para a conservação de todo o ecossistema.

Outra estratégia para selecionar espécies que sejam referência para a conservação é por meio de espécies-modelo. Essas representam grupos de espécies com características ecológicas comuns e que têm padrões genéticos e ecológicos extrapoláveis, até certo ponto, para todo o grupo (Kageyama et al., 2001).

Entre os aspectos a serem considerados no processo de seleção das espécies indicadoras, Namkoong et al. (2002) discutem a necessidade de se escolher espécies que sejam as mais susceptíveis aos efeitos adversos da intervenção humana. Nesse contexto, diferentes tipos de intervenção requerem espécies indicadoras distintas. Um segundo aspecto é que as espécies têm que ser representativas, biológica, ecológica e taxonomicamente. Além das considerações ecológicas, Namkoong et al. (2002) discutem aspectos econômicos relacionados à escolha das espécies indicadoras. Afirmam que é 
importante ter um conhecimento prévio a respeito das características ecológicas e genéticas da espécie e que a mesma apresente uma distribuição ampla, por possibilitar comparações inter-regionais. Com o tempo, o acúmulo de informações obtidas em populações de referência permitirá acessar os indicadores genéticos com menores custos (Namkoong et al., 2002).

Em geral, os diferentes tipos de intervenção humana, como a fragmentação de hábitat, as queimadas, a exploração dos recursos madeireiros e não madeireiros, resultam em alterações na variação genética e na maneira como esta está organizada entre indivíduos e populações. Essas alterações na variação genética são atribuídas a quatro processos evolucionários: (1) deriva genética, (2) seleção, (3) migração e (4) reprodução (Namkoong et al., 2002). Considerando que a manutenção da variabilidade genética em populações antrópicas/fragmentadas depende da conservação dos processos evolucionários, tornou-se necessário definir indicadores para o monitoramento desses processos. Namkoong et al. (2002) propõem quatro indicadores de monitoramento dos processos ecológicos: (1) nível de variação genética, (2) mudança direcional nas freqüências alélicas ou genotípicas, (3) fluxo gênico entre populações, e (4) processos do sistema de reprodução. Aplicando-se esses indicadores em populações das espécies modelo, é possível avaliar o efeito dos diferentes tipos de intervenções humanas nos ecossistemas.

\subsection{Possíveis efeitos genéticos da fragmentação de hábitat}

A estrutura genética das populações de plantas é resultado do sistema de reprodução da espécie e da ação de diversos fatores evolucionários como deriva genética, seleção natural, divergência mutacional e recombinação genética (Ouborg et al., 1999). A distribuição espacial e temporal da variabilidade genética em populações naturais é influenciada principalmente pelo fluxo gênico mediado por pólen e sementes, e também pelo tamanho efetivo da população e pela sua distribuição geográfica (Hamrick \& Godt, 1996).

A redução dos hábitats naturais e o subseqüente isolamento espacial das populações trazem conseqüências tanto para o sucesso reprodutivo como para o fluxo 
gênico das espécies arbóreas. A fragmentação da vegetação afeta a reprodução das plantas que habitam os remanescentes, sendo que a magnitude do efeito está relacionada com a biologia da reprodução da espécie, especialmente as espécies polinizadas e dispersas por animais. (Fuchs et al., 2003; Nason \& Hamrick, 1997; Templeton et al., 1990; Young et al., 1996).

A fragmentação de hábitat pode causar, por exemplo, alteração no comportamento de forrageio do polinizador e redução na taxa de movimento de pólen entre as populações (Aizen \& Feinsinger, 1994; Cunningham, 2000). Pode também provocar uma redução na abundância de polinizadores, resultando em menor produção de frutos e sementes (Aizen \& Feinsinger, 1994) e em menor taxa de cruzamento (Kearns et al., 1998). Aliado ao isolamento espacial, pode ocorrer um isolamento temporal causado pelo florescimento assincrônico dos indivíduos remanescentes (Chase et al., 1996; Nason \& Hamrick, 1997). A fenologia do florescimento determina diretamente o número efetivo de doadores de pólen e a densidade de indivíduos floridos. Ambas as características afetam o padrão de fluxo de pólen entre as árvores, uma vez que árvores que florescem assincronicamente recebem menor quantidade de pólen vindo de outras árvores e exibem maior taxa de autofecundação (Fuchs et al., 2003).

Como conseqüência direta da endogamia, ocorre redução da variabilidade genética e acúmulo de efeitos deletérios, especialmente em espécies alógamas, como a maioria das espécies arbóreas tropicais, em que a carga genética é mais acentuada devido à manutenção de alelos recessivos deletérios presentes nos indivíduos heterozigóticos (Charlesworth \& Charlesworth, 1987; Ellstrand, 1992; Ellstrand \& Ellam, 1993; Young \& Boyle, 2000). O aumento na endogamia, a perda de diversidade genética e o aumento da divergência interpopulacional trazem sérias implicações para a persistência da espécie em curto e em longo prazo. Em curto prazo, a perda de heterozigose pode reduzir o valor adaptativo ("fitness") individual, diminuindo a viabilidade da população remanescente. Em longo prazo, a riqueza alélica reduzida pode limitar a habilidade da espécie a responder a mudanças na pressão de seleção exercida sobre elas (Frankel et al., 1995; Saunders et al., 1991; Young et al., 1996) e, em última instância, pode ocasionar a extinção da espécie. 
A probabilidade dos padrões de fluxo gênico serem mantidos após a fragmentação dependerá da habilidade da espécie em dispersar seus propágulos através da matriz entre os fragmentos. Para espécies polinizadas e dispersas pelo vento, a habilidade pode ser apenas uma função simples da distância entre os fragmentos. Por outro lado, se a espécie é polinizada ou dispersa pela fauna, os padrões de fluxo gênico dependerão da resposta dessas espécies associadas, especialmente sua capacidade de atravessar um hábitat não florestado, que geralmente apresenta menor biomassa e complexidade estrutural em relação à vegetação nativa (Young \& Boyle, 2000). Tanto o sistema de reprodução como o fluxo gênico são determinantes essenciais do tamanho efetivo populacional, que tem importância crítica no planejamento de estratégias de conservação (Hall et al., 1996).

\subsection{Sistema de reprodução}

A reprodução é a maneira pela qual os organismos asseguram que seus genes sejam transmitidos à geração seguinte, sendo que diversas características da biologia das espécies evoluíram para atingir o sucesso reprodutivo. A opção pela reprodução sexual é observada em praticamente todos os organismos, uma vez que possibilita a recombinação do material genético de dois parentais (Adams, 1991) e a formação de novas combinações alélicas. Na maioria das espécies de plantas, a polinização cruzada é preferível à autofecundação e há diversos mecanismos da biologia da reprodução que dificultam e, às vezes, até impedem a ocorrência de autofecundação (Adams, 1991). Como exemplo, há o sistema sexual das espécies (como a dioicia e a monoicia), os mecanismos de auto-incompatibilidade, as características florais e o comportamento dos agentes polinizadores, entre outros (Adams, 1991; Boshier, 2000).

Embora o estudo das características da biologia da reprodução de espécies arbóreas tropicais indique que há fortes barreiras para a ocorrência de autofecundação, esse tipo de estudo não permite a quantificação das taxas reais de autofecundação e dos níveis de cruzamento entre parentes nas populações (Boshier et al., 1995; James et al., 1998). Os métodos tradicionais de estudo do sistema de reprodução de uma espécie são baseados na análise da morfologia floral, em experimentos de cruzamentos 
em casa de vegetação e na observação do comportamento dos polinizadores, e fornecem apenas informações qualitativas (Clegg, 1980). A inferência quantitativa do sistema de reprodução é possível pelo uso de marcadores moleculares (Boshier et al., 2000; James et al., 1998). Por meio da determinação da distribuição dos genótipos nas famílias é possível quantificar geneticamente os resultados dos cruzamentos (Clegg, 1980). A determinação do sistema de reprodução com marcadores genéticos descreve, portanto, a maneira como os gametas dos parentais de uma população se unem (Boshier et al., 1995).

Diversos fatores ecológicos e genéticos podem afetar os padrões de reprodução, resultando na ocorrência de endogamia nas populações e na variação temporal e espacial das taxas de cruzamento: mecanismos de incompatibilidade (Murawski \& Hamrick, 1992); densidade de indivíduos (Hall et al., 1994; Hamrick \& Murawski, 1990; Murawski \& Hamrick, 1992); grau de isolamento geográfico das populações (Murawski \& Bawa, 1994); padrões de florescimento, tais como duração do período de florescimento, sincronia e densidade de indivíduos com flores (Fuchs et al., 2003; Hall et al., 1996; Murawski \& Hamrick, 1991); grau de especialização da síndrome de polinização; disponibilidade e comportamento de agentes polinizadores (Boshier, 2000). As informações obtidas com uso de marcadores genéticos, aliadas a observações a campo, permitem a quantificação desses fatores ecológicos e genéticos e seus efeitos no fluxo gênico e na estrutura genética das populações (Boshier, 2000).

O conhecimento de todos os aspectos do sistema de reprodução de uma espécie é necessário para entender a distribuição da variação genética entre indivíduos e os padrões de fluxo gênico entre e dentro de populações. Com essas informações, é possível avaliar o efeito da ação humana sobre esses processos e estabelecer as estratégias mais adequadas para a conservação e o uso da variação genética (Boshier, 2000). Tem sido observado, por exemplo, que em espécies predominantemente alógamas, a maior parcela da variação genética encontra-se dentro de populações, enquanto que em espécies autógamas a maior parte da variação encontra-se entre as populações (Hamrick \& Murawski, 1990).

Informações a respeito do sistema de reprodução têm importância prática para o sucesso dos programas de melhoramento genético (Boshier et al., 1995). A 
ocorrência de endogamia, em especial a autofecundação, resulta em efeitos deletérios nas populações, tais como, fertilidade reduzida e taxas menores de crescimento das progênies (Boshier et al., 1995; Boshier, 2000) devido ao aumento da homozigose e à expressão da carga genética. A representatividade genética das sementes coletadas, tanto para conservação ex situ como para uso nos programas de restauração e melhoramento genético, demandam o conhecimento da base genética que está sendo amostrada. Se esses programas forem iniciados com uso de sementes com base genética estreita, os problemas decorrentes da endogamia certamente irão ocorrer (Boshier et al., 1995).

\subsection{Fluxo gênico}

Fluxo gênico é um termo coletivo que inclui todos os mecanismos que resultam no movimento de genes de uma população para outra (Slatkin, 1985). Na prática, o fluxo gênico é a força evolucionária mais importante para a homogeneização das freqüências alélicas das populações de uma espécie (Freeman \& Herron, 2001). Considerando genes seletivamente neutros, em populações grandes (em que a deriva pode ser ignorada), se o único fator operante for o fluxo gênico, todas as populações irão convergir para a mesma freqüência alélica (Futuyma, 1992; Ridley, 1996).

Enquanto o fluxo gênico atua no sentido de homogeneizar a variação genética espacial, fatores como mutação, deriva genética (devido ao tamanho populacional finito) e seleção natural têm um efeito oposto e contribuem para a divergência genética entre populações (Hamrick \& Nason, 2000; Slatkin, 1987). A seleção natural favorece a adaptação a condições ambientais locais, provocando a diferenciação genética de populações locais e a deriva genética provoca a fixação aleatória de diferentes alelos nas diferentes populações (Slatkin, 1987).

O papel do fluxo gênico na distribuição da diversidade genética entre e dentro das populações depende tanto da distribuição geográfica da espécie, quanto da importância dos outros fatores evolucionários (Slatkin, 1987). Entretanto, em espécies com elevadas taxas de fluxo gênico, a maior parcela da variação genética encontra-se dentro de populações, enquanto que em espécies com fluxo gênico mais limitado, a 
maior parte da variação genética encontra-se entre populações (Hamrick \& Nason, 2000). O fluxo gênico contribui também para o aumento da diversidade genética, já que introduz novas combinações alélicas nas populações.

A taxa média de fluxo gênico entre populações é, com freqüência, baixa, sendo que os modelos populacionais mostram que a troca de pelo menos um migrante por geração é suficiente para prevenir uma forte diferenciação entre duas populações (Ellstrand \& Elam, 1993). Todavia, a taxa de fluxo gênico efetivo pode ser consideravelmente maior do que sugere a taxa média, se populações locais se extinguirem e os sítios forem recolonizados por sementes vindas de diversas populações. Quanto mais elevada a taxa de extinção e recolonização, maior é a taxa de fluxo gênico e menor a variância nas freqüências alélicas das populações (Futuyma, 1992).

\subsubsection{0 estudo do fluxo gênico}

Há duas abordagens para estudar os padrões de fluxo gênico em populações naturais, a abordagem direta e a indireta. A primeira fornece a estimativa do fluxo gênico atual, enquanto que a segunda indica os níveis históricos de fluxo gênico. Diversos métodos podem ser utilizados para estimar o fluxo gênico com a abordagem direta. Pode-se utilizar estratégias de observação do movimento dos agentes polinizadores e dispersores de sementes ou ainda acompanhar a distância de dispersão de pólen e sementes marcados com corantes (Ouborg et al., 1999; Slatkin, 1985). As metodologias que se baseiam na observação do comportamento dos vetores de fluxo gênico dão apenas um indicativo da distância de migração de pólen e sementes, porém a estimativa do fluxo gênico efetivo somente é confiável quando se utilizam marcadores genéticos (Levin, 1981).

Como destacado por Sork et al. (1998), a abordagem mais efetiva para estimação do fluxo gênico atual é a que utiliza análise de paternidade. Em geral, nas análises de paternidade, utilizam-se progênies com genótipo materno conhecido para inferir a paternidade em um conjunto de potenciais doadores de pólen. Por essa abordagem, pode-se estimar a distribuição das distâncias de dispersão e obter curvas 
de dispersão análogas à curva predita pelo modelo de isolamento pela distância proposto por Wright (1943). O método de análise de paternidade também apresenta algumas limitações, em especial no que se refere à amostragem requerida para obter estimativas confiáveis e ao poder discriminatório do marcador genético utilizado (Sork et al., 1998).

A abordagem indireta baseia-se na distribuição da diversidade genética entre populações para obter a estimativa do número efetivo de migrantes por geração, em uma escala de tempo evolucionária (Hamrick \& Nason, 2000; Sork et al., 1998). Pelo método indireto, a distribuição dos alelos é quantificada e um modelo genético populacional é aplicado para estimar qual taxa de fluxo gênico resultaria em uma distribuição similar (Ouborg et al., 1999). Essa abordagem foi proposta inicialmente por Wright (1931, 1951), utilizando o modelo genético de ilhas e a variância das freqüências alélicas entre as populações como parâmetro de diferenciação genética. Desde então diversas variações foram desenvolvidas, tanto no que se refere ao modelo populacional quanto ao parâmetro genético utilizado (Ouborg et al., 1999). As vantagens e as principais limitações do uso de abordagens diretas e indiretas já foram intensamente discutidas na literatura (Burczyk et al., 2004; Hamrick \& Nason, 2000; Neigel, 1997; Slatkin, 1985; Slatkin, 1987; Slatkin \& Barton, 1989; Sork et al., 1998; Sork et al., 1999).

Na maioria das espécies de plantas, o fluxo gênico ocorre em dois estágios distintos: no movimento de pólen e na dispersão de sementes. Considerando-se a definição de fluxo gênico - movimento efetivo de genes entre populações e subpopulações - um evento de fertilização somente será considerado fluxo gênico efetivo quando for resultante de um grão de pólen imigrante e resultar no estabelecimento do embrião. Analogamente, a dispersão de sementes somente constituirá fluxo gênico quando sementes imigrantes se estabelecerem em uma população (Hamrick \& Nason, 2000). O reconhecimento de que a dispersão de genes em plantas ocorre em dois estágios do ciclo de vida é essencial para o entendimento da distribuição da diversidade genética entre e dentro das populações (Levin, 1981).

Estudos de fluxo gênico com abordagens ecológicas têm mostrado que a distância de migração de pólen e sementes é espacialmente restrita, com curvas de 
distribuição geralmente leptocúrticas (Ouborg et al., 1999; Slatkin, 1985) e com pequena proporção dispersa a longas distâncias. Na maioria das espécies, pólen é raramente transportado a distâncias maiores que 1000 m (Loveless \& Hamrick, 1984). Sementes tendem a ser distribuídas próximas à árvore-mãe e raramente são carregadas a distâncias maiores de 200 m (Howe \& Smallwood, 1982; Levin, 1981).

Uma vez que a distância máxima de dispersão varia entre espécies e experimentos, a regra geral é que a dispersão a longas distâncias é muito rara. Entretanto, algumas comparações entre as taxas de colonização observadas e as preditas pelas curvas de distribuição, descritas pela abordagem ecológica, têm mostrado que a magnitude da dispersão a longas distâncias tem sido subestimada (Ouborg et al., 1999). Como os eventos de dispersão a longas distâncias são, em geral, difíceis de serem mensurados, há poucos trabalhos que buscam caracterizar as distâncias máximas de dispersão (Cain et al., 2000).

Estimativas mais confiáveis da distância de migração de pólen e sementes podem ser obtidas pela integração de abordagens ecológicas e genéticas. $\mathrm{O}$ uso de marcadores moleculares pelo método indireto é interessante por possibilitar o estudo das conseqüências, na estrutura genética das populações, da migração de pólen e sementes, ao invés da quantificação desses eventos per se (Ouborg et al., 1999).

\subsection{Marcadores moleculares microssatélites}

Os primeiros marcadores moleculares foram desenvolvidos na década de 1960. Denominados isoenzimas, esses marcadores são utilizados em uma ampla variedade de espécies. Com o passar dos anos, os avanços na biologia molecular, como a descoberta das enzimas de restrição nos anos 1960 e da reação em cadeia da polimerase (PCR) nos anos 1980, permitiram a introdução de novos tipos de marcadores moleculares com deteç̧ão de polimorfismo diretamente no DNA (Ferreira \& Grattapaglia, 1998; Schlötterer, 2004). A ascensão e queda em popularidade dos diferentes marcadores refletem a contínua melhoria na maneira como a variação genética é acessada, ou seja, o sistema de marcador mais recente, em geral, é o mais informativo (Schlötterer, 2004). Análises comparativas entre os diferentes tipos de marcadores podem ser 
obtidas em Ferreira \& Grattapaglia (1998), Glaubitz \& Moran (2000) e Schlötterer (2004).

Marcadores microssatélites (ou seqüências simples repetidas - SSR) são seqüências de nucleotídeos repetidas em "tandem" cuja unidade de repetição varia de um a cinco pares de base. São encontrados em uma ampla diversidade de espécies eucarióticas e no genoma cloroplastidial de plantas (Jarne \& Lagoda, 1996). São abundantes e com distribuição relativamente homogênea em regiões eucromáticas dos genomas (Schlötterer, 2004). Em plantas, os microssatélites ocorrem em maior densidade em regiões de DNA de cópia única, especialmente em regiões que são transcritas, mas não são traduzidas. A distribuição e a freqüência dos microssatélites no genoma das diferentes espécies é uma função da dinâmica, da história da evolução do genoma e das forças seletivas (Morgante et al., 2002). A expansão do microssatélite em geral segue o modelo de mutação aos passos, com o aumento ou diminuição de um ou dois motivos, resultantes de erros no processo de replicação do DNA, que resultam no deslizamento da polimerase. O modelo de mutação aos passos é considerado o mecanismo predominante de mutação no microssatélite (Chambers \& MacAvoy, 2000), porém a recombinação desigual pode gerar mutações de maior amplitude (Jarne \& Lagoda, 1996).

Uma propriedade interessante dos locos microssatélites é a possibilidade de amplificação heterológa em espécies filogeneticamente próximas, decorrente da homologia entre as seqüências de DNA que flanqueiam os microssatélites (Chambers \& MacAvoy, 2000; Jarne \& Lagoda, 1996). A transferência de iniciadores já foi observada em diversas famílias de plantas, tanto entre espécies do mesmo gênero como entre diferentes gêneros de uma família. Há exemplos publicados nas famílias Meliaceae (White \& Powell, 1997), Caryocaceae (Collevatti et al., 1999), Solanaceae (Provan et al., 1996; Sardagna et al., 2001; Smulders et al., 1997), Arecaceae (Gaiotto et al., 2001), Fabaceae (Daynandan et al., 1997), Fagaceae (Steinkellner et al., 1997), Euphorbiaceae (Roa et al., 2000), Myrtaceae (Brondani et al., 1998; Zucchi et al., 2002), entre outros.

Após a amplificação específica por PCR, os alelos de um loco são identificados por meio da migração relativa em gel de eletroforese. Os microssatélites são 
codominantes e apresentam herança mendeliana simples. São considerados seletivamente neutros e, em geral, são altamente polimórficos em populações naturais. Devido ao elevado poder discriminatório, decorrente do multialelismo, esses marcadores são amplamente utilizados em mapeamentos genéticos, em genética forense e em análises mais refinadas de genética populacional, tais como a estimação de coeficientes de parentesco e os testes de paternidade (Chambers \& MacAvoy, 2000; Ferreira \& Grattapaglia, 1998; Glaubitz \& Moran, 2000; Schlötterer, 2004).

Tanto o modelo de mutações aos passos, como as elevadas taxas de mutação estimadas para os microssatélites, da ordem de $10^{-3}$ de acordo com Goldstein \& Pollock (1997), podem resultar em homoplasia de tamanho entre genótipos. Nesse caso, alelos idênticos em tamanho podem ser resultantes de linhagens distintas, ou seja, serem alelos idênticos por estado, mas não idênticos por descendência (Estoup et al., 2002). Conseqüências da falsa inferência de identidade por descendência dos alelos são a superestimação dos coeficientes de parentesco (Chambers \& MacAvoy, 2000) e o viés nas estimativas de divergência entre populações baseada em estatísticas que não consideram o modelo de mutações aos passos (Jarne \& Lagoda, 1996).

Estatísticas para estimação da divergência entre populações que consideram o modelo de mutações aos passos já foram propostas (Goodman, 1997; Slatkin, 1995). Com uso dessas metodologias, em estudos com marcadores microssatélites, é possível calcular o fluxo gênico e migração entre populações naturais com razoável confiabilidade (Chambers \& MacAvoy, 2000).

\subsection{Marcadores moleculares para o estudo do fluxo gênico}

Uma maneira de avaliar as contribuições relativas da migração de pólen e de sementes no fluxo gênico total consiste em quantificar a diferenciação dos marcadores moleculares com variados modos de herança. Os marcadores nucleares apresentam herança biparental, sendo transportados tanto via pólen como via semente. Os marcadores citoplasmáticos, por outro lado, geralmente apresentam herança uniparental. O genoma cloroplastidial, em particular, é maternalmente herdado na 
maioria das angiospermas, sendo transportado apenas via semente (Ennos, 1994; Hu \& Ennos, 1997; Ouborg et al., 1999).

A quantificação das parcelas que compõem o fluxo gênico total de uma espécie em ambiente natural é útil para a avaliação dos efeitos da fragmentação de hábitats no movimento de pólen e na dispersão de sementes (Hamilton, 1999). É útil também na definição de estratégias de conservação in situ e ex situ, uma vez que esse tipo de informação permite a mensuração da perda de diversidade genética nesses programas (Hamrick \& Godt, 1996).

A análise de marcadores citoplasmáticos é amplamente utilizada em Sistemática Filogenética, tanto na construção de genealogias, como nos estudos de introgressão e hibridação (McCauley, 1995). Apenas recentemente a análise de marcadores citoplasmáticos passou a ser utilizada em estudos genéticos de escala populacional, pois se acreditava que o alto grau de conservação dos genomas de mitocôndrias e cloroplastos resultaria na insuficiência de polimorfismos necessários para esse tipo de estudo (McCauley, 1994; Neigel, 1997). O número de trabalhos utilizando os marcadores citoplasmáticos para estudo do fluxo gênico aumentou significativamente nos últimos anos. Em pouco mais de uma década, a estrutura genética populacional de quase duzentas espécies já foi estudada com uso de marcadores citoplasmáticos. Em uma revisão recente, Petit et al. (2005) constataram que cerca de $30 \%$ dos trabalhos utilizando marcadores citoplasmáticos foram publicados depois de 2003.

O genoma cloroplastidial é preferencialmente estudado em comparação ao mitocondrial (Petit et al., 2005) por diversas razões: o cloroplasto é abundante nas células foliares e é fácil de ser isolado; o DNA é pequeno e varia pouco em tamanho, estrutura e ordem dos genes; o modo de evolução do genoma é simples e conservativo e a taxa de mutação é mais elevada em regiões não codificadoras do genoma como introns e espaçadores intergênicos (Mongensen, 1996). Essa última característica facilita o desenvolvimento de sondas e iniciadores que são utilizados em uma ampla variedade de espécies vegetais, sendo por isso denominados iniciadores universais.

A grande maioria dos polimorfismos observados no DNA do cloroplasto consiste em variações de comprimento resultantes de pequenas inserções e deleções, as quais envolvem seqüências de 1-10 pares de bases localizadas em regiões não codificadoras 
do genoma (Palmer, 1987). O primeiro marcador cloroplastidial desenvolvido foi o mapeamento dos sítios de restrição (RFLP - "Restriciton Fragment Lenght Polymorphism"), técnica similar à desenvolvida para o estudo do DNA nuclear. Por essa técnica, o DNA do cloroplasto é extraído das células, purificado e clivado com enzimas de restrição. Após a eletroforese, os polimorfismos são observados após hibridação com uma sonda específica.

O desenvolvimento de iniciadores universais (Taberlet et al., 1991; Demesure et al., 1995) e a descoberta de que o DNA de cloroplasto exibe maior grau de polimorfismos do que se imaginava facilitaram o uso deste marcador em análises genéticas populacionais. Com o desenvolvimento dos iniciadores, a técnica de PCRRFLP passou a ser mais freqüentemente utilizada. Por essa técnica, procede-se à extração de DNA total das células e, posteriormente, seqüências de regiões não codificadoras dos cloroplastos são amplificadas e clivadas com enzimas de restrição. Cerca de $46 \%$ dos trabalhos revisados por Petit et al. (2005) utilizaram a metodologia de PCR-RFLP.

Seqüências repetidas do tipo microssatélite também foram observadas em genomas cloroplastidiais (Provan et al., 1999). Os microssatélites cloroplastidiais consistem tipicamente de oito a 15 repetições de mononucleotídeos. O polimorfismo é muito variável entre locos e entre espécies (Navascués \& Emerson, 2005). Esses marcadores são usados em uma variedade de estudos em escala populacional (Navascués \& Emerson, 2005; Petit et al., 2005; Provan et al., 1999). Iniciadores conservados para a amplificação de microssatélites cloroplastidiais já foram desenvolvidos para coníferas (Vendramin et al., 1996), gramíneas (Provan et al., 2004) e dicotiledôneas (Weising \& Gardner, 1999).

Como se assume que o genoma cloroplastidial não sofre recombinação, tanto os locos de RFLP como os de microssatélites estão geneticamente ligados. A caracterização dos genótipos nos indivíduos consiste da combinação dos alelos observados em cada loco. Essa combinação é denominada haplótipo (Navascués \& Emerson, 2005). Embora seja mais amplamente utilizado em análises filogenéticas, o seqüenciamento de regiões específicas do DNA do cloroplasto também é utilizado em estudos populacionais. 
O estudo do fluxo gênico por marcadores cloroplastidiais é preferencialmente realizado com uso da abordagem indireta, em que o fluxo gênico é inferido com base na divergência genética entre populações (Ennos, 1994). Pressuposições teóricas mostram que o fluxo gênico estimado com marcadores de herança materna (como o cloroplasto em angiospermas) é menor que o estimado com marcadores nucleares, os quais apresentam herança biparental (Ennos, 1994). O DNA nuclear é transportado tanto por pólen quanto por semente, enquanto que o DNA cloroplastidial somente é transportado por sementes. Além disso, como o DNA do cloroplasto é haplóide e herdado sem recombinação, o tamanho efetivo do genoma é menor, o que resulta em maior diferenciação entre populações com esses marcadores (Birky et al., 1989).

A pressuposição de maior diferenciação genética populacional com marcadores cloroplastidiais tem sido corroborada pelos estudos experiemtnais. Petit et al. (2005) observaram que em $97 \%$ das 93 espécies angiospermas e gimnospermas estudadas, a diferenciação genética com marcadores nucleares foi inferior à diferenciação medida com marcadores de herança materna. De acordo com os mesmo autores, o valor médio da diferenciação genética obtida com marcadores cloroplastidiais em 124 espécies de angiospermas foi de $0,637( \pm 0,002)$, enquanto que para marcadores nucleares em 77 espécies de angiospermas foi de $0,184( \pm 0,002)$.

A diferenciação populacional, obtida com marcadores nucleares e cloroplastidiais, depende também das taxas de migração de pólen e sementes, da taxa de cruzamento e do modo de herança das organelas (Hamilton \& Miller, 2002; Petit et al., 1993). Com a ocorrência de autofecundação, os genes nucleares dispersam-se apenas via sementes, logo, em espécies com sistema misto de reprodução, a dispersão média de genes nucleares via pólen é reduzida por um fator igual à taxa de autofecundação (Hamilton \& Miller, 2002). A ocorrência de transmissão paterna do cloroplasto tem um efeito significativo no nível de diferenciação populacional medida com marcadores cloroplastidiais, uma vez que possibilita a dispersão desses genes via pólen. Mesmo uma reduzida taxa de transmissão paterna do cloroplasto resulta em queda significativa na diferenciação populacional estimada com esses marcadores (Petit et al., 1993). 
As taxas de migração de pólen e sementes são muito variáveis entre as espécies, uma vez que a combinação das características de biologia da reprodução e dos vetores de polinização e dispersão de sementes resulta em diferenças nas taxas e nas distâncias de fluxo gênico mediado por pólen e semente. Além disso, embora o conhecimento das características e do comportamento dos vetores de polinização e dispersão mostre que a contribuição do movimento de pólen e semente no fluxo gênico total varia com a escala geográfica de estudo, poucos trabalhos buscaram avaliá-la em diferentes escalas espaciais (Trapnel \& Hamrick, 2004). Pesquisas com essa abordagem foram publicadas por McCauley (1994), Oddou-Muratorio et al. (2001), Trapnel \& Hamrick (2004). Em espécies generalistas cujas sementes são dispersas por uma variedade de animais, com diferentes hábitos de forrageamento e capacidades de movimentação distintas, o padrão de dispersão de sementes e a sua contribuição no fluxo gênico total são variáveis com a escala espacial de estudo.

A abordagem de estudo em diferentes escalas geográficas é particularmente interessante em espécies de plantas em que o potencial de dispersão de sementes a longas distâncias excede o potencial de migração de pólen (Trapnel \& Hamrick, 2004) e também em espécies que apresentam dinâmica de metapopulações, em que a contribuição relativa do fluxo gênico por sementes é acentuada devido a sua contribuição para a fundação de novas populações. No Cerrado, a ocorrência de fogo pode ser considerada uma fonte relativamente constante de distúrbio nas populações e, portanto, a eficiência da dispersão de sementes na fundação de novas populações torna-se importante para a manutenção da variabilidade genética e da persistência das espécies em longo prazo.

\subsection{Diversidade genética em espécies vegetais do Cerrado}

O interesse em estudar a estruturação genética em populações de espécies vegetais do Cerrado é recente, sendo que a maioria dos trabalhos foi publicada depois de 2000. Devido ao potencial de exploração econômica, as espécies nativas frutíferas são preferencialmente estudadas. Diversos estudos, por exemplo, abordaram a estrutura genética de populações de Caryocar brasiliense (pequizeiro), uma das 
espécies frutíferas mais características do Cerrado, com a utilização de uma variedade de marcadores moleculares. Collevatti et al. (2001a, 2001b) e Souza-Júnior (2003) utilizaram marcadores microssatélites, Melo Junior et al. (2004) utilizaram marcadores isoenzimáticos, Collevatti et al. (2003) usaram dois tipos de marcadores cloroplastidiais e Araújo (2001) trabalhou com marcadores RAPD.

A espécie frutífera Eugenia dysenterica (cagaiteira) também foi estudada com o uso de diversos marcadores genéticos. Telles et al. (2001a, 2001b, 2003b) utilizaram marcadores isoenzimáticos, Zucchi (2002) e Trindade (2001) utilizaram marcadores RAPD e, Zucchi (2002) e Zucchi et al. (2003) utilizaram marcadores microssatélites. A espécie Annona crassiflora (araticunzeiro), também frutífera, foi estudada por Telles et al. (2003a), com marcadores isoenzimáticos.

Outras espécies arbóreas do Cerrado com interesse econômico foram estudadas com uso de marcadores RAPD. Lacerda et al. (2001) estudaram Plathymenia reticulata (vinhático), Pereira (2003) avaliou a diversidade genética de três espécies: Hymenaea stignocarpa (jatobá-do-cerrado), Bowdichia virgilioides (sucupira-preta), Qualea grandiflora (pau-terra) e Zelandi et al. $(1999,2000)$ estudaram populações de Solanum lycocarpum (lobeira).

De modo geral, esses estudos com espécies arbóreas do Cerrado demonstraram uma tendência a taxas de cruzamento e níveis de diversidade genética elevados, bem como significativa divergência entre populações e estruturação espacial dos genótipos, resultantes da limitação do fluxo gênico a longas distâncias. Observou-se também que, embora a taxa de cruzamento seja elevada, nas espécies $C$. brasiliense (Collevatti et al., 2001a) e $E$. dysenterica (Telles et al., 2003b), o cruzamento entre parentes e o número restrito de doadores de pólen participando dos cruzamentos são fontes significativas de endogamia e/ou parentesco nas populações.

Em A. crassiflora (Telles et al., 2003a), por outro lado, a observação de parentesco e divergência entre as populações foi relacionada com a ocorrência de deriva genética e efeito fundador, resultante da fundação de novas populações por sementes originadas de poucos frutos. Contrariamente do que foi observado em $A$. crassiflora, Collevatti et al. (2003) constataram que, em C. brasiliense, as populações 
são fundadas por múltiplas linhagens maternas, demonstrando a eficiência do processo de dispersão de sementes dessa espécie na colonização de novas áreas.

Praticamente todos os estudos com as espécies arbóreas do Cerrado mostraram que, devido à estruturação espacial da variação genética, tanto para a definição das estratégias de conservação in situ, como na coleta de sementes, deve-se priorizar a amostragem de número elevado de populações e subpopulações geograficamente distantes. Souza Júnior (2003) recomenda a amostragem de populações $C$. brasiliense distantes em um raio de seis a $12 \mathrm{~km}$ e Telles et al. (2003b) sugerem que, para $E$. dysenterica, sejam amostradas populações distantes $120 \mathrm{~km}$ umas das outras.

Embora diversos estudos com espécies arbóreas do Cerrado foram publicados recentemente, ainda há lacunas no conhecimento sobre a diversidade genética das espécies do Cerrado que precisam ser preenchidas. Poucos estudos, por exemplo, avaliaram o sistema de reprodução de maneira detalhada e nenhum deles estimou o fluxo atual de pólen. Ainda que praticamente todos os autores argumentem sobre os riscos da rápida taxa de devastação do bioma, o efeito da fragmentação de hábitat ainda não foi sistematicamente avaliado, especialmente porque há o predomínio de utilização da abordagem indireta de estimação de fluxo gênico e também porque a fragmentação do bioma é recente. Apenas em um estudo com Caryocar brasiliense (Collevatti et al., 2003) utilizou-se a abordagem comparativa com marcadores nucleares e cloroplastidiais para avaliar a contribuição relativa de pólen e sementes no fluxo gênico total. Ressalta-se também a marcante extensão territorial do bioma e a necessidade de estudos que abranjam maiores amplitudes geográficas. A quase totalidade dos trabalhos foi realizada no estado de Goiás e no Distrito Federal, sendo que os estados de Mato Grosso, Mato Grosso do Sul e Tocantins foram poucos estudados.

O agrupamento das espécies de plantas com características semelhantes de biologia da reprodução, tais como síndromes de polinização e dispersão de sementes, e a comparação dos padrões de diversidade genética das espécies que compõem os diferentes grupos constitui-se uma estratégia interessante para conhecer, de maneira mais abrangente, os fatores ecológicos e evolucionários determinantes dos padrões de variação genética nas populações desse bioma. 


\subsection{A lobeira ou fruto do lobo (Solanum Iycocarpum St.Hil.)}

Solanum lycocarpum St.Hil. (Solanaceae) (2n=24; Coleman, 1982) é um arbusto lenhoso de crescimento rápido cuja área de distribuição engloba os cerrados e campos cerrados do Brasil Central (Courtenay, 1994; Oliveira-Filho \& Oliveira, 1988). A espécie é característica e exclusiva de formações secundárias abertas, ocupando tanto solos argilosos como arenosos, bem drenados e de baixa fertilidade (Lorenzi, 1998). É comumente observada em ambientes perturbados pelo homem como margens de estrada, pastos e terrenos baldios (Oliveira-Filho \& Oliveira, 1988; Rodrigues, 2002).

As inflorescências, com seis a treze flores, distribuem-se por toda a copa do arbusto e extremidades dos ramos (Oliveira-Filho \& Oliveira, 1988). As características florais concordam com a síndrome da melitofilia (Pijl, 1972) e da polinização vibrátil (Buchmann, 1983), em que a vibração da abelha na flor provoca uma nuvem de pólen. A antese é diurna, as flores apresentam padrões de ultravioleta, há áreas de emissão de odor adocicado, os estames amarelos são vistosos, as anteras apresentam deiscência poricida e são coniventes ao redor do estilete (Buchmann, 1983; OliveiraFilho \& Oliveira, 1988). Essa combinação de elementos que definem a síndrome de polinização vibrátil é característica das espécies do gênero Solanum (Bezerra \& Machado, 2003; Buchmann, 1983).

As abelhas do gênero Xylocopa são consideradas os polinizadores mais freqüentes e eficientes (Oliveira-Filho \& Oliveira, 1988). Testes de polinização controlada indicam que $S$. lycocarpum possivelmente apresenta mecanismos de autoincompatibilidade, já que apenas os experimentos de polinização cruzada resultaram na formação de frutos (Oliveira-Filho \& Oliveira, 1988). A espécie floresce durante todo o ano, com predominância na estação chuvosa (Rodrigues, 2002).

S. lycocarpum é andromonóica, sendo que no mesmo indivíduo podem ser encontradas flores hermafroditas e flores funcionalmente masculinas (com ovário atrofiado) (Oliveira-Filho \& Oliveira, 1988). A proporção dos tipos de flores nas árvores é variável (Moura, 2004; Oliveira-Filho \& Oliveira, 1988), como também observado em outras espécies andromonóicas (Diggle, 1993). 
O fruto é grande, esférico, de coloração verde mesmo quando maduro, atingindo $8-15 \mathrm{~cm}$ de diâmetro e $200-900 \mathrm{~g}$. A polpa é amarela e abriga cerca de $300-$ 800 pequenas sementes pretas subovais. Após a queda do fruto, ocorre a maturação completa e a emissão de aroma característico (Lombardi \& Motta-Junior, 1993). Os frutos são consumidos por animais silvestres, especialmente mamíferos de médio e grande porte (Rodrigues, 2002). A dispersão de sementes é por endozoocoria, sendo que os principais agentes dispersores são o lobo-guará (Chrysocyon brachyurus) (Dietz, 1984; Lombardi \& Motta-Junior, 2003; Motta-Junior \& Martins, 2002; Motta-Junior et al., 1996; Rodrigues, 2002), o cachorro-do-mato (Dusicyon thous) (Bueno \& MottaJunior, 2004; Rodrigues, 2002), a raposa-do-campo (Lycalopex vetulus) (Dalponte \& Lima, 1999; Rodrigues, 2002) e a anta (Tapirus terrestris) (Pinto, 1998; Rodrigues, 2002). Morcegos (Lorenzi, 1998; Rodrigues, 2002), o veado-mateiro (Mazama americana), a cutia (Dasyprocta) (Rodrigues, 2002) e o lagarto teiú (Tupinambis merianae) (Castro \& Galetti, 2004) também já foram observados alimentando-se de frutos de $S$. lycocarpum. Porém, a atuação desses animais na dispersão de sementes ainda não foi avaliada.

As formigas saúvas também desempenham importante papel na dispersão secundária das sementes (Courtenay, 1994; Martins \& Motta-Junior; 2000; Pinto et al., 2000). Os principais predadores das sementes são besouros e roedores (Pinto, 1998; Rodrigues, 2002). A predação por papagaios (Amazona sp), embora seja rara, também foi observada (Pinto, 1998).

A polpa do fruto é utilizada na produção de um fitoterápico, o polvilho-delobeira, amplamente empregado no controle de diabetes e de obesidade, assim como para diminuição no nível de colesterol, sendo comercializado em farmácias de todo o país na forma de cápsulas (Dall'Agnol \& von Poser, 2000). Os frutos são utilizados por comunidades rurais na confecção de doces (Silva et al., 1994), para uso tópico em picadas de cobras e na produção de um xarope contra a asma (Pio Corrêia, 1984). Além do fruto, outras partes da planta são aproveitadas medicinalmente. As folhas são reputadas para tratamento de epilepsia, espasmos e dores abdominais e renais (Cruz, 1982). As flores são empregadas no tratamento de hemorróidas e de gripe, como expectorante, e as raízes são utilizadas contra a hepatite (Pio Corrêia, 1984). 
Adicionalmente ao potencial medicinal, acredita-se que essa espécie contribua para a conservação de uma espécie da fauna brasileira ameaçada de extinção, o lobo guará - Chrysocyon brachyurus. Estudos sobre a dieta alimentar deste canídeo (Dietz, 1984; Motta-Junior \& Martins, 2002; Motta-Junior et al., 1996) indicam que, embora sua dieta seja onívora e oportunista, o consumo de $S$. lycocarpum é elevado e constante durante todo o ano. Trabalhos sobre a dispersão de sementes da lobeira demonstram que o lobo guará é o principal dispersor dessa espécie (Rodrigues et al., 2000). É considerado um dispersor legítimo e eficiente, já que praticamente não danifica as sementes que consome e as defeca em locais em que a planta ocorre freqüentemente, como margens de estradas (Martins \& Motta-Junior, 2000). A relação desse canídeo com $S$. lycocarpum é tão marcante que essa espécie é conhecida popularmente como lobeira ou fruta-do-lobo. 


\section{MATERIAL E MÉTODOS}

\section{1 Área de estudo}

A pesquisa foi realizada na região Sudeste do estado de Goiás, abrangendo os municípios de Bela Vista de Goiás, São Miguel do Passa Quatro, Orizona e Morrinhos. O relevo da região caracteriza-se por chapadas com cerca de 800 a $1000 \mathrm{~m}$ de altitude, ocupadas por monoculturas de soja e milho e por vales dos rios da Bacia do Rio Corumbá, afluente do Rio Paranaíba. A devastação de áreas extensas de vegetação original na região é relativamente recente. Anteriormente à década de 1970, a ocupação humana caracterizava-se por pecuária extensiva e agricultura de subsistência, de modo que boa parte da vegetação original encontrava-se preservada. O emprego de técnicas para o preparo de solo, como calagem e adubação, bem como o plantio de gramíneas exóticas nos pastos iniciou-se na década de 1970, concomitantemente com as primeiras plantações em larga escala de monoculturas de soja e milho. Nas áreas adjacentes às populações de estudo, o plantio de soja e milho é ainda mais recente, tendo sido iniciado entre os anos de 1998 e 2000.

De modo geral, as plantações ocuparam as regiões mais planas onde havia antigas áreas de pastagens. As encostas das chapadas, assim como os vales, apresentam vegetação de cerrado preservado e pastagens. ${ }^{2} \mathrm{O}$ clima caracteriza-se por ser tropical estacional com um regime de chuvas no verão. A precipitação média anual fica em torno de $1500 \mathrm{~mm}$ e as temperaturas médias são de $27^{\circ} \mathrm{C}$ (Ribeiro \& Silva, 1996). Foram demarcadas quatro áreas para coleta de $S$. lycocarpum, localizadas em propriedades particulares (Figura 1).

\footnotetext{
${ }^{2}$ Histórico de ocupação da região Sudeste de Goiás - Prof. Lázaro Chaves (comunicação pessoal).
} 


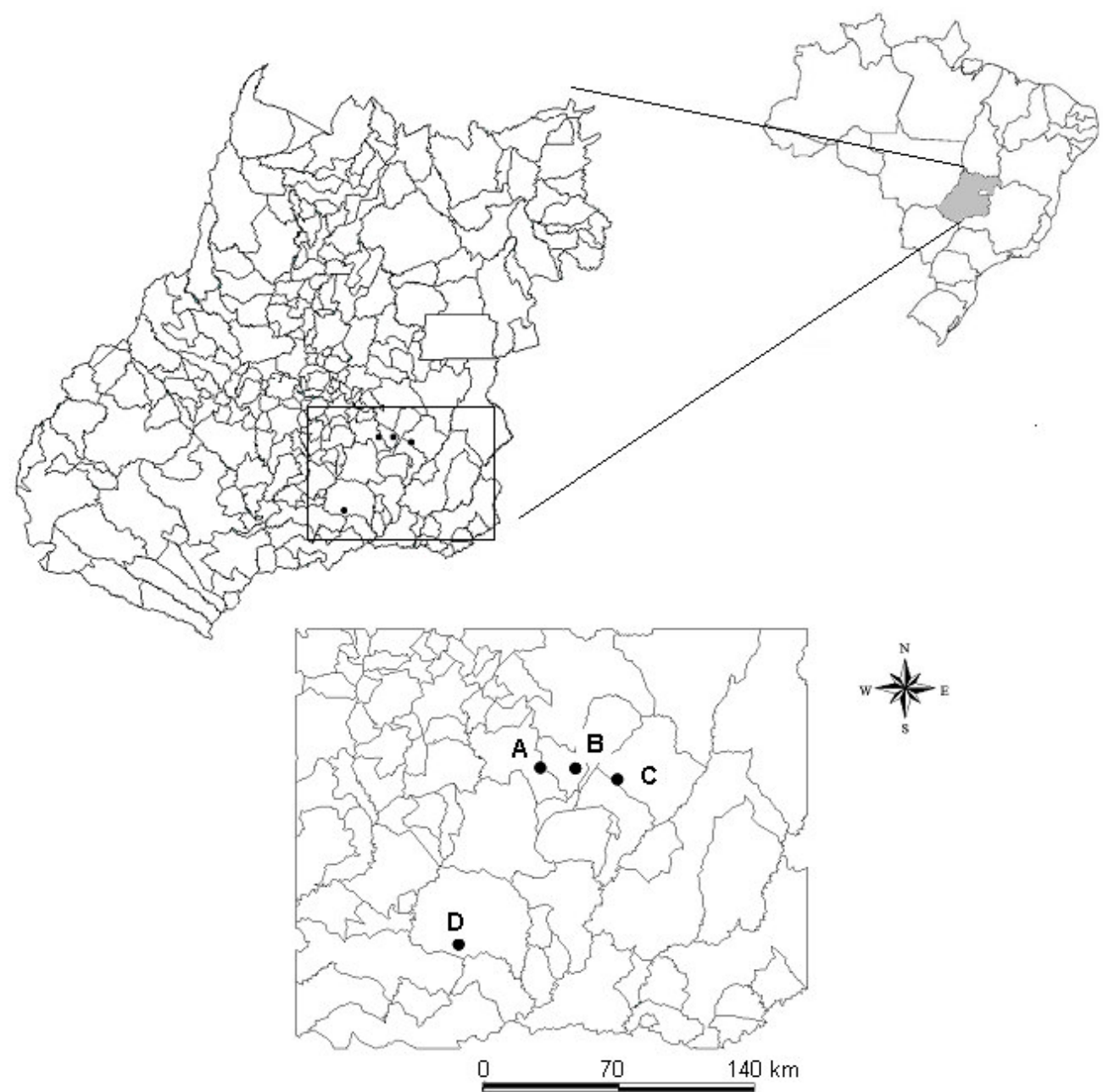

Figura 1 - Região Sudeste do estado de Goiás com os locais de coleta de $S$. lycocarpum demarcados

As áreas da pesquisa apresentam vegetação de cerrado relativamente bem preservado e conexão com outras áreas preservadas próximas ou com matas ciliares, podendo ser consideradas como corredores de fauna, uma vez que permitem o trânsito de animais entre os fragmentos de cerrado presentes em áreas de Reserva Legal e Áreas de Preservação Permanente das fazendas. 


\subsection{Amostragem}

A estratégia de coleta consistiu em percorrer a área de cada um dos fragmentos, coletando-se todos os indivíduos de $S$. lycocarpum avistados até que o número amostral de 60 indivíduos fosse atingido. A coleta de indivíduos situados a menos de $20 \mathrm{~m}$ das margens dos fragmentos foi evitada.

Observou-se, nas quatro áreas de coleta, que os indivíduos de $S$. lycocarpum localizavam-se em locais em que a vegetação de cerrado era menos densa. Nesses ambientes mais abertos foram observados agrupamentos de $S$. lycocarpum cujos indivíduos eram mais vigorosos. Em locais com vegetação de cerradão, apenas raramente eram detectados indivíduos de $S$. lycocarpum, sendo estes em clareiras. A caracterização das fisionomias da vegetação de cerrado, utilizada neste trabalho, se baseou na classificação apresentada por Coutinho (1978). A coleta das folhas das populações A, B e C foi realizada em junho de 2002 e coleta das folhas da população $D$ foi feita em novembro de 2004.

A região em que foi coletada população A (170.'S $48^{\circ} 46^{\prime} \mathrm{W}$ ) apresentava vegetação de cerrado relativamente extensa e contínua, com área de cerca de 500 ha, sendo que o entorno era caracterizado por regiões de pastagens. De modo geral, a vegetação nessa área é heterogênea, consistindo de áreas de cerrado "sensu stricto", com algumas manchas de cerradão com solo pedregoso e ausência de S. Iycocarpum. A população amostral A está distribuída em uma área de 15,3 ha, o que resulta em uma densidade de 3,92 indivíduos/ha.

A região de coleta da população $B\left(17^{\circ} 00^{\prime} S 48^{\circ} 35^{\prime} \mathrm{W}\right)$ foi a que apresentou a vegetação de cerrado menos densa, definida como campo cerrado. Em decorrência da maior luminosidade, a população de $S$. lycocarpum apresentou a maior densidade, sendo que, apenas nessa área, a coleta de folhas de indivíduos muito próximos foi evitada. Os indivíduos apresentavam-se vigorosos, exibindo copas densas e grande quantidade de flores e frutos. $A$ área de cerrado em que a população $B$ foi coletada apresenta cerca de 50 ha, sendo que a população amostral está distribuída em uma área de 12,41 ha. A estimativa de 4,83 indivíduos/ha para essa população está subestimada, uma vez que não foram amostrados todos os indivíduos observados na 
área percorrida. A vegetação de entorno consiste de pastos com algumas árvores e arbustos esparsos.

A área em que foi coletada a população C (17\%03'S $\left.48^{\circ} 22^{\prime} \mathrm{W}\right)$ apresenta cerca de 50 ha, sendo que o aspecto da vegetação era similar à área de coleta da população A, consistindo de cerrado "sensu stricto" com algumas manchas de cerradão, onde as lobeiras eram raras. A estratégia de coleta também foi semelhante sendo que todos os indivíduos observados na área de 4,92 ha foram coletados, resultando em uma densidade de 12,2 indivíduos/ha. Embora o entorno da área seja considerado o mais antrópico, consistindo da rodovia asfaltada GO 219 e extensas plantações de soja/milho, a população não se encontra isolada de áreas de vegetação preservada, sendo que foi registrada a evidência de presença de fauna (fezes de lobo guará contendo sementes de $S$. lycocarpum).

A área em que foi coletada a população D (175' S $\left.49^{\circ} 11^{\prime} \mathrm{W}\right)$ apresenta cerca de 217 ha e vegetação de campo cerrado, com aspecto similar ao observado na população B. Foram coletados todos os indivíduos observados em uma área de 23,11 ha, resultando em uma densidade de 2,50 indivíduos/ha. A região de entorno caracteriza-se por fazendas com pastos e plantações de soja e milho, bem como a rodovia que interliga as cidades de Morrinhos e Buriti Alegre.

Por se tratar de uma espécie heliófila que se desenvolve bem em ambientes alterados, é muito comum o estabelecimento de indivíduos de $S$. lycocarpum nas margens das estradas da região e em pastos. Buscou-se estudar a diversidade genética em plantas situadas na margem da estrada, com o objetivo de inferir sobre a origem das sementes que colonizaram esse ambiente. Para tal, foram coletadas folhas de indivíduos situados na margem da estrada de terra que interliga as populações $A, B$ e C. Amostrou-se um indivíduo a cada quilômetro, totalizando 60 plantas. Nos dois primeiros quilômetros mais próximos às populações o esforço amostral foi maior, sendo que em média foram coletados seis indivíduos nos dois primeiros quilômetros (Figura 2). A localização espacial das árvores foi determinada com a utilização de um aparelho de GPS (e-trex, Garmin ${ }^{\circledR}$ ). 


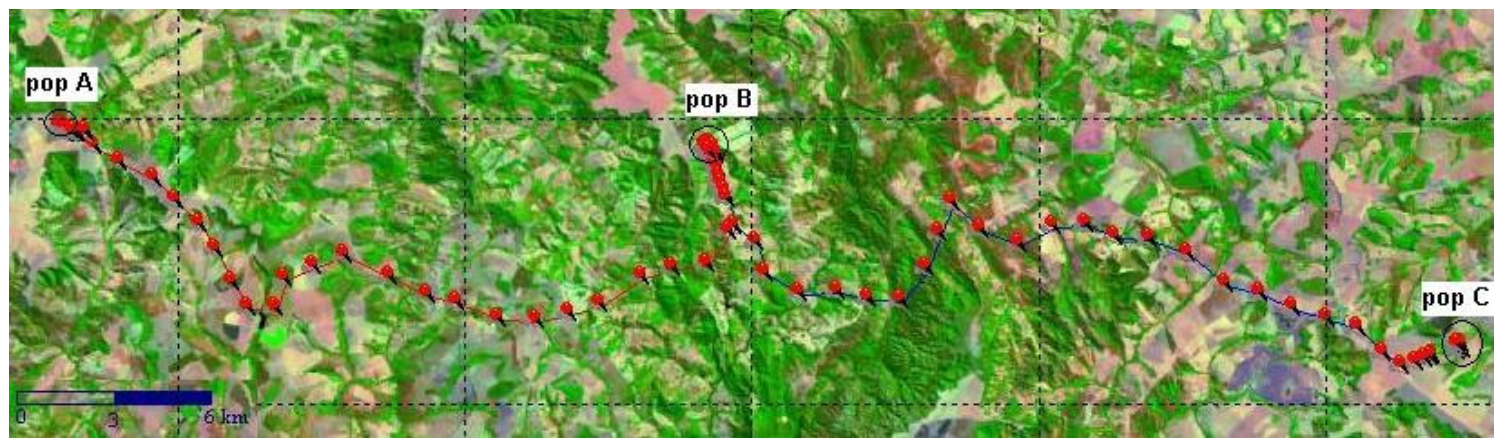

Figura 2 - Distribuição dos indivíduos amostrados na margem da estrada que interliga as populações A, B e C. Cada ponto vermelho indica uma planta de $S$. lycocarpum coletada

O número total de adultos amostrados foi 294 (Tabela 1). Após a coleta, as folhas foram embaladas em sacos de papel identificados com o número da planta de origem, secadas em sílica gel e transportadas ao Laboratório de Reprodução e Genética de Espécies Arbóreas (LARGEA), do Departamento de Ciências Florestais da ESALQ/USP, onde foram armazenadas até o momento da extração de DNA.

Tabela 1. Populações de $S$. Iycocarpum coletadas no Sudeste do estado de Goiás

\begin{tabular}{llccc}
\hline População & Município & $\begin{array}{c}\text { Área total do } \\
\text { fragmento (ha) }\end{array}$ & $\begin{array}{c}\text { Área de coleta } \\
\text { (ha) }\end{array}$ & $\begin{array}{c}\text { Árvores } \\
\text { amostradas }\end{array}$ \\
\hline A & Bela Vista de Goiás & 500 & 15,3 & 58 \\
B & S. Miguel do Passa Quatro & 50 & 12,4 & 60 \\
C & Orizona & 50 & 4,92 & 60 \\
D & Morrinhos & 217 & 23,11 & 56 \\
Margem & & & & 60 \\
Total & & & 294 \\
\hline
\end{tabular}

\subsection{Coleta de sementes e produção das progênies}

A coleta de frutos, com o objetivo de produzir progênies para se estudar 0 sistema de reprodução e o padrão de herança cloroplastidial, foi realizada apenas nas populações A, B e C em 06 de março de 2003. Observou-se que, embora a espécie frutifique durante o ano todo, a quantidade de frutos produzidos é pequena, ou seja, encontram-se poucos indivíduos frutificando em uma mesma época em cada 
população. Adicionalmente, o desenvolvimento do fruto é lento, sendo raro encontrar frutos maduros, uma vez que a procura por esse fruto pela fauna é elevada.

Considerando-se as três populações, coletou-se de um a dois frutos de 24 árvores maternas, totalizando 36 frutos. Após o amadurecimento, que ocorreu gradualmente, as sementes foram retiradas manualmente da polpa carnosa e lavadas em água corrente em uma peneira para retirar a polpa aderida às sementes. Em geral, quando os frutos encontram-se excessivamente maduros, há crescimento de fungos nas sementes, que morrem antes de germinarem. Depois de limpas, as sementes foram imersas em água para embeber durante 24 horas e, em seguida, foram colocadas para germinar em Gerbox sobre papel de filtro e mantidas em câmaras de germinação com temperatura $\left(30-35^{\circ} \mathrm{C}\right)$ e fotoperíodo (oito horas de escuro) controlados.

Dos 36 frutos coletados, 25 amadureceram até 30 dias após a coleta e cinco foram descartados devido à imaturidade do fruto e das sementes. Foram colocadas para germinar 100 sementes de cada fruto em dois Gerbox contendo 50 sementes cada. A germinação ocorreu lentamente. Após atingirem cerca de $10 \mathrm{~cm}$ de comprimento, as plântulas foram transplantadas do Gerbox para recipientes contendo substrato orgânico e mantidas em condições de laboratório, com luminosidade natural e temperatura controlada $\left(24^{\circ} \mathrm{C}\right)$. A extração de DNA foi feita após o desenvolvimento do segundo par de folhas, quando as plântulas atingiam cerca de $10 \mathrm{~cm}$. O número de progênies em cada população foi muito variável; com duas, nove e três árvores maternas nas populações $A, B$ e $C$, respectivamente. $O$ mesmo foi observado com relação ao número de indivíduos por progênie. As sementes das matrizes B1P, B6P e B12P foram obtidas de dois frutos.

\subsection{Procedimento laboratorial}

As análises laboratoriais foram realizadas no Laboratório de Reprodução e Genética de Espécies Arbóreas (LARGEA), localizado no Departamento de Ciências Florestais da ESALQ-USP, em Piracicaba - SP. A extração do DNA genômico total das 
amostras foi realizada seguindo o protocolo CTAB descrito por Ferreira \& Grattapaglia (1998). A metodologia foi otimizada com a retirada dos pêlos que recobrem a superfície das folhas com o auxílio de uma lâmina. Após a quantificação de DNA as amostras foram diluídas em água MiliQ a $5 \mathrm{ng} / \mu \mathrm{l}$.

\subsubsection{Amplificação dos locos microssatélites}

Uma vez que ainda não foram desenvolvidos iniciadores que amplificam regiões de microssatélites para $S$. lycocarpum, optou-se por testar a transferibilidade de iniciadores desenvolvidos para um outro gênero da família Solanaceae, Capsicum. Foram fornecidos pelo Prof. Márcio Elias Ferreira (CENARGEN/EMBRAPA), 206 iniciadores de Capsicum spp desenvolvidos no CENARGEN/EMBRAPA, bem como o protocolo de amplificação via PCR (Reação em Cadeia da Polimerase) e amostras de DNA de Capsicum spp.

O coquetel $(13 \mu \mathrm{l})$ para a realização da PCR foi composto por 15,0 ng de DNA genômico, $250 \mu \mathrm{M}$ de dNTPs, 0,5 $\mu \mathrm{M}$ de $\mathrm{MgCl}_{2}$, tampão para PCR $1 \mathrm{X}$ (10mM de Tris-HCl,

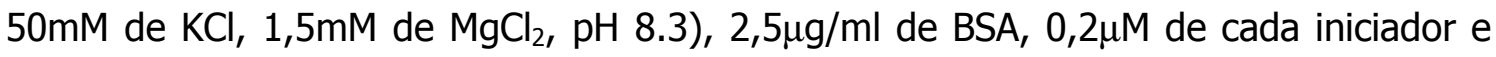
$1 \mathrm{U}$ de Taq DNA polimerase (Phoneutria). As amplificações foram realizadas em termociclador do tipo MJ Research PTC-100 utilizando o seguinte protocolo: $96^{\circ} \mathrm{C}$ por 2 minutos; 30 ciclos de $94^{\circ} \mathrm{C}$ por 1 minuto, temperatura de hibridação específica de cada par de iniciadores por 1 minuto, $72^{\circ} \mathrm{C}$ por 1 minuto e terminando com $72^{\circ} \mathrm{C}$ por 7 minutos.

Após a amplificação, os fragmentos de DNA foram separados em gel desnaturante de poliacrilamida a 4\%, em corrida de uma hora em tampão TBE $1 \mathrm{X}$ em cuba vertical. Os fragmentos foram observados na forma de bandas, após coloração com nitrato de prata, seguindo o protocolo desenvolvido por Creste et al. (2001). o tamanho dos alelos foi determinado por comparação com um marcador de peso molecular padrão (10-pb "ladder" - Invitrogen $($ )). Fragmentos amplificados de diferentes tamanhos foram considerados alelos diferentes.

Foram utilizados seis pares de iniciadores de microssatélites cloroplastidiais desenvolvidos para angiospermas dicotiledôneas por Weising \& Gardner (1999). As 
condições de amplificação, eletroforese e interpretação dos locos foram semelhantes ao realizado para microssatélites nucleares.

\subsection{Análise estatística}

\subsubsection{Teste do Equilíbrio de Hardy-Weinberg}

Desvios das proporções de Hardy-Weinberg em cada loco microssatélite nuclear em todas as populações foram avaliados por meio do teste exato de Fisher com uso do programa GDA (Lewis \& Zaykin, 2001), como descrito em Weir (1996). As probabilidades exatas menores que o nível de significância $(\alpha=0,05$ ou 0,01$)$ indicam desvios significativos nas proporções de Hardy-Weinberg.

\subsubsection{Desequilíbrio genotípico entre pares de locos}

O desequilíbrio genotípico entre pares de locos foi avaliado por meio do teste de razão de probabilidade (Estatística G), como descrito em Weir (1996), com uso do programa $F_{\text {STAT }}$ (Goudet, 1995), para marcadores microssatélites nucleares e cloroplastidiais. Por esse procedimento, genótipos de dois locos são associados diversas vezes e a estatística é recalculada no novo conjunto de dados.

A probabilidade (valor do $p$ ) é estimada como a proporção das estatísticas obtidas nos conjuntos de dados aleatorizados que é maior ou igual ao observado. 0 número de aleatorizações é fixado pelo nível de significância escolhido $(\alpha=0,01)$, bem como pelo número de indivíduos e locos.

Qualquer associação encontrada entre as freqüências gênicas em locos diferentes é geralmente denominada como desequilíbrio de ligação, mesmo quando as associações não são decorrentes de ligação entre os locos (Weir, 1996). Para locos nucleares, pressupõe-se que os locos são independentes e, portanto, a associação entre pares de locos não é esperada. No entanto, para locos cloroplastidiais, presumese que os locos não são independentes. O genoma do cloroplasto é haplóide e herdado sem recombinação, logo se espera associação significativa entre pares de locos. 


\subsubsection{Teste da herança do cloroplasto}

A probabilidade de transmissão paterna do cloroplasto foi estimada com os genótipos obtidos das progênies coletadas nas populações $A, B$ e C. Utilizou-se o procedimento descrito em Milligan (1992), para estimar a probabilidade de transmissão paterna do cloroplasto $(P)$, separadamente para as progênies coletadas nas populações A, B e C. A probabilidade de observar $K$ progênies contendo organelas derivadas do pai em conjunto de $N$ progênies é dada pela distribuição binomial:

$$
\operatorname{Pr}(K / N, P)=\frac{N !}{K !(N-K) !} P^{K}(1-P)^{N-K}
$$

A equação fornece a probabilidade, dado um determinado tamanho amostral, de reconhecer herança paterna, quando a taxa de transmissão é dada por $P$. O poder do teste de hipótese $(\beta)$ deve ser grande o suficiente para assegurar que a hipótese de herança estritamente materna não seja falsamente aceita. Foi considerado o poder do teste $\beta \geq 0,95$. Como $\beta=1-\operatorname{Pr}(K / N, P)$, o valor de $\beta$ foi substituído na equação (1).

Em progênies de polinização aberta, apenas um subconjunto das progênies é informativo. Isso porque pode ocorrer autofecundação e mesmo que as sementes sejam resultantes de fecundação cruzada, o pai pode ter o mesmo haplótipo da mãe (Oddou-Muratorio et al., 2001). O número de cruzamentos informativos $\left(N_{\text {inf }}\right)$, aqueles em que os dois parentais são esperados por carregar haplótipos diferentes, assumindo cruzamentos aleatórios é estimado por:

$$
N_{\text {inf }}=\sum_{i} N\left(1-p_{i}\right)(1-\hat{s})
$$


Em que $p_{i}$ é a freqüência do haplótipo $i$ na população, $\hat{s}$ é a taxa de autofecundação e $N$ é o número de plântulas com o haplótipo $i$. Substituiu-se $N$ por $N_{\text {inf }}$ na eq. (1), como sugerido por Oddou-Muratorio et al. (2001).

\subsubsection{Diversidade genética intrapopulacional}

Para os marcadores microssatélites nucleares, as freqüências alélicas foram estimadas por: $\hat{p}_{i j}=n_{i j} / n_{. j}$, em que $\hat{p}_{i j}=$ freqüência do alelo $i$ na população $j$; $n_{i j}=$ número de ocorrências do alelo $i$ na população $j ; n_{. j}=$ número total de alelos amostrados na população $j$; com uso do programa $\mathrm{F}_{\text {STAT }}$ (Goudet, 1995).

A diversidade genética dentro das populações foi analisada pela heterozigosidade observada $\left(\hat{H}_{o}\right)$, diversidade gênica $\left(\hat{H}_{e}\right)$, número médio de alelos por loco $(\hat{A})$, número efetivo de alelos por loco $\left(\hat{A}_{e}=1 / \sum p_{i}^{2}\right)$ e índice de fixação de Wright $(\hat{f})$, estimativas obtidas a partir do programa GDA (Lewis \& Zaykin, 2001).

Uma vez que os polimorfismos do genoma do cloroplasto são herdados sem recombinação, cada combinação alélica única entre os seis locos microssatélites foi considerada um haplótipo. Cada haplótipo, por sua vez, é analisado como um alelo diferente de um único loco haplóide. Foram computados o número de haplótipos $\left(\hat{n}_{h}\right)$, a quantidade de haplótipos privados por população $\left(\hat{n}_{p}\right)$ e a proporção de alelos privados $\left(\hat{n}_{p} / \hat{n}_{h}\right)$. As freqüências dos haplótipos em cada população e nos indivíduos amostrados na margem da estrada foram utilizadas para estimar (a) a diversidade haplotípica $\left(h=\left[n_{k} /\left(n_{k}-1\right)\right]\left(1-\sum_{i}^{n} p_{i}^{2}\right)\right)$; em que $n_{k}$ é o número de indivíduos na população $k, p_{i}$ é a freqüência do $i$-ésimo haplótipo e (b) o número efetivo de haplótipos $\left(n_{e}=1 / \sum p_{i .}^{2}\right)$. 


\subsubsection{Correlação espacial dos genótipos}

A autocorrelação espacial multialélica foi obtida para as populações A, B, C e D com os dados de ambos os marcadores. Distâncias genéticas entre pares de indivíduos foram calculadas como descrito em Smouse \& Peakall (1999). Utilizou-se o procedimento de manter constante o número de indivíduos conectados em cada classe, tornando as correlações em cada classe de distância comparáveis, e com erros de estimativa semelhantes. Por essa abordagem, estabeleceu-se o número de classes de distância (11), porém o tamanho de cada classe foi variável e estabelecido de acordo com o número de pares de indivíduos conectados em cada classe. Essa estratégia é a mais adequada quando os indivíduos estão distribuídos de forma irregular na área, como ocorre nas populações de $S$. lycocarpum. O coeficiente de correlação obtido tem interpretação análoga ao coeficiente de correlação de Pearson, o valor zero indica que não há autocorrelação e o coeficiente varia entre $-1,0$ e $+1,0$, sendo seus máximos para autocorrelações negativas e positivas. Os intervalos de confiança a $95 \%$ foram obtidos por 999 permutações. Os valores de correlação fora do intervalo de confiança são considerados estatisticamente significativos. $O$ fato de o correlograma apresentar um ou mais coeficientes significativos não indica que o correlograma como um todo seja significativo, ou seja, represente efetivamente um padrão espacial. Para que correlograma como um todo seja significativo a $5 \%$, pelo menos uma das correlações deve ser significativa no nível de $0,05 / k$, em que $k$ é número de classes de distância (Diniz-Filho, 1997). A correlação espacial multialélica foi realizada com uso do programa GenAIEx V5 (Peakall \& Smouse, 2001).

\subsubsection{Coeficiente de coancestralidade}

Com o objetivo de complementar a análise da distribuição espacial dos genótipos nas populações, buscou-se avaliar a coancestralidade média entre pares de indivíduos nas populações naturais. Como a genealogia entre os indivíduos amostrados nas populações naturais não é conhecida, estimou-se inicialmente o coeficiente de 
parentesco com o uso de genótipos moleculares dos locos SSR nucleares, como descrito por Lynch \& Ritland (1999). O estimador descrito por esses autores é o mais adequado para cálculo de parentesco em organismos diplóides e populações não endogâmicas em Equilíbrio de Hardy-Weinberg.

Considerando que o indivíduo de referência possui os alelos $a$ e $b$ e o outro indivíduo do par os alelos $c$ e $d$, e sendo $p_{a}$ e $p_{b}$ as freqüências dos alelos $a$ e $b$ do loco $l$ na população, o estimador geral para o coeficiente de parentesco é dado por:

$$
\hat{r}_{x y}(l)=\frac{p_{a}\left(S_{b c}+S_{b d}\right)+p_{b}\left(S_{a c}+S_{a d}\right)-4 p_{a} p_{b}}{\left(1+S_{a b}\right)\left(p_{a}+p_{b}\right)-4 p_{a} p_{b}}
$$

Sendo que se o indivíduo de referência for homozigótico, $S_{a b}=1$, enquanto se for heterozigótico $S_{a b}=0$. Se o alelo $a$ do indivíduo de referência for idêntico ao alelo $c$ do outro indivíduo do par, $S_{a c}=1$ e se for diferente, $S_{a c}=0$. Segue-se o mesmo raciocínio para as demais combinações $\left(S_{b c}, S_{b d}\right.$ e $\left.S_{a d}\right)$. De acordo com a suposição de que os locos são independentes (estão em equilíbrio de ligação), obtém-se o coeficiente de parentesco para cada loco por meio da média aritmética das estimativas recíprocas $\hat{r}_{x y}$ e $\hat{r}_{y x}$. De acordo com Lynch \& Ritland (1999), estimativas recíprocas apresentam menor variância estatística do que uma única estimativa.

Estimativas multiloco do coeficiente de parentesco são obtidas por meio da média das estimativas dos $l$ locos, ponderada pelos pesos específicos de cada loco. Sendo $w_{r, x}(l)$ o peso usado para os $l$ locos e $W_{r, x}$ a soma dos pesos de todos os $L$ locos, a estimativa multiloco do coeficiente de parentesco entre $x$ e $y$ é dada pela eq. (4):

$$
\hat{r}_{x y}=\frac{1}{W_{r, x}} \sum_{l=1}^{L} w_{r, x}(l) \hat{r}_{x y}(l)
$$


A ponderação pelo peso de cada loco é necessária para minimizar a variância amostral das estimativas médias. A variância entre locos pode ser resultante tanto da variação entre os genótipos de referência (diferença na freqüência de indivíduos homozigóticos e heterozigóticos na população), como da variação nos níveis de polimorfismo (locos com mais alelos são mais informativos).

Os pesos de cada loco $l$ são dados pelo inverso da variância amostral das estimativas de parentesco de acordo com a eq. (5).

$$
w_{r, x}(l)=\frac{1}{\operatorname{Var}\left[\hat{r}_{x y}(l)\right]}=\frac{\left(1+S_{a b}\right)\left(p_{a}+p_{b}\right)-4 p_{a} p_{b}}{2 p_{a} p_{b}}
$$

As estimativas do coeficiente de parentesco foram obtidas com o uso do programa computacional SPAGeDiversão 1.1 (Hardy \& Vekemans, 2002).

Como o coeficiente de parentesco estimado pelo método de Lynch \& Ritland (1999) refere-se ao parentesco definido por Wright (1922), dividiu-se a estimativa calculada pelo SPAGeDi por dois, obtendo o coeficiente de coancestralidade $\left(\theta_{x y}\right)$. Os valores esperados do coeficiente de coancestralidade para pares de indivíduos com genealogia conhecida em populações panmíticas são: 1,0 entre irmãos de linhas puras; 0,50 entre irmãos clonais e entre irmãos de autofecundação; 0,25 entre irmãos completos e entre mãe e filho e; 0,125 entre meios-irmãos.

O coeficiente de coancestralidade de cada população foi obtido pela média aritmética entre os coeficientes estimados para todos os pares de indivíduos da população. Em seguida, obteve-se a coancestralidade média em grupos préestabelecidos de pares de indivíduos. Três grupos foram formados com base na semelhança dos genótipos nucleares e cloroplastidiais entre os indivíduos:

1) Grupo ID: pares de indivíduos com genótipos nucleares e cloroplastidiais idênticos;

2) Grupo LM: pares de indivíduos com genótipos cloroplastidiais idênticos e genótipos nucleares distintos e; 
3) Grupo NP: pares de indivíduos com genótipos nucleares e cloroplastidiais distintos.

A coancestralidade média estimada para cada grupo foi comparada com os valores de referência citados anteriormente. A pressuposição é que a coancestralidade média obtida para o grupo ID seja próxima ao esperado para irmãos clonais $(0,5)$ e que a coancestralidade do grupo LM seja superior ao do grupo NP. Isso porque os indivíduos com genótipos cloroplastidiais idênticos (grupo LM) possuem pelo menos um ancestral materno em comum, sendo esses mais semelhantes do que aqueles com genótipos nucleares e cloroplastidiais distintos (grupo NP).

Com o objetivo de validar as estimativas de coancestralidade calculadas para os indivíduos adultos, calculou-se a coancestralidade média das progênies obtidas nas populações $A, B$ e C. Como as progênies são de polinização aberta, espera-se que a coancestralidade seja próxima a de meios-irmãos $(0,125)$.

\subsubsection{Estrutura genética}

A estrutura genética foi caracterizada pela análise da variância das freqüências alélicas (Weir, 1996), sendo consideradas as populações A, B, C e D. Os parâmetros estimados para os microssatélites nucleares foram: índice médio de fixação dentro das populações $(\hat{f})$; índice de fixação total das populações $(\hat{F})$ e divergência genética entre populações $\left(\hat{\theta}_{p}\right)$. Estimou-se o intervalo de confiança a $99 \%$ de probabilidade pelo método de reamostragem "bootstrap", utilizando-se 10.000 repetições sobre locos. Os parâmetros relacionados acima foram estimados com o auxílio do programa GDA (Lewis \& Zaykin, 2001). O parâmetro $\hat{R}_{S T}$, mais adequado para estimação da divergência genética entre as populações quando se utilizam marcadores microssatélites, foi estimado com uso do programa RSTCalc (Goodman, 1997).

Para os marcadores cloroplastidiais, a estrutura genética foi caracterizada pela metodologia de Nei, sendo consideradas as populações A, B, C e D. Foram estimadas a diversidade média intrapopulacional $\left(\hat{H}_{S}\right)$, diversidade total $\left(\hat{H}_{T}\right)$ e diferenciação 
genética entre populações $\left(\hat{G}_{S T}\right)$ com uso do programa $\mathrm{F}_{\mathrm{STAT}}$ (Goudet, 1995). Realizouse a análise da variância das freqüências alélicas (Weir, 1996) para estimação da divergência genética entre populações $\left(\hat{\theta}_{p C}\right) . F$ e $f$ não são definidos para genomas haplóides. A estimativa de $\hat{\theta}_{p C}$ e o desvio padrão, obtido por 10.000 reamostragens "bootstrap" sobre populações, foram calculados com uso do programa EG (Coelho, 2000).

\subsubsection{Fluxo gênico}

O fluxo gênico $(\mathrm{Nm}$ ) foi calculado pela abordagem indireta a partir dos valores estimados de $\hat{F}_{S T}$ (diversidade genética entre populações obtida com marcadores nucleares). O fluxo gênico com microssatélites nucleares foi calculado de acordo com o modelo proposto por Wright (1951).

$$
N m=\frac{1}{4}\left(\frac{1}{\hat{F}_{S T}}-1\right)
$$

Substituiu-se $\hat{F}_{S T}$ por $\hat{\theta}_{p}$ na eq. (6), conforme sugerem Cockerham e Weir (1993), para uma estimação de fluxo gênico não viesada. O fluxo gênico com marcadores cloroplastidiais foi calculado como proposto por McCauley (1995):

$$
N m=\frac{1}{2}\left(\frac{1}{\hat{\theta}_{p c}}-1\right)
$$

$\mathrm{Na}$ eq.(7), $\hat{\theta}_{p_{C}}$ é a divergência genética calculada com marcadores cloroplastidiais. 
A relação inversa entre $F_{S T}$ e $N m$ assume que os marcadores são neutros, as populações estão arranjadas de acordo com o modelo de ilhas e que foi atingido o equilíbrio entre deriva genética e migração. Entretanto, como discutido por Slatkin \& Barton (1989), há evidências que essa relação não é fortemente afetada por desvios no modelo de ilhas. No caso dos marcadores cloroplastidiais pressupõe-se que a herança do genoma do cloroplasto é estritamente materna e também que não há heteroplasmia (Ennos, 1994).

A razão de migração de pólen e sementes foi calculada de acordo com Ennos (1994):

$$
\frac{m_{p}}{m_{s}}=\frac{\left(\frac{1}{F_{S T_{N}}}-1\right)-2 \times\left(\frac{1}{F_{S T_{C}}}-1\right)}{\left(\frac{1}{F_{S T_{C}}}-1\right)}
$$

Na eq. (8), $m_{p}=$ migração de pólen; $m_{s}=$ migração de sementes; $F_{S T_{C}}=$ $F_{S T}$ obtido por marcadores cloroplastidiais; $F_{S T_{N}}=F_{S T}$ calculado por marcadores nucleares.

A razão de fluxo gênico foi também calculada entre pares de populações com o objetivo de avaliar a contribuição relativa de migração de pólen e semente em diferentes escalas geográficas.

\subsubsection{Teste do isolamento pela distância}

Para avaliar se o fluxo gênico em andamento resulta em um padrão de isolamento pela distância, ou seja, se as populações de $S$. lycocarpum estão conectadas por fluxo gênico atual, utilizou-se o procedimento descrito por Slatkin (1993). A abordagem baseia-se na relação linear entre os logaritmos de fluxo gênico $(\mathrm{Nm})$ e distância geográfica. Como discutido por Strand et al. (1996), no contexto do isolamento pela distância e um modelo de alpondras ("stteping-stone") de fluxo gênico, 
uma forte correlação negativa indica que as populações estão em equilíbrio e que o fluxo gênico atual resulta em um padrão de isolamento pela distância, em que a diferenciação genética entre as populações aumenta com a distância geográfica. A ausência de correlação sugere que a indicação de fluxo gênico atual resulta mais da associação histórica entre as populações do que o fluxo gênico interpopulacional corrente.

As estimativas de $\hat{F}_{S T}$ para cada par de populações, obtidas com uso do programa $F_{\text {STAT }}$ (Goudet, 1995), foram utilizadas para calcular o fluxo gênico entre pares de populações $(\hat{M})$. A significância da correlação entre o logaritmo da distância geográfica entre pares de populações e o logaritmo do fluxo gênico entre elas foi avaliada por meio da estatística Z de Mantel (Mantel, 1967), utilizando-se 1.000 permutações, com uso do programa NTSYS-pc (Rohlf, 1989). O teste de isolamento pela distância foi realizado com os genótipos nucleares e cloroplastidiais.

\subsubsection{Colonização na margem da estrada}

\subsubsection{Teste de maternidade}

Partindo-se da pressuposição de que as margens de estradas foram colonizadas por sementes trazidas das populações naturais adjacentes, buscou-se inferir sobre a procedência dos indivíduos que ocuparam a margem da estrada que interliga as populações A, B e C. Para identificar a origem materna das sementes que colonizaram a margem da estrada, foram utilizadas as freqüências alélicas dos locos microssatélites nucleares e cloroplastidiais. Em decorrência da análise combinada dos dois marcadores, utilizou-se o termo teste de maternidade em contraposição aos usuais testes de paternidade apresentados na literatura. Na descrição da metodologia, entretanto, será utilizado o termo correntemente utilizado de teste de paternidade.

Foi utilizado o método de máxima probabilidade com base na comparação dos genótipos dos adultos amostrados nas populações naturais A, B e C com cada um dos indivíduos amostrados na margem da estrada. Para cada provável filho, a probabilidade de paternidade de cada candidato a pai foi medida usando o logaritmo de uma razão de probabilidades (o "LOD-score"), como definido por Meagher (1986). A razão de 
probabilidade equaciona a probabilidade de paternidade do suposto pai com a probabilidade de paternidade de outros indivíduos alternativos. Um "LOD-score" de valor positivo implica que o suposto pai tem maior probabilidade de paternidade que qualquer outro indivíduo escolhido aleatoriamente na população. A comprovação da paternidade é feita com uso da estatística $\Delta$, a diferença em "LOD-score" entre o primeiro mais provável pai (com o maior "LOD-score") e o segundo (com o segundo maior "LOD-score"). A confiabilidade da inferência paterna é feita por meio da comparação do valor do $\Delta$ com um valor crítico $\left(\Delta_{C}\right)$ abaixo do qual a paternidade não pode ser atribuída a um determinado nível de significância. $\Delta_{C}$ é obtido por meio de uma simulação como apresentado por Marshall et al. (1998).

As freqüências alélicas foram estimadas com 0 auxílio do programa $F_{\text {STAT }}$ (Goudet, 1995). A simulação e os testes de partenidade (estimação dos "LOD-scores") foram realizados com uso do programa CERVUS 2.0 (Marshall et al., 1998).

\subsubsection{Distâncias genéticas}

Com o objetivo de analisar mais detalhadamente a contribuição relativa das populações $A, B$ e $C$ na colonização da margem da estrada que as interligam, consideraram-se esses indivíduos como um único grupo e estimou-se a distância genética de Nei (1972) entre os pares, obtida com os haplótipos cloroplastidiais. A estrutura genética foi visualizada por meio de dendrograma construído a partir das distâncias genéticas utilizando o critério de agrupamento UPGMA.

\subsubsection{Sistema de Reprodução}

Para inferir sobre o sistema de reprodução a partir das freqüências genotípicas, utilizou-se o modelo misto de reprodução de Ritland \& Jain (1981) cujas pressuposições são: 1) os eventos reprodutivos são aleatórios, ou seja, que o cruzamento (com probabilidade $t$ ) ou autofecundação $(s=1-t)$ ocorrem ao acaso; 2 ) a probabilidade de cruzamento é independente do genótipo materno; 3) o conjunto de pólen é homogêneo para todas as árvores maternas; 4) os alelos de diferentes locos segregam 
independentemente e; 5) os locos avaliados não sofreram seleção ou mutação entre o evento reprodutivo e a análise dos indivíduos (Ritland \& Jain, 1981).

O programa MLTR V. 2.4 (Ritland, 2002) foi utilizado para obter as estimativas de: 1) a taxa populacional de cruzamento multiloco $\left(\hat{t}_{m}\right)$, pelo método de Máxima Verossimilhança; 2) a taxa populacional de cruzamento uniloco $\left.\left(\hat{t}_{s}\right) ; 3\right)$ a taxa de cruzamento biparental ou cruzamento entre parentes $\left.\left(\hat{t}_{m}-\hat{t}_{s}\right) ; 4\right)$ as freqüências alélicas dos óvulos e do pólen $(o$ e $p), 6)$ a correlação de paternidade uniloco $\left(\hat{r}_{p}\right)$ e 7) a correlação de auto-fecundação $\left(\hat{r}_{s}\right)$. O tamanho de vizinhança, ou número médio de doadores de pólen, foi estimado por $1 / \hat{r}_{p}$. Os erros-padrão foram obtidos por meio de 500 "bootstraps" sobre famílias.

O coeficiente de correlação de parentesco $\left(r_{x y}\right)$ entre plantas dentro de progênies foi estimado conforme Ritland (1989):

$$
\hat{r}_{x y}=0,25\left(1+\hat{F}_{m}\right)\left[4 \hat{s}+\left(\hat{t}_{m}^{2}+\hat{s}_{m} \hat{r}_{s}\right)\left(1+\hat{r}_{p}\right)\right]
$$

Sendo que na eq. (9), $\hat{F}_{m}$ é o coeficiente de endogamia da geração parental, $\hat{s}$ é a taxa de autofecundação $\left(1-\hat{t}_{m}\right)$, e os demais parâmetros foram definidos anteriormente.

O teste de cruzamentos aleatórios foi avaliado pelo teste de Equilíbrio de HardyWeinberg nas árvores maternas e nas progênies por meio do teste exato de Fisher, com uso do programa GDA (Lewis \& Zaykin, 2001). A homogeneidade entre as freqüências alélicas dos conjuntos de óvulos e pólen foi avaliada pela estimativa de $\hat{F}_{S T}$ (Nei, 1977), como uma medida de divergência genética entre freqüências alélicas de grupos distintos. A significância de $\hat{F}_{S T}$ para cada loco foi testada pelo método do quiquadrado proposto por Workman \& Niswander (1970), eq. (10):

$$
\chi^{2}=2 n F_{S T}(k-1) \quad \mathrm{GL}=(k-1)(s-1)
$$


Na eq. (10), $n=$ número de indivíduos nos dois grupos, $k=$ número de alelos e $s=$ número de grupos.

Os índices de fixação para adultos $(\hat{F})$ e progênies $\left(\hat{F}_{p}\right)$ e seus respectivos intervalos de confiança foram obtidos por 10.000 reamostragens "bootstrap", com uso do programa GDA (Lewis \& Zaykin, 2001).

\subsubsection{Estimadores para estratégias de conservação}

\subsubsection{1 Área mínima viável para conservação in situ}

O tamanho efetivo populacional $\left(\hat{N}_{e}\right)$ foi calculado com base no valor do índice de fixação $(\hat{f})$ estimado para cada população de acordo com o equação apresentada por Vencovsky \& Crossa (1999):

$$
\hat{N}_{e}=\frac{n}{1+\hat{f}}
$$

Na eq. (11), $n$ é o número de indivíduos amostrados.

O tamanho efetivo populacional $\left(\hat{N}_{e}\right)$, o tamanho efetivo de referência $\left(\hat{N}_{e(r e f)}\right)$, a densidade populacional $(d)$ e o número amostral $(n)$ foram considerados para cálculo da área mínima viável ( $A M V$ ) para conservação genética in situ das quatro populações naturais estudadas. Utilizou-se a expressão apresentada por Sebbenn et al. (2003):

$$
A M V=\frac{n \hat{N}_{e(r e f)}}{d \hat{N}_{e}}
$$


Considerou-se o valor de 1.000 para tamanho efetivo de referência $\left(\hat{N}_{e(r e f)}\right)$ apresentado na eq. (12). De acordo com Lynch (1996), a variância genética média (decorrente da deriva genética) torna-se independente do tamanho populacional quando o tamanho efetivo excede 1000 indivíduos, sendo esse limite o mais adequado para a conservação em longo prazo. O limite de 500 para tamanho efetivo proposto por Franklin (1980) também foi considerado.

\subsubsection{Número de populações a serem conservadas}

O número de populações que devem ser conservadas para reter um tamanho efetivo de 500 foi estimado de acordo com o demonstrado por Vencovsky \& Crossa (1999). Como $S$. lycocarpum é uma espécie que ocupa praticamente toda a extensão da área de estudo, pode-se considerar o número de populações na região como infinito. Dessa forma, o número de populações que devem ser conservadas $(S)$ é dependente apenas do valor do $\hat{\theta}_{p}$, ou seja, da divergência genética entre as populações:

$$
N_{e(r e f)}=\frac{S}{2 \times \hat{\theta}_{p}}
$$

\subsubsection{Número de matrizes para coleta de sementes}

Em espécies diplóides, na ausência de endogamia, o coeficiente de parentesco $\left(\hat{r}_{x y}\right)$, definido anteriormente (eq. 9), é o dobro do coeficiente de coancestralidade $(\hat{\theta})$, ou seja, $\hat{\theta}=\hat{r}_{x y} / 2$. Como demonstrado por Cockerham (1969), com o coeficiente de coancestralidade é possível estimar o tamanho efetivo de variância $\left(\hat{N}_{e(v)}\right)$ de uma progênie (eq.14): 


$$
\hat{N}_{e(v)}=\frac{0,5}{\hat{\theta}\left(\frac{n-1}{n}\right)+\frac{1+\hat{F}_{p}}{2 n}}
$$

$\mathrm{Na}$ eq. (14), $n$ corresponde ao tamanho amostral (número de plantas por progênie) e $\hat{F}_{p}$ é o índice de fixação nas progênies.

O valor teórico máximo do tamanho efetivo de variância esperado em uma progênie de uma população ideal (tamanho infinito, sob panmixia, sem a ocorrência de seleção, mutação e migração) é aproximadamente quatro. Com as estimativas do tamanho efetivo de variância $\left(N_{e(v)}\right)$, estimou-se o número de matrizes necessárias para reter um tamanho efetivo $\left(N_{e(r e f)}\right)$ igual a 100 sendo este número calculado pela divisão $N_{e(r e f)} / N_{e(v)}$, como apresentado por Sebbenn (2003). Frankel \& Soulé (1981) propuseram que o tamanho efetivo de 50 seria suficiente para manter o coeficiente de endogamia a uma taxa de 1\% por geração, até dez gerações, em locos com dois alelos, em populações sem sobreposição de gerações. Como $S$. lycocarpum é uma espécie arbórea perene, provavelmente há sobreposição de gerações nas populações e por isso optou-se pelo uso do tamanho efetivo de 100. O tamanho efetivo de 500 também foi considerado para conservação em longo prazo. 


\section{RESULTADOS}

\subsection{Amplificação heterológa dos locos microssatélites nucleares}

Dos 206 iniciadores de Capsicum spp testados, 17 geraram fragmentos em $S$. lycocarpum, ou seja, 8,29\% de transferência. Sardagna et al. (2001) testaram a amplificação heterológa de 141 desses iniciadores em duas espécies de Lycopersicon e a transferência foi de cerca de $18 \%$. Os autores testaram os iniciadores transferidos para essas espécies em outras espécies da família Solanacae e concluíram que as regiões flanqueadoras dos locos microssatélites são conservados nessa família.

Dos 17 locos que amplificaram em $S$. lycocarpum, foram selecionados para síntese doze pares de iniciadores que apresentaram fragmentos mais consistentes e indícios de polimorfismo (CA13, CA23, CA53, CA57, CA58, CA131, CA144, CA161, CA201, CA239 e CA250). O teste em número maior de indivíduos mostrou que apenas os locos CA158 e CA250 apresentaram considerável quantidade de alelos. Porém, após comparação das seqüências desses iniciadores, constatou-se que amplificam o mesmo loco. Devido a isso, o loco CA250 foi descartado. Os locos CA23, CA53, CA144 e CA161 geraram fragmentos passíveis de interpretação, mas o número de alelos/loco foi muito reduzido. O loco CA88 apresentou-se monomórfico para todas as populações. Os pares de iniciadores CA13, CA57, CA131, CA201 e CA239 não geraram locos passíveis de interpretação devido à ocorrência de amplificações não específicas. O presente estudo foi realizado com a utilização de seis locos microssatélites nucleares (Tabela 2). 
Tabela 2. Locos de microssatélites nucleares com as temperaturas de hibridação $\left(T_{m}\right)$, seqüência dos iniciadores, motivos e amplitudes alélicas em pares de base

\begin{tabular}{|c|c|c|c|c|}
\hline Locos & $\mathrm{T}_{\mathrm{m}}\left({ }^{\circ} \mathrm{C}\right)$ & Seqüência dos iniciadores $\left(5^{\prime}-3^{\prime}\right)$ & Motivo* & $\begin{array}{l}\text { Amplitude } \\
\text { alélica (pb) }\end{array}$ \\
\hline \multirow{2}{*}{ CA 23} & \multirow{2}{*}{56} & ggCTCCTAggTATgCACCAg & \multirow[t]{2}{*}{$(\mathrm{TC})_{31}$} & \multirow[t]{2}{*}{$100-102$} \\
\hline & & AATgTgATgCACAgTgCACC & & \\
\hline \multirow{2}{*}{ CA 53} & \multirow{2}{*}{56} & CgACCTTCAggACAgATCAT & \multirow[t]{2}{*}{$(\mathrm{TC})_{25}$} & \multirow[t]{2}{*}{$190-194$} \\
\hline & & CTggTAACCTAgAAAggCAg & & \\
\hline \multirow{2}{*}{ CA 88} & \multirow{2}{*}{54} & AATggATgTTCCСTTgCTाT & \multirow[t]{2}{*}{$(A G)_{22}$} & \multirow[t]{2}{*}{140} \\
\hline & & CAACTgATCAACCATTCCgT & & \\
\hline \multirow{2}{*}{ CA 144} & \multirow{2}{*}{54} & TAgAAACACAAAATgTCCCC & $(\mathrm{GT})_{5}$ & \multirow[t]{2}{*}{$86-88$} \\
\hline & & CCATTgACAAggACAАТTCT & $(\mathrm{GA})_{21}$ & \\
\hline \multirow{2}{*}{ CA 158} & \multirow{2}{*}{56} & CATgCACgTACAACCTgTाT & $(G A)_{32}$ & \multirow[t]{2}{*}{$198-250$} \\
\hline & & TAgTTCCCTTgCTgCAgTAA & & \\
\hline \multirow{2}{*}{ CA 161} & \multirow{2}{*}{54} & CAggTACgTgCTgCTATCAA & $(\mathrm{GA})_{27}$ & \multirow[t]{2}{*}{$174-186$} \\
\hline & & TTggTAAgAAggCCTggTAA & & \\
\hline
\end{tabular}

* Motivos observados em Capsicum

\subsection{Caracterização dos locos}

\subsubsection{Marcadores microssatélites nucleares}

Os indivíduos das quatro populações naturais e os indivíduos coletados na margem da estrada foram estudados com seis locos de microssatélites nucleares. Foram observados 30 alelos. O polimorfismo foi muito reduzido, para a maioria dos locos, sendo que apenas o loco CA158 apresentou número elevado de alelos (17), como esperado para marcadores microssatélites (Figura 3). Embora se tenha observado, nas informações fornecidas juntamente com as seqüências dos iniciadores, que os locos CA23, CA53, CA88 e CA144 já apresentam pequeno número de alelos em Capsicum spp - exibindo sete, cinco, sete e seis alelos, respectivamente - acredita-se que o baixo polimorfismo em $S$. lycocarpum seja devido ao fato desses iniciadores terem sido desenvolvidos para outro gênero (Capsicum spp). 


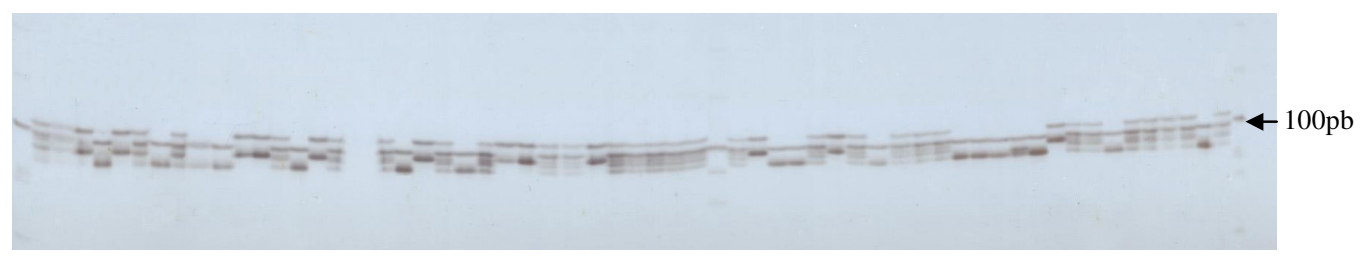

(a)

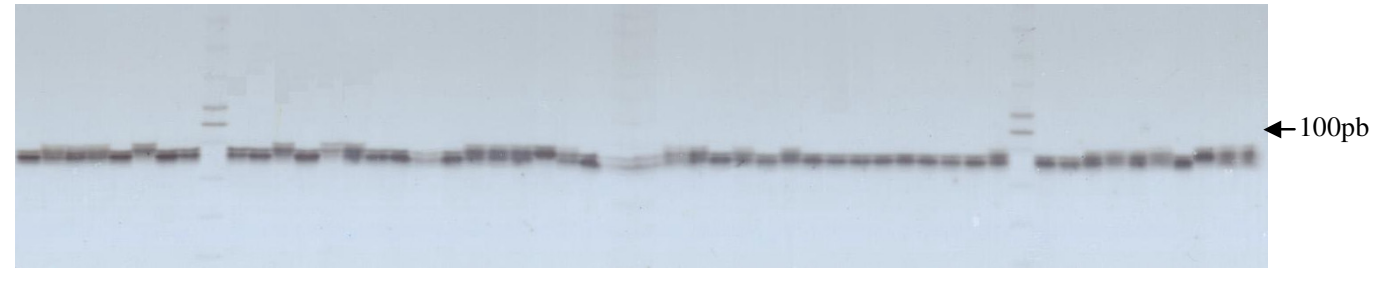

(b)

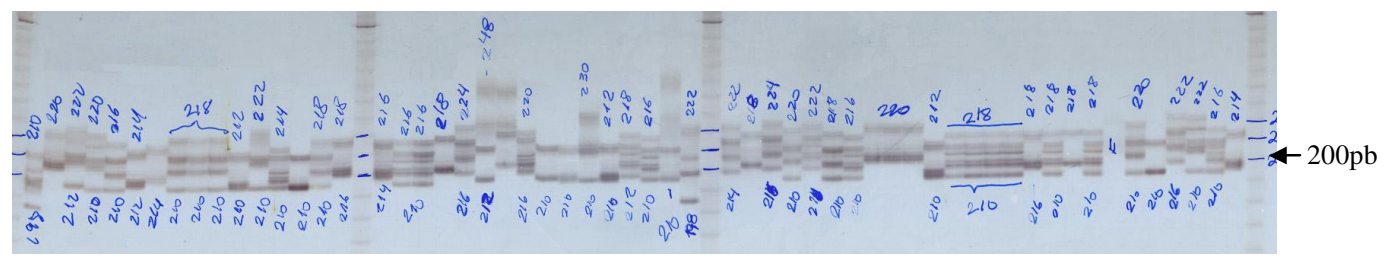

(c)

Figura 3 - Perfis de géis de microssatélites nucleares representando três locos utilizados nas análises. Estão representados (a) população A caracterizada pelo loco CA23, (b) população C caracterizada pelo loco CA144 e (c) população B caracterizada pelo loco CA158

A fim de evitar conclusões precipitadas nesse estudo a respeito do polimorfismo, buscou-se quantificar a magnitude da diversidade gênica. Para tal, comparou-se a diversidade gênica estimada $\left(\hat{H}_{e}\right)$ com a máxima diversidade possível em cada loco de acordo com o número de alelos observados $\left(h_{\max }=(\hat{A}-1) / \hat{A}\right)$. Os locos CA23 e CA158 foram os que apresentaram diversidade gênica mais elevada, uma vez que os dados explicam $98,8 \%$ e $89,7 \%$ da diversidade total possível (Tabela 3). O loco CA144 apresentou estimativas de diversidade intermediárias e para os locos CA53 e CA161, as proporções de diversidade gênica foram inferiores a $10 \%$. 
A baixa diversidade gênica foi decorrente da heterogeneidade das freqüências alélicas nesses locos, ou seja, devido à ocorrência de um alelo com freqüência elevada e poucos alelos raros e também pelo fato dos mesmos serem monomórficos em algumas populações.

Tabela 3. Genética descritiva dos locos de SSR nucleares. $n$ : número de indivíduos amostrados; $\hat{A}=$ número alelos; $\hat{H}_{e}=$ diversidade gênica; $h_{\max }=$ diversidade máxima; $\hat{H}_{e} / h_{\text {max }}=$ proporção da diversidade máxima (em \%)

\begin{tabular}{lccccc}
\hline LOCO & $n$ & $\hat{A}$ & $\hat{H}_{e}$ & $h_{\max }$ & $\hat{H}_{e} / h_{\max }$ \\
\hline CA 23 & 294 & 2 & 0,494 & 0,500 & $98,8 \%$ \\
CA 53 & 294 & 3 & 0,043 & 0,667 & $6,45 \%$ \\
CA 88 & 294 & 1 & 0,000 & - & - \\
CA 144 & 293 & 2 & 0,310 & 0,500 & $62,0 \%$ \\
CA158 & 292 & 17 & 0,847 & 0,940 & $89,7 \%$ \\
CA161 & 293 & 5 & 0,017 & 0,800 & $2,1 \%$ \\
\hline
\end{tabular}

\subsubsection{Marcadores microssatélites cloroplastidiais}

Os seis locos microssatélites cloroplastidiais desenvolvidos por Weising \& Gardner (1999) para angiospermas dicotiledôneas amplificaram em S. Iycocarpum e foram polimórficos. O número de alelos em cada loco foi variável, sendo que foram observados de dois a oito alelos em cada loco (Tabela 4). Em contraposição à baixa diversidade obtida por marcadores microssatélites nucleares, a diversidade genética para os marcadores cloroplastidiais foi elevada (Figura 4). A combinação dos alelos observados nos seis locos cloroplastidiais resultou na deteç̧ão de 89 haplótipos. 


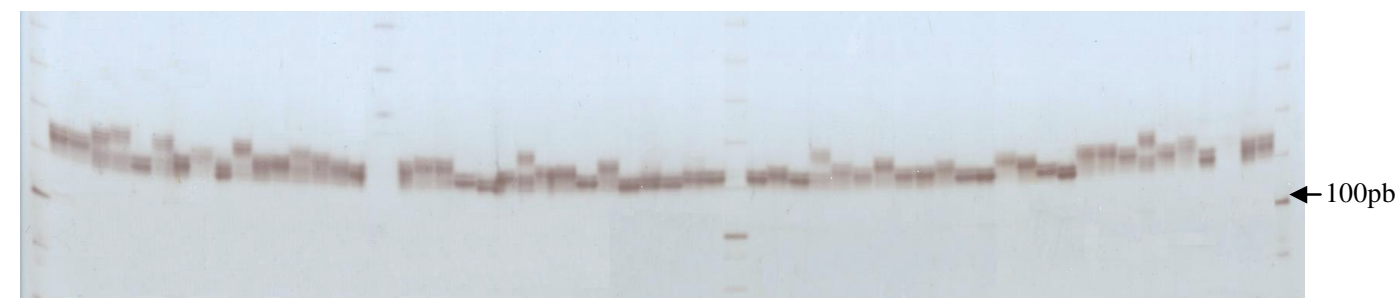

(a)

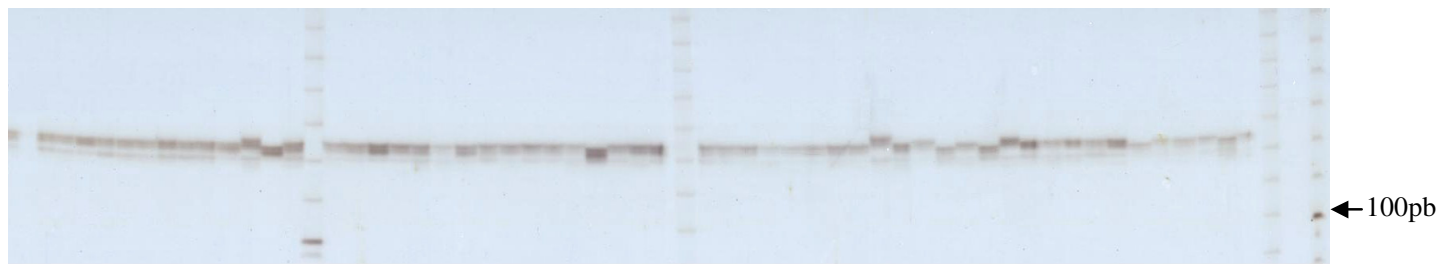

(b)

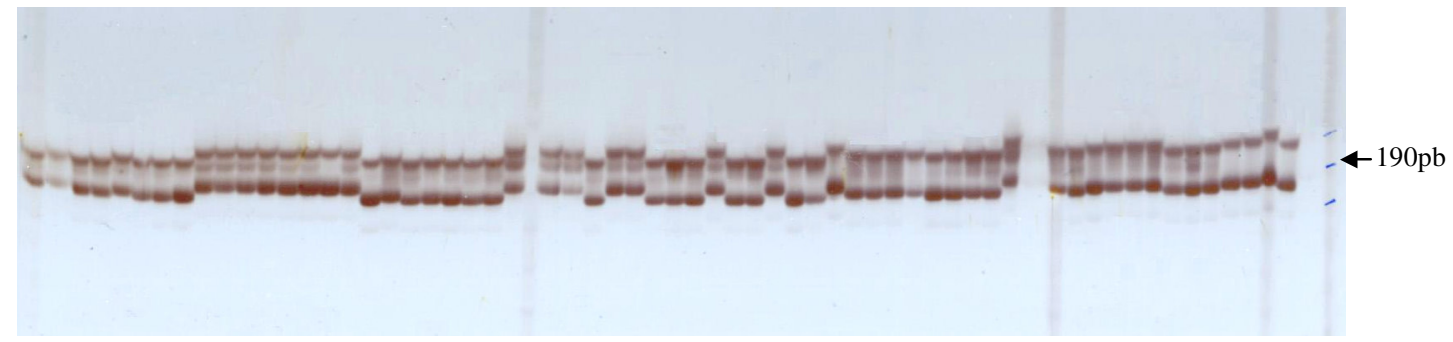

(c)

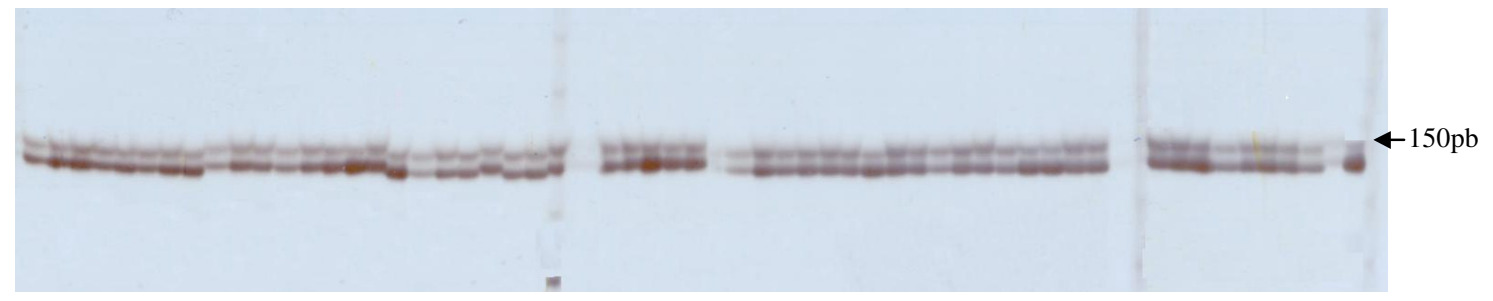

(d)

Figura 4 - Perfis de géis de microssatélites cloroplastidiais representando três locos utilizados nas análises. Estão representados (a) população A caracterizada pelo loco ccmp03, (b) indivíduos da margem da estrada caracterizados pelo loco ccmp05, (c) população D caracterizada pelo loco ccmp02 e (d) população $\mathrm{D}$ caracterizada pelo loco ccmp07 
Tabela 4. Locos de microssatélites cloroplastidiais com as respectivas temperaturas de hibridação $\left(T_{m}\right)$, seqüência dos iniciadores, motivo, número de alelos e amplitudes alélicas em pares de base

\begin{tabular}{|c|c|c|c|c|c|}
\hline Locos & $\begin{array}{l}\mathrm{T}_{\mathrm{m}} \\
\left({ }^{\circ} \mathrm{C}\right)\end{array}$ & $\begin{array}{l}\text { Seqüência dos iniciadores } \\
\qquad\left(5^{\prime}-3^{\prime}\right)\end{array}$ & Motivo* & Alelos & $\begin{array}{l}\text { Amplitude } \\
\text { alélica (pb) }\end{array}$ \\
\hline \multirow[t]{2}{*}{ ccmp02 } & 58 & GATCCCggACgTAATCCTg & $(A)_{11}$ & 5 & 184-192 \\
\hline & & ATCgTACCgAgggTTCgAAT & & & \\
\hline \multirow[t]{2}{*}{ ccmp03 } & 54 & CAgACCAAAAgCTgACATAg & $(\mathrm{T})_{11}$ & 8 & $108-122$ \\
\hline & & gTाTCATTCggСТССТTAT & & & \\
\hline \multirow[t]{2}{*}{ ccmp05 } & 54 & TgTTССААТАТСТTСТTgТСАТT & $(\mathrm{C})_{7}(\mathrm{~T})_{10}$ & 4 & $122-128$ \\
\hline & & AggTTCCATCggAACAATTAT & $(\mathrm{T})_{5} \mathrm{C}(\mathrm{A})_{11}$ & & \\
\hline \multirow[t]{2}{*}{ ccmp07 } & 56 & CAACATATACCACTgTCAAg & $(A)_{13}$ & 3 & $148-152$ \\
\hline & & АСАТСАТТАТТТТАТАСТСТTТС & & & \\
\hline \multirow[t]{2}{*}{ ccmp09 } & 50 & GgATTTgTACATATAggACA & $(\mathrm{T})_{11}$ & 2 & $102-104$ \\
\hline & & СТСААСТСТAAgAAATACTTg & & & \\
\hline \multirow[t]{2}{*}{ ccmp10 } & 56 & TाताताTAgTgAACgTgTCA & $(\mathrm{T})_{14}$ & 3 & $108-112$ \\
\hline & & TTCgTCgDCgTAgTAAATAg & & & \\
\hline
\end{tabular}

* Motivo observado por Weising \& Gardner (1999) em Nicotiana tabacum

\subsection{Teste do Equilíbrio de Hardy-Weinberg}

As probabilidades do teste exato de Fisher mostraram que dos seis locos microssatélites nucleares utilizados nesse estudo, apenas o loco CA158 apresentou desvios significativos das proporções esperadas de Hardy-Weinberg em todas as populações (Tabela 5), ou seja, as freqüências genotípicas observadas não correspondem ao produto das freqüências alélicas.

Os locos CA53 e CA144 mostraram desvios apenas na população A. As pressuposições do Equilíbrio de Hardy-Weinberg (EHW), como ausência de mutação, seleção e migração e ocorrência de cruzamentos ao acaso em populações infinitas, são mais simples do que ocorre em populações naturais. Essa constatação leva-nos a supor que a ocorrência de alguns locos apresentando desvios do EHW é esperada. Ainda 
assim, o teste do EHW é válido por servir como base de comparação com modelos populacionais mais realistas (Weir, 1996).

Tabela 5. Probabilidades exatas (Teste Exato de Fisher) dos desvios das proporções de Hardy-Weinberg em locos microssatélites nucleares nas populações de $S$. lycocarpum

\begin{tabular}{lllllll}
\hline & CA 23 & CA53 & CA 144 & CA 158 & CA 161 & CA 88 \\
\hline Pop A & 0,78594 & $0,00000^{* *}$ & $0,00094 * *$ & $0,003125^{* *}$ & 1,00000 & 1,00000 \\
Pop B & 0,61125 & 1,00000 & 1,00000 & $0,014375 *$ & 1,00000 & 1,00000 \\
Pop C & 0,60594 & 1,00000 & 0,51094 & $0,001563^{* *}$ & 1,00000 & 1,00000 \\
Pop D & 0,58813 & 1,00000 & 0,66219 & $0,000000 * *$ & 1,00000 & 1,00000 \\
Margem & 1,00000 & 1,00000 & 1,00000 & $0,006562 * *$ & 1,00000 & 1,00000 \\
\hline
\end{tabular}

$* p<0,05 ; * * p<0,01$

\subsection{Desequilíbrio genotípico entre pares de locos}

A associação entre genes de locos diferentes foi avaliada por meio do teste do desequilíbrio genotípico entre pares de locos, utilizando-se as freqüências genotípicas obtidas das populações adultas (indivíduos diplóides). Observou-se associação significativa a 95\% entre os locos CA23 e CA158 na população D e na margem da estrada e entre os locos CA23 e CA144 na população D. Como discutido em Weir (1996), em geral as associações entre genes de locos diferentes em indivíduos diplóides (desequilíbrio genotípico) são muito pequenas. Observando-se o conjunto total de populações (Tabela 6), apenas a associação entre os locos CA23 e CA158 foi significativa. 
Tabela 6. Probabilidades do desequilíbrio genotípico entre pares de locos microssatélites nucleares baseadas em 750.000 permutações. O loco CA88 não foi considerado porque é monomórfico em todas as populações

\begin{tabular}{lcccccc}
\hline & Pop A & Pop B & Pop C & Pop D & Margem & TOTAL \\
\hline CA23/CA53 & 0,30885 & 0,86085 & NA & NA & NA & 0,58881 \\
CA23/CA144 & 0,83835 & 0,35657 & 0,80871 & $0,02078^{*}$ & 0,83855 & 0,66132 \\
CA23/CA158 & 0,42524 & 0,41331 & 0,72565 & $0,00104^{*}$ & $0,04884^{*}$ & $0,02946 *$ \\
CA23/CA161 & 0,24472 & 1,00000 & 0,44967 & NA & NA & 0,49878 \\
CA53/CA144 & 0,18674 & 1,00000 & NA & NA & NA & 0,39767 \\
CA53/CA158 & 0,87441 & 0,18885 & NA & NA & NA & 0,45468 \\
CA53/CA161 & 1,00000 & 0,22087 & NA & NA & NA & 0,30026 \\
CA144/CA158 & 0,14893 & 0,26921 & 0,29389 & 0,16845 & 0,48139 & 0,08362 \\
CA144/CA161 & 1,00000 & 0,51353 & 1,0000 & NA & NA & 0,63556 \\
CA158/CA161 & 0,31751 & 0,35608 & 0,18306 & NA & NA & 0,10307 \\
\hline
\end{tabular}

$* p<0,05$; NA não avaliado, pois um dos locos é monomórfico na população

Como o genoma do cloroplasto é haplóide e herdado sem recombinação, espera-se encontrar exatamente o oposto do observado nos locos nucleares, ou seja, a associação entre pares de locos é esperada. As probabilidades obtidas para o conjunto de populações (Tabela 7) mostram associação significativa a $99 \%$ entre alelos de diferentes locos para praticamente todas as combinações. Apenas as combinações com o loco ccmp09 apresentaram probabilidades não significativas. O referido loco apresentou polimorfismo apenas na população $D$, sendo que as probabilidades totais referem-se apenas o observado nessa população. 
Tabela 7. Probabilidades do desequilíbrio genotípico entre pares de locos microssatélites cloroplastidiais baseadas em 750.000 permutações

\begin{tabular}{lllllll}
\hline & Pop A & Pop B & Pop C & Pop D & margem & TOTAL \\
\hline cp02/cp03 & $0,00334^{* *}$ & $0,00002^{* *}$ & $0,00004^{* *}$ & $0,00005^{* *}$ & $0,01373^{*}$ & $0,00000^{* *}$ \\
cp02/cp05 & $0,01786^{*}$ & $0,00231^{* *}$ & 0,24532 & $0,01347^{*}$ & $0,00005^{* *}$ & $0,00000^{* *}$ \\
cp02/cp07 & 0,67676 & 0,41343 & $0,01638^{*}$ & $0,00338^{* *}$ & $0,00855^{* *}$ & $0,00087^{* *}$ \\
cp02/cp09 & NA & NA & NA & 0,17970 & NA & 0,17970 \\
cp02/cp10 & 0,41903 & 0,33795 & 0,66554 & $0,00003^{* *}$ & 0,74486 & $0,00029^{* *}$ \\
cp03/cp05 & $0,00317^{* *}$ & 0,17006 & 0,10897 & $0,00626^{* *}$ & $0,00777^{* *}$ & $0,00001^{* *}$ \\
cp03/cp07 & 0,21558 & 0,27830 & $0,02341^{*}$ & $0,00012^{* *}$ & $0,00983^{* *}$ & $0,00003^{* *}$ \\
cp03/cp09 & NA & NA & NA & 0,22545 & NA & 0,22545 \\
cp03/cp10 & 0,54330 & 0,09397 & 0,71123 & $0,00002^{* *}$ & 0,83627 & $0,00130^{* *}$ \\
cp05/cp07 & 0,09608 & $0,01996 *$ & $0,00293^{* *}$ & $0,00326^{* *}$ & $0,00015^{* *}$ & $0,00000^{* *}$ \\
cp05/cp09 & NA & NA & NA & 0,61339 & NA & 0,61339 \\
cp05/cp10 & 0,11369 & 0,05207 & 0,18904 & $0,00012^{* *}$ & 1,0000 & $0,00005^{* *}$ \\
cp07/cp09 & NA & NA & NA & 0,66067 & NA & 0,66067 \\
cp07/cp10 & 0,35631 & 0,73970 & 0,05659 & $0,00423^{*}$ & 0,56055 & $0,00846 * *$ \\
cp09/cp10 & NA & NA & NA & 0,24256 & NA & 0,24256 \\
\hline
\end{tabular}

${ }^{*} p<0,05 ;{ }^{* *} p<0,01$; NA não avaliado, pois um dos locos é monomórfico na população

Observa-se, especialmente para os locos cloroplastidiais, que a proporção de locos associados varia entre as populações. A população $D$ e as plantas da margem da estrada foram as que apresentaram a menor proporção de associações não significativas, $33 \%$ e $40 \%$ respectivamente. Esses resultados indicam que essas populações podem não ter atingido o equilíbrio. Além da ligação entre locos, a ocorrência de desequilíbrio de ligação em populações locais pode ser resultante de diversos fatores, como discutido em Hartl \& Clark (1997). O desequilíbrio na população fundadora e tempo insuficiente para dissipá-lo pode ser uma possível causa, especialmente em genomas não recombinantes como o cloroplastidial, o qual requer um tempo mais longo para atingir o equilíbrio. Outra causa possível é quando a população é resultante de uma mistura de indivíduos de populações com freqüências 
gaméticas diferentes. Outra possibilidade é a seleção natural, uma vez que pode favorecer determinadas combinações alélicas.

\subsection{Herança do genoma cloroplastidial}

Em todas as 242 progênies caracterizadas com os seis locos cloroplastidiais não foi observada heteroplasmia, ou seja, os indivíduos apresentaram apenas um alelo por loco, o que indica que a herança do cloroplasto para esta espécie é uniparental. Com exceção de um indivíduo, o haplótipo observado nas progênies foi semelhante ao haplótipo materno. $O$ indivíduo apresentando haplótipo diferente do materno foi observado na família B12. A diferença de genótipo foi constatada apenas no loco ccmp10 (Figura 5).

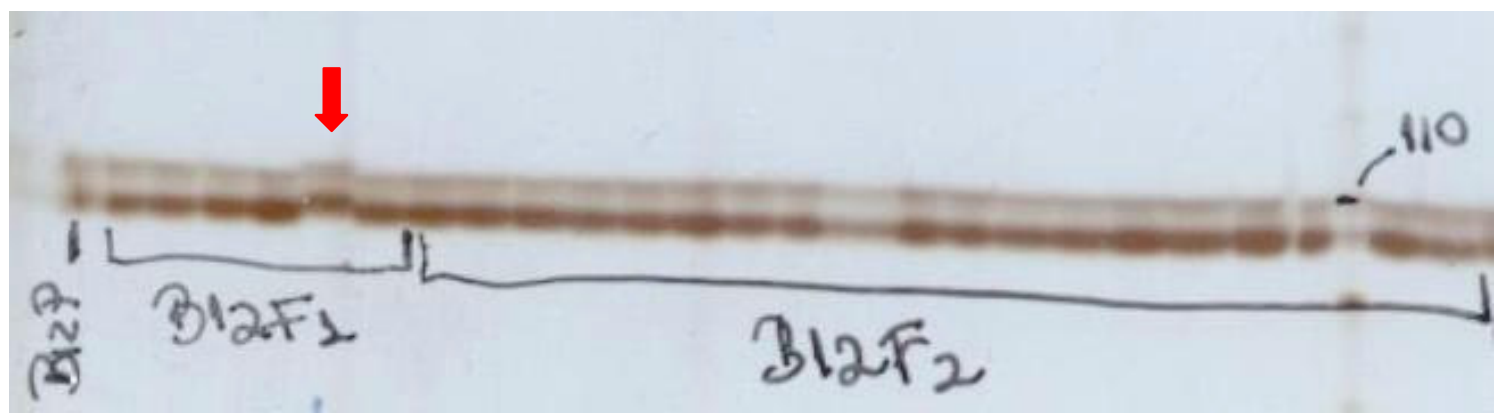

Figura 5 - Família B12 caracterizada pelo loco ccmp10. A primeira canaleta (B12P) indica o genótipo materno e os demais são as progênies oriundas de dois frutos (B12F1 e B12F2). A seta indica o indivíduo com alelo diferente do materno. $O$ número 110 indica o marcador em pares de base

Como apenas um loco apresentou alelo diferente do observado na árvore materna, a primeira possibilidade a ser considerada é a ocorrência de um erro durante as análises laboratoriais. Ressalta-se, entretanto, que todos procedimentos laboratoriais para essa família foram repetidos para confirmação dos resultados.

Há também a possibilidade de ocorrência de mutação. A taxa de mutação em locos microssatélites cloroplastidiais foi estimada entre $3,2 \times 10^{-5}$ e $7,9 \times 10^{-5}$ substituições 
por geração (Provan et al., 1999). Apesar dessas estimativas serem cerca de 100 vezes menores do que o observado por Goldstein \& Pollock (1997) em locos microssatélites nucleares $\left(10^{-3}\right)$, a possibilidade de ocorrência de uma mutação não deve ser descartada, apesar de ser um evento raro.

A terceira explicação é a ocorrência de herança paterna do cloroplasto. Embora se considere que em angiospermas a herança do cloroplasto é estritamente materna, as transmissões paterna e biparental de organelas já foram constatadas em algumas espécies. Corriveau \& Coleman (1988) suspeitam que ocorra herança biparental em cerca de 20 a $50 \%$ das angiospermas.

Considerando essa possibilidade como verdadeira, pode-se constatar que a probabilidade de transmissão paterna para $S$. lycocarpum é muito baixa, uma vez que somente foi detectada em uma amostragem de 242 plantas. Como as progênies são de polinização aberta, procedeu-se ao cálculo do número de progênies informativas (eq.2 do item 3.5.3), ou seja, do total de cruzamentos em que ambos os parentais são esperados por carregar genótipos cloroplastidiais diferentes.

As progênies de duas matrizes da população B e de uma matrizes da população $\mathrm{C}$ foram descartadas porque apresentaram haplótipos que não haviam sido detectados na amostragem dos adultos e, portanto, não tinham as freqüências haplotípicas estimadas. Das 222 progênies utilizadas, cerca de 183 (82,43\%) eram informativas e foram utilizadas para estimação da taxa máxima de transmissão paterna do cloroplasto $(P$ ) com uso da eq. 1 (item 3.5.3). Esta foi obtida para cada população individualmente e para o total de progênies analisadas (Tabela 8).

No cálculo da probabilidade de transmissão paterna $(P)$ na população $\mathrm{B}$, a ocorrência de um indivíduo na progênie com haplótipo diferente do materno não foi considerada. Entretanto, se o haplótipo diferente for considerado como herança paterna, a probabilidade calculada com a eq. 1 é muito próxima de zero. 
Tabela 8. Probabilidade de transmissão paterna do cloroplasto $(P$ ) nas populações $A, B$ e C e no total de progênies. $N=$ número de progênies; $N_{\text {inf }}=$ número de progênies informativas, $\beta=$ poder do teste estatístico

\begin{tabular}{lcccc}
\hline População & $N$ & $N_{\text {inf }}$ & $P(\beta>0,95)$ & $P(\beta>0,99)$ \\
\hline A & 24 & 18 & 0,150 & 0,174 \\
B & 134 & 131 & 0,023 & 0,034 \\
C & 36 & 34 & 0,085 & 0,120 \\
Total & 222 & 183 & 0,016 & 0,023 \\
\hline
\end{tabular}

Os valores de probabilidade de transmissão paterna $(P)$ obtidos pelo uso da metodologia descrita por Milligan (1992) (Tabela 8) não correspondem exatamente à taxa de transmissão paterna de cloroplasto para $S$. lycocarpum. O método está mais relacionado ao tamanho amostral requerido para não aceitar falsamente a hipótese de herança estritamente materna.

Para o total de progênies, por exemplo, os resultados mostram que é necessário amostrar 222 progênies de polinização aberta para reconhecer com 95\% de segurança a transmissão paterna do cloroplasto quando essa é de 1,6\%. Para o pequeno tamanho amostral da população A (24 progênies), por outro lado, não se pode aceitar a hipótese de herança estritamente materna, mesmo com uma taxa de transmissão paterna do cloroplasto da ordem de 15\%. Logo, são requeridos tamanhos amostrais grandes para que o valor potencial do $P$ esteja próximo de zero.

\subsection{Diversidade genética intrapopulacional}

\subsubsection{Marcadores microssatélites nucleares}

Os padrões de freqüências alélicas não diferiram entre as populações, ou seja, em todas as populações o alelo mais freqüente foi o mesmo. Observou-se diferença acentuada apenas nas freqüências gênicas do loco CA23 entre a população D e as demais (Tabela 9). O loco CA 53 apresentou alelos raros nas populações A e B e monomorfismo nas populações C e D e nos indivíduos na margem da estrada. 
Monomorfismo na população $D$ e nos indivíduos na margem da estrada também foi observado no loco CA161.

Tabela 9. Freqüência dos alelos em seis locos microssatélites nucleares nas populações naturais e nos indivíduos amostrados na margem da estrada

\begin{tabular}{|c|c|c|c|c|c|c|}
\hline \multirow[t]{2}{*}{ Loco } & \multirow{2}{*}{$\begin{array}{l}\text { Amostra/ } \\
\text { alelos }\end{array}$} & \multicolumn{4}{|c|}{ Populações naturais } & \multirow{2}{*}{$\begin{array}{c}\text { Margem da } \\
\text { estrada }\end{array}$} \\
\hline & & $A$ & B & $\mathrm{C}$ & $\mathrm{D}$ & \\
\hline \multirow[t]{3}{*}{ CA 23} & $(n)$ & 58 & 60 & 60 & 56 & 60 \\
\hline & 100 & 0,543 & 0,550 & 0,525 & 0,143 & 0,442 \\
\hline & 102 & 0,457 & 0,450 & 0,475 & 0,857 & 0,558 \\
\hline \multirow{4}{*}{ CA53 } & $(n)$ & 58 & 60 & 60 & 56 & 60 \\
\hline & 190 & 0,017 & 0,058 & - & - & - \\
\hline & 192 & 0,948 & 0,942 & 1,000 & 1,000 & 1,000 \\
\hline & 194 & 0,034 & - & - & - & - \\
\hline \multirow[t]{2}{*}{ CA 88} & $(n)$ & 60 & 60 & 60 & 60 & 55 \\
\hline & 140 & 1,000 & 1,000 & 1,000 & 1,000 & 1,000 \\
\hline \multirow{3}{*}{ CA 144} & $(n)$ & 58 & 60 & 60 & 56 & 60 \\
\hline & 86 & 0,836 & 0,842 & 0,742 & 0,800 & 0,825 \\
\hline & 88 & 0,164 & 0,158 & 0,258 & 0,200 & 0,175 \\
\hline \multirow[t]{19}{*}{ CA 158} & $(n)$ & 58 & 60 & 60 & 54 & 60 \\
\hline & 198 & 0,017 & 0,017 & - & 0,019 & - \\
\hline & 204 & - & - & - & - & - \\
\hline & 206 & - & - & - & 0,028 & - \\
\hline & 208 & - & - & 0,025 & 0,065 & 0,025 \\
\hline & 210 & 0,353 & 0,325 & 0,292 & 0,259 & 0,292 \\
\hline & 212 & 0,078 & 0,083 & 0,033 & 0,037 & 0,033 \\
\hline & 214 & 0,069 & 0,050 & 0,117 & 0,259 & 0,117 \\
\hline & 216 & 0,095 & 0,133 & 0,183 & 0,111 & 0,183 \\
\hline & 218 & 0,233 & 0,175 & 0,108 & 0,028 & 0,108 \\
\hline & 220 & 0,052 & 0,108 & 0,100 & 0,019 & 0,100 \\
\hline & 222 & 0,009 & 0,058 & 0,042 & 0,028 & 0,042 \\
\hline & 224 & 0,086 & 0,017 & 0,042 & 0,037 & 0,042 \\
\hline & 226 & 0,009 & - & 0,025 & 0,083 & 0,025 \\
\hline & 228 & - & - & 0,017 & - & 0,017 \\
\hline & 230 & - & 0,008 & - & 0,028 & - \\
\hline & 244 & - & - & 0,008 & - & 0,008 \\
\hline & 246 & - & & 0,008 & - & 0,008 \\
\hline & 248 & - & 0,025 & - & - & - \\
\hline \multirow[t]{6}{*}{ CA161 } & $(n)$ & 58 & 60 & 60 & 55 & 60 \\
\hline & 174 & 0,017 & - & - & - & - \\
\hline & 178 & 0,983 & 0,983 & 0,992 & 1,000 & 1,000 \\
\hline & 180 & - & - & 0,008 & - & - \\
\hline & 182 & - & 0,008 & - & - & - \\
\hline & 186 & - & 0,008 & - & - & - \\
\hline
\end{tabular}


Para as estimativas de diversidade genética, optou-se por excluir o loco CA 88, pelo fato do mesmo ser monomórfico em todas as populações. As estimativas médias foram, portanto, calculadas com os dados de cinco locos.

As estimativas de número médio de alelos por loco $(\hat{A}=3,88 \pm 0,15)$ foram baixas se comparadas ao observado em outros estudos realizados com locos microssatélites. O número efetivo de alelos por loco $\left(\hat{A}_{e}=2,34 \pm 0,09\right)$ foi inferior ao número de alelos devido à distribuição desigual das freqüências gênicas nos locos, já evidenciada anteriormente (Tabela 10). A diversidade gênica $\left(\hat{H}_{e}=0,330 \pm 0,013\right)$ e heterozigosidade observada $\left(\hat{H}_{o}=0,302 \pm 0,014\right)$ foram reduzidas em comparação ao que se espera para marcadores microssatélites, mas foram coerentes com o número de alelos. A variação entre locos em todas as estimativas de genética descritiva pode ser visualizada por meio dos amplos erros-padrão observados em cada população. $\mathrm{Na}$ população $D$ as estimativas de diversidade genética foram ligeiramente inferiores ao observado nas demais populações, porém, como os erros-padrão se sobrepõem, a diferença não foi significativa.

Nas populações B, C e D, estimativas de heterozigosidade observada $\left(\hat{H}_{o}\right)$ foram praticamente similares à diversidade gênica $\left(\hat{H}_{e}\right)$, como pode ser observado pelas estimativas de índices de fixação (Tabela 10). Embora os intervalos de confiança do $\hat{f}$ foram amplos, devido à variação entre locos, o índice de fixação não diferiu estatisticamente de zero nestas populações. Os indivíduos situados na margem da estrada apresentaram índice de fixação estatisticamente diferente de zero, porém a magnitude do desvio foi pequena ( $\hat{f}=0,083$ ). Na população $\mathrm{A}$, três locos apresentaram desvios significativos do EHW e, como conseqüência, o $\hat{f}$ diferiu de zero e indica que o desvio foi causado por excesso de genótipos homozigóticos $(\hat{f}=0,214)$.

As estimativas dos índices de diversidade genética mostraram que não há diferença significativa entre as populações naturais e as plantas na margem da estrada, 
dando indícios que a colonização de ambientes alterados por S. lycocarpum é eficiente e não está resultando em prejuízos genéticos para espécie.

Tabela 10. Estimativas de índices de diversidade genética para microssatélites nucleares. ( $n=$ tamanho amostral; $\hat{A}=$ número médio de alelos por loco; $\hat{A}_{e}=$ número efetivo de alelos por loco; $\hat{H}_{e}=$ diversidade gênica; $\hat{H}_{o}=$ heterozigosidade observada; $\hat{f}$ =índice de fixação)

\begin{tabular}{ccccccc}
\hline População & $n$ & $\hat{A}$ & $\hat{A}_{e}$ & $\hat{H}_{e}$ & $\hat{H} \hat{f}_{o}$ & $\hat{f}\left(\mathrm{IC}_{99 \%}\right)^{*}$ \\
\hline A & 58 & 3,80 & 2,09 & 0,342 & 0,269 & 0,214 \\
& & $(1,56)$ & $(0,73)$ & $(0,139)$ & $(0,138)$ & $(0,0002$ a 0,814$)$ \\
\multirow{2}{*}{ B } & 60 & 4,20 & 2,35 & 0,348 & 0,350 & $-0,006$ \\
& & $(1,71)$ & $(0,87)$ & $(0,144)$ & $(0,138)$ & $(-0,067$ a 0,052$)$ \\
C & \multirow{2}{*}{60} & 4,20 & 2,62 & 0,353 & 0,313 & 0,077 \\
& & $(2,45)$ & $(1,18)$ & $(0,161)$ & $(0,138)$ & $(-0,094$ a 0,170$)$ \\
D & 55,33 & 3,40 & 2,24 & 0,283 & 0,278 & 0,0016 \\
& & $(1,92)$ & $(1,04)$ & $(0,154)$ & $(0137)$ & $(-0,158$ a 0,123$)$ \\
Margem & \multirow{2}{*}{60} & 3,80 & 2,39 & 0,327 & 0,300 & 0,083 \\
& & $(2,31)$ & $(1,05)$ & $(0,160)$ & $(0,142)$ & $(0,027$ a 0,135$)$ \\
Média & & 3,88 & 2,34 & 0,330 & 0,302 & 0,071 \\
& & $(0,15)$ & $(0,09)$ & $(0,013)$ & $(0,014)$ & $(-0,046$ a 0,313$)$
\end{tabular}

( ) erros-padrão; *(IC) intervalo de confiança a $99 \%$ de probabilidade, usando 10.000 reamostragens "bootstrap" sobre locos

\subsubsection{Marcadores cloroplastidiais}

O número médio de haplótipos por população $\left(\hat{n}_{h}=28,4 \pm 2,67\right)$ e a diversidade haplotípica ( $\hat{h}=0,947 \pm 0,012$ ) foram elevados (Tabela 11), mostrando que tanto as populações naturais como a margem da estrada foram fundadas por um número elevado de linhagens maternas, ou seja, foram colonizadas por sementes originadas em 
diferentes populações. Como já detectado para os marcadores nucleares, a população $\mathrm{D}$ foi a que apresentou o menor número de haplótipos $\left(\hat{n}_{h}=19\right)$ e a menor diversidade haplotípica $(\hat{h}=0,910)$ quando comparada às demais populações, indicando que a população foi fundada por um número proporcionalmente menor de linhagens maternas.

Tabela 11. Estimativa de parâmetros de diversidade genética para haplótipos cloroplastidiais. $\hat{n}_{h}=$ número de haplótipos; $\hat{n}_{e}=$ número efetivo de haplótipos por loco; $\hat{n}_{p}=$ número de haplótipos privados; $\hat{n}_{p} / \hat{n}_{h}=$ proporção de haplótipos privados, $\hat{h}=$ diversidade haplotípica

\begin{tabular}{cccccc}
\hline População & $\hat{n}_{h}$ & $\hat{n}_{e}$ & $\hat{n}_{p}$ & $\hat{n}_{p} / \hat{n}_{h}$ & $\hat{h}$ \\
\hline A & 35 & 17,75 & 13 & $37,1 \%$ & 0,972 \\
B & 31 & 15,72 & 11 & $35,5 \%$ & 0,973 \\
C & 27 & 13,99 & 11 & $40,7 \%$ & 0,932 \\
D & 19 & 9,94 & 13 & $68,4 \%$ & 0,910 \\
Margem & 30 & 15,39 & 07 & $23,3 \%$ & 0,950 \\
Média & 28,4 & 14,56 & & & 0,947 \\
(erro-padrão) & $(2,67)$ & $(1,30)$ & - & - & $(0,012)$ \\
\hline
\end{tabular}

O número de haplótipos privados foi mais elevado nas populações naturais do que nos indivíduos situados na margem da estrada. Apenas 23,3\% dos haplótipos detectados na margem da estrada são exclusivos. Como esperado, quase $70 \%$ dos haplótipos da população mais distante geograficamente das demais (D) são privados. Em todas as populações, o número efetivo de haplótipos $\left(\hat{n}_{e}\right)$ foi praticamente metade do número total de haplótipos (Tabela 11). A heterogeneidade das freqüências dos haplótipos foi que contribuiu para a baixa estimativa do $\hat{n}_{e}$. 
Cerca de $55 \%$ dos haplótipos foram amostrados apenas uma vez e $25 \%$ ocorreram duas vezes (Figura 6), dando indícios de que haplótipos podem não ter sido amostrados nesse estudo. Na população B, por exemplo, em que um número maior de indivíduos deixou de ser amostrado, a estimativa de diversidade haplotípica pode estar subestimada.

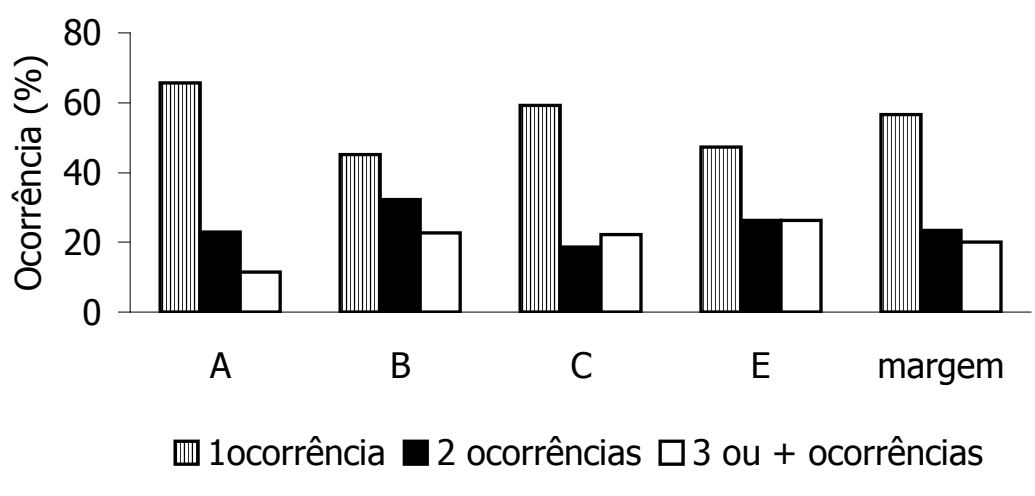

Figura 6 - Distribuição dos haplótipos de acordo com a ocorrência nas populações

Pela distribuição dos haplótipos observa-se que propágulos vindos das populações naturais amostradas contribuíram para a colonização das regiões antrópicas adjacentes, como as margens das estradas. Em todas as populações, há muitos haplótipos que ocorreram apenas uma vez e, portanto, apresentam baixa freqüência, e apenas alguns com freqüência um pouco maior (Figura 7). 

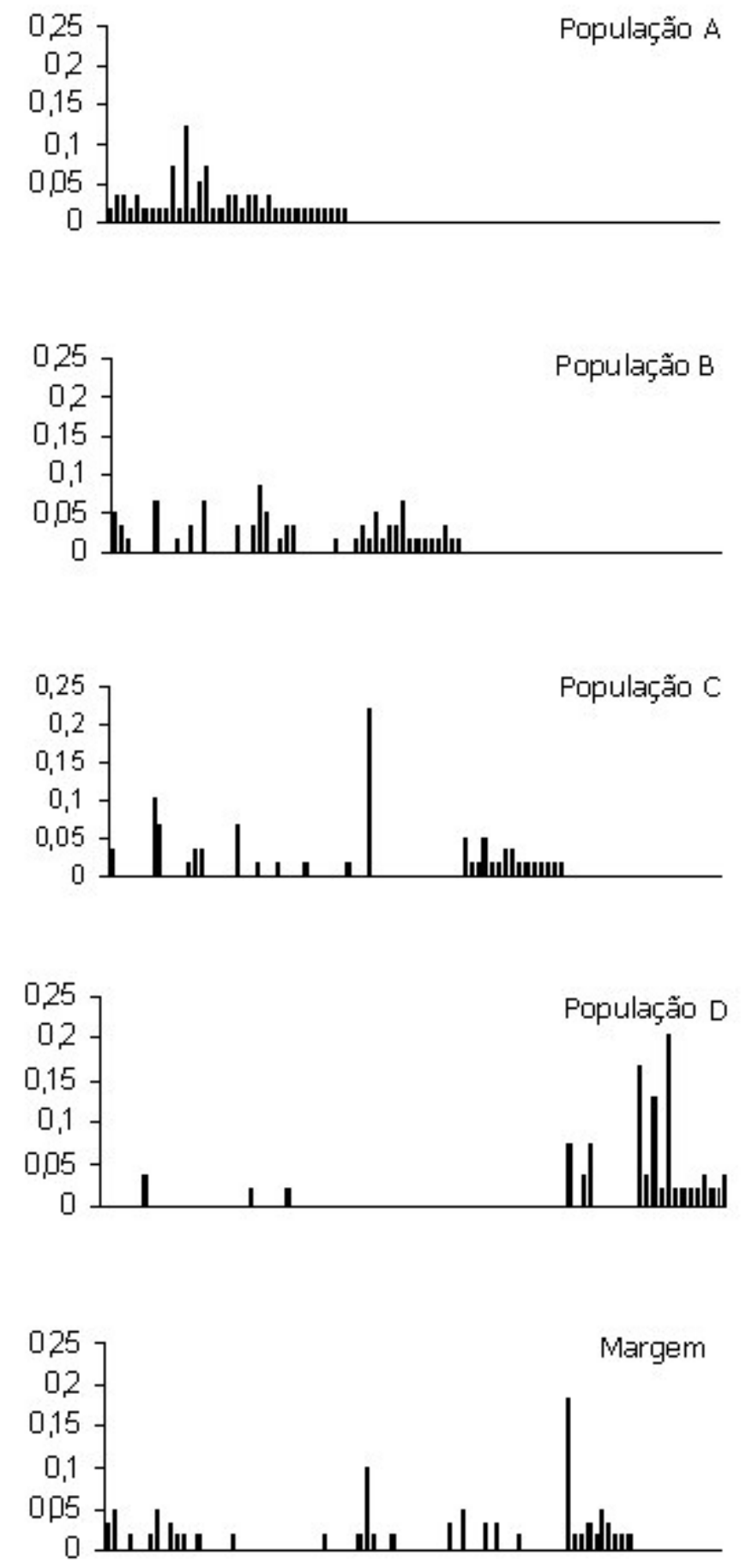

haplótipos de cpDNA

Figura 7 - Freqüência de ocorrência dos haplótipos de DNA cloroplastidial nas quatro populações e nos indivíduos amostrados na margem da estrada 


\subsection{Correlação espacial dos genótipos}

Para análise de autocorrelação espacial dos genótipos, foram obtidos correlogramas para as quatro populações naturais. Comparando-se os correlogramas obtidos para cada população com marcadores nucleares (Figura 8) e cloroplastidiais (Figura 9), observa-se que apenas nas populações B e D a autocorrelação espacial foi significativa a $95 \%$ a uma distância de cerca de $50 \mathrm{~m}$. Na população $\mathrm{D}$, a correlação apresentou maior magnitude na primeira classe de distância ( $\hat{r}=0,248$ e 0,251 com marcadores nucleares e cloroplastidiais, respectivamente). Na população $B$, embora os valores tenham sido menores $(\hat{r}=0,056$ e 0,059 com marcadores nucleares e cloroplastidiais, respectivamente), a correlação obtida para marcadores cloroplastidiais foi significativa nas duas primeiras classes de distância. Os valores de correlação na população B podem estar subestimados, uma vez que, durante as coletas, evitou-se amostrar indivíduos que estavam espacialmente muito próximos.

$\mathrm{Na}$ população C, embora o padrão do correlograma obtido com os microssatélites nucleares tenha mostrado que nas duas primeiras classes de distância a correlação genética é positiva, a estimativas não foram significativas (Figura 8).

A significância do correlograma como um todo foi avaliada apenas para as populações $B$ e $D$, pois essas apresentaram correlação altamente significativa em pelo menos uma classe de distância. Ambos os correlogramas obtidos para as populações $B$ e $D$ foram significativos como um todo, pois pelo menos uma das correlações significativas a 0,05 também foram a um nível $\alpha / 11=0,0045$. A significância do correlograma como um todo indica que o padrão observado de autocorrelação espacial, dos indivíduos separados por uma distância média de até cerca de $50 \mathrm{~m}$ serem geneticamente mais semelhantes que os situados em distâncias maiores, é uma representação real do padrão que ocorre nas populações.

Acredita-se que principalmente a dispersão de sementes espacialmente restrita, e também a propagação vegetativa contribuíram para a autocorrelação espacial nas populações B e D. A contribuição de cada uma pode ser visualizada por meio da análise de coancestralidade, apresentada no próximo item. Como na população D o valor da correlação na primeira classe de distância foi muito elevado, acredita-se que a 
ocorrência de propagação vegetativa nessa população tenha sido mais acentuada que na população $B$.
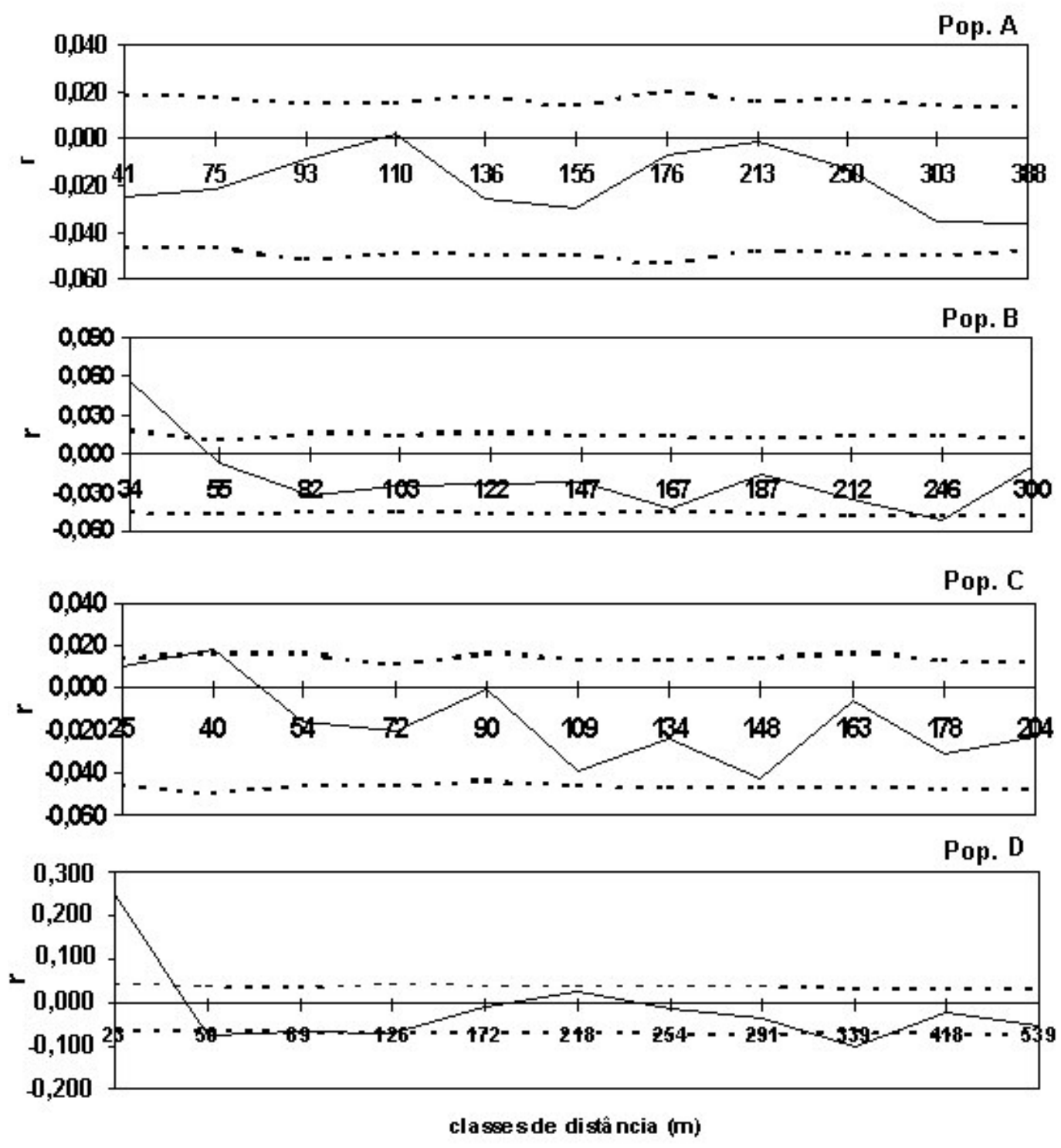

Figura 8 - Autocorrelação espacial multialélica por microssatélites nucleares, calculada para os indivíduos de $S$. Iycocarpum nas populações A, B, C e D. Foram obtidas onze classes de distâncias. A linha contínua indica a correlação (r) e as linhas pontilhadas são os limites inferior e superior do intervalo de confiança a $95 \%$ obtido por 1000 permutações 
Pop. A

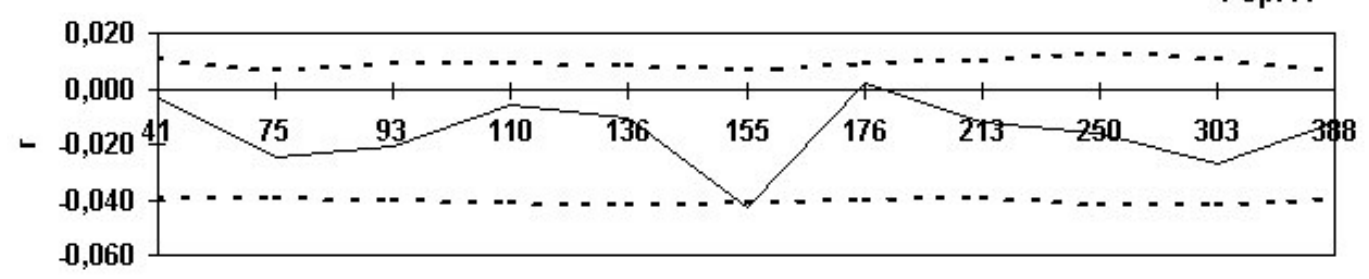

Pop. B

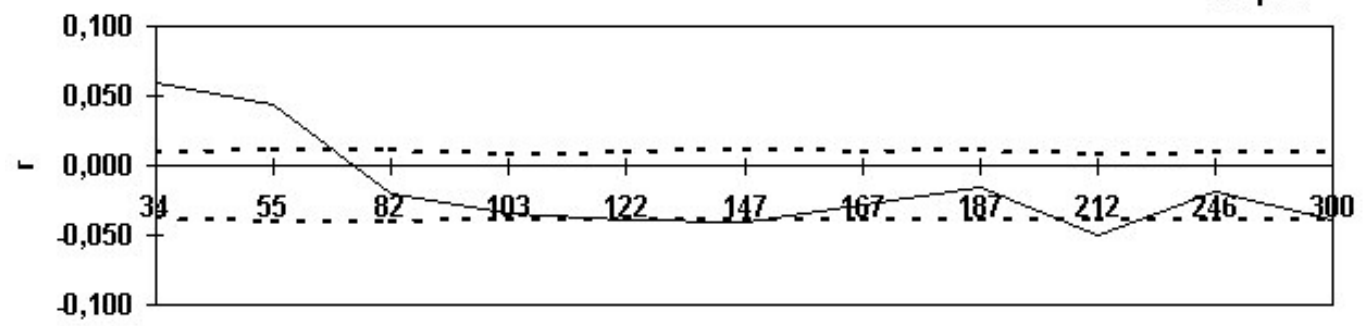

Pop. C

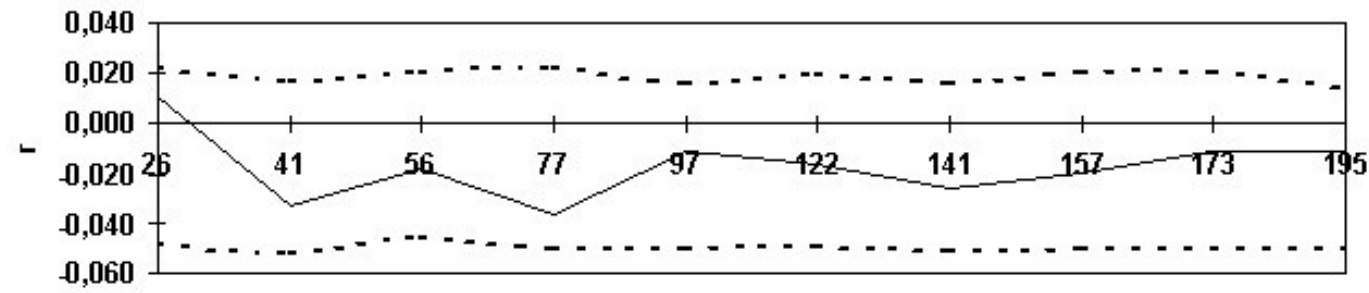

Pop. D

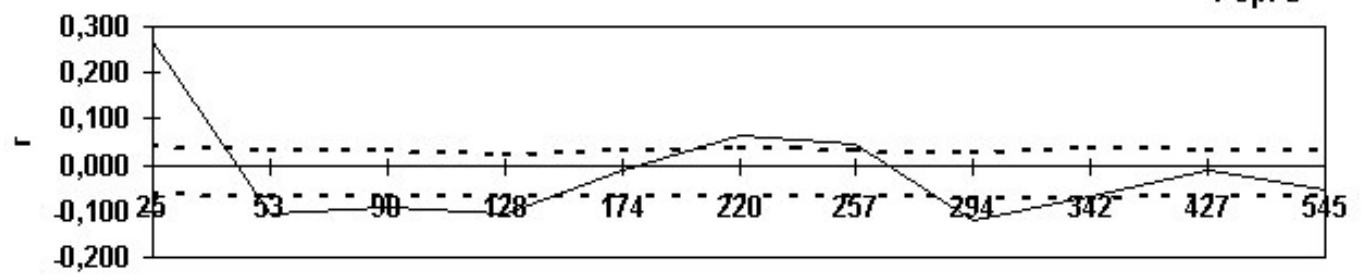

Classes de distância (m)

Figura 9 - Autocorrelação espacial multialélica por marcadores cloroplastidiais para os indivíduos de $S$. lycocarpum nas populações A, B, C e D. Foram obtidas onze classes de distâncias. A linha contínua indica a correlação ( $r$ ) e as linhas pontilhadas são os limites inferior e superior do intervalo de confiança de 95\% obtido por 1000 permutações 


\subsection{Coeficiente de coancestralidade}

As estimativas médias de coancestralidade obtidas a partir da comparação de todos os pares de indivíduos foram praticamente nulas nas populações $A, B$ e $C$ e nas plantas da margem da estrada (Figura 10). Apesar das estimativas terem sido obtidas com o uso de poucos locos (seis) e reduzido número de alelos (30), constata-se, pela pequena amplitude dos erros-padrão, que as mesmas são consistentes. Na população $D$, embora a estimativa média tenha sido baixa $\left(\hat{\theta}_{x y(p o p)}=0,0674\right)$, foi quase quatro vezes maior que nas outras populações e com coancestralidade semelhante ao esperado para primos de primeiro grau $\left(\hat{\theta}_{x y}=0,0625\right)$.

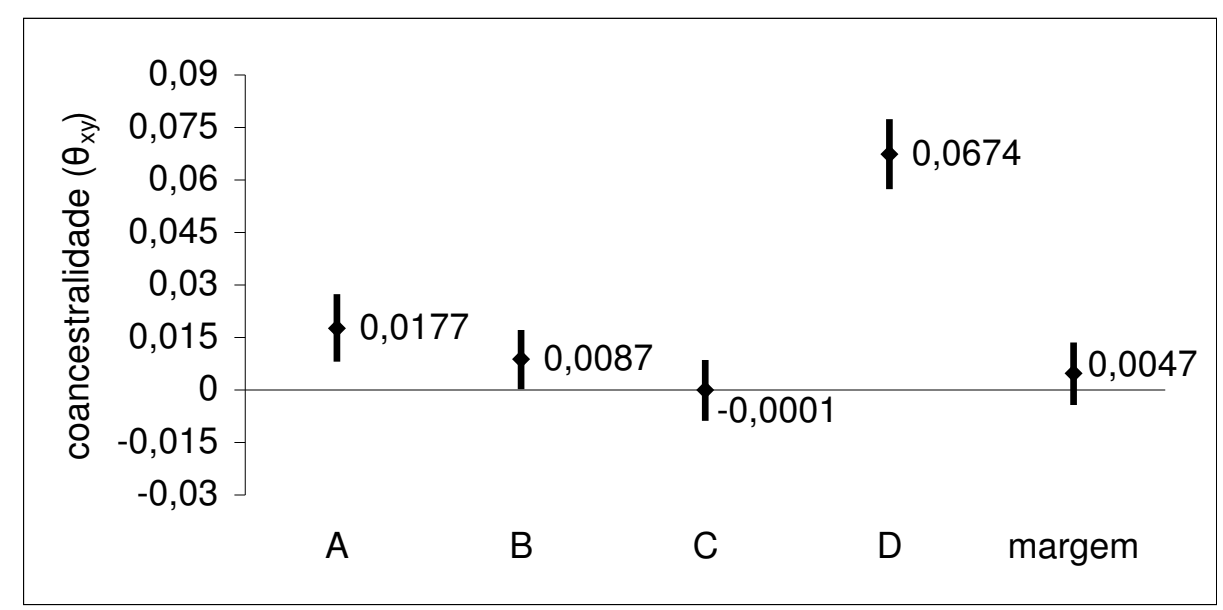

Figura 10 - Coancestralidade média nas quatro populações naturais e nos indivíduos amostrados na margem da estrada. Intervalo de confiança obtido por $1,96 x$ erro padrão

A confiabilidade das estimativas nas populações adultas pôde ser comprovada pela estimação da coancestralidade entre indivíduos com pedigree conhecido. A coancestralidade média dentro de progênies de polinização aberta $\left(\hat{\theta}_{x y}=\right.$ 
0,1371 $\pm 0,0125)$ foi próxima à esperada para meios-irmãos em populações panmíticas $(0,125)$. Pela comparação entre as estimativas de coancestralidade obtidas nas progênies de cada população, observa-se que o tamanho amostral contribuiu para a consistência da estimativa (Tabela 12). Na população em que a amostragem de progênies foi maior (B), a coancestralidade média foi a mais próxima da esperada para meios-irmãos e o erro-padrão foi também o que apresentou menor amplitude.

Tabela 12. Coancestralidade nas progênies de polinização aberta das populações $A$, B e C e erros-padrão

\begin{tabular}{ccccc}
\hline População & Matrizes & Plantas & $\hat{\theta}_{x y}$ & Erro padrão \\
\hline A & 02 & 24 & 0,1410 & 0,0296 \\
B & 09 & 154 & 0,1256 & 0,0044 \\
C & 03 & 54 & 0,1684 & 0,0075 \\
Média ponderada & 14 & 232 & 0,1371 & 0,0125 \\
\hline
\end{tabular}

A porcentagem de pares de indivíduos que compartilhavam genótipos nucleares e cloroplastidiais idênticos (grupo ID) foi praticamente nula na maioria das populações, sendo a maior proporção observada na população D (1,23\%) (Tabela 13). Como o número de locos analisados foi reduzido, não é possível afirmar com segurança que os indivíduos considerados idênticos nesse estudo são irmãos clonais, tanto que foram detectados indivíduos geneticamente idênticos para esses locos que estavam distantes muitos metros uns dos outros. A estimativa do coancestralidade média nesse grupo foi semelhante ao esperado para irmãos clonais e para irmãos de autofecundação $(0,50)$. 
Tabela 13. Coancestralidade média nas populações $\left(\hat{\theta}_{x y(p o p)}\right)$ e nos grupos formados por pares de indivíduos com genótipos nucleares e cloroplastidiais idênticos (ID), com genótipos cloroplastidiais idênticos e genótipos nucleares distintos (LM) e genótipos nucleares e cloroplastidiais distintos (NP); (\%) número relativo de pares de indivíduos em cada grupo

\begin{tabular}{|c|c|c|c|c|c|c|c|c|}
\hline \multirow[b]{2}{*}{ População } & \multirow[b]{2}{*}{$\mathrm{N}$} & \multicolumn{2}{|c|}{ ID } & \multicolumn{2}{|c|}{ LM } & \multicolumn{2}{|c|}{ NP } & \multirow{2}{*}{$\begin{array}{l}\text { Total } \\
\hat{\theta}_{x y}(p o p)\end{array}$} \\
\hline & & $\%$ & $\hat{\theta}_{x y}$ & $\%$ & $\hat{\theta}_{x y}$ & $\%$ & $\hat{\theta}_{x y}$ & \\
\hline \multirow[t]{2}{*}{$A$} & 58 & 0,19 & 0,5000 & 2,48 & $-0,0273$ & 97,33 & 0,0176 & 0,0177 \\
\hline & & & $(0,000)$ & & $(0,0191)$ & & $(0,0044)$ & $(0,0044)$ \\
\hline \multirow[t]{2}{*}{$B$} & 60 & 0,28 & 0,5000 & 2,37 & 0,0338 & 97,35 & 0,0069 & 0,0087 \\
\hline & & & $(0,000)$ & & $(0,0270)$ & & $(0,0038)$ & $(0,0038)$ \\
\hline \multirow[t]{2}{*}{ C } & 60 & 0,17 & 0,5000 & 6,38 & $-0,0350$ & 93,45 & 0,0013 & $-0,0001$ \\
\hline & & & $(0,000)$ & & $(0,0130)$ & & $(0,0039)$ & $(0,0038)$ \\
\hline \multirow[t]{2}{*}{ D } & 57 & 1,23 & 0,5000 & 6,69 & 0,1796 & 92,08 & 0,0537 & 0,0674 \\
\hline & & & $(0,000)$ & & $(0,0219)$ & & $(0,0046)$ & $(0,0048)$ \\
\hline \multirow[t]{2}{*}{ Margem } & 59 & 0,17 & 0,5000 & 4,97 & $-0,0090$ & 94,86 & 0,0045 & 0,0047 \\
\hline & & & $(0,000)$ & & $(0,0156)$ & & $(0,0041)$ & $(0,0040)$ \\
\hline
\end{tabular}

( ) erro padrão

A porcentagem de indivíduos que compartilham genótipos cloroplastidiais idênticos (grupo LM) variou de $2,37 \%$ na população B a 6,69\% na população D (Tabela 13). A proporção de pares de indivíduos com genótipos idênticos não teve relação direta com a estimativa da coancestralidade nesse grupo. Embora cerca de $7 \%$ dos indivíduos das populações C e D compartilhassem genótipos cloroplastidiais idênticos, a estimativa de coancestralidade entre os indivíduos desse grupo foi variável. Enquanto na população $\mathrm{D}$ a coancestralidade foi elevada $\left(\hat{\theta}_{x y}=0,1796 \pm 0,0219\right)$, na população C e nas demais ela não diferiu estatisticamente de zero. A diferença entre a população D e as demais pode ser melhor visualizada na Figura 11. 


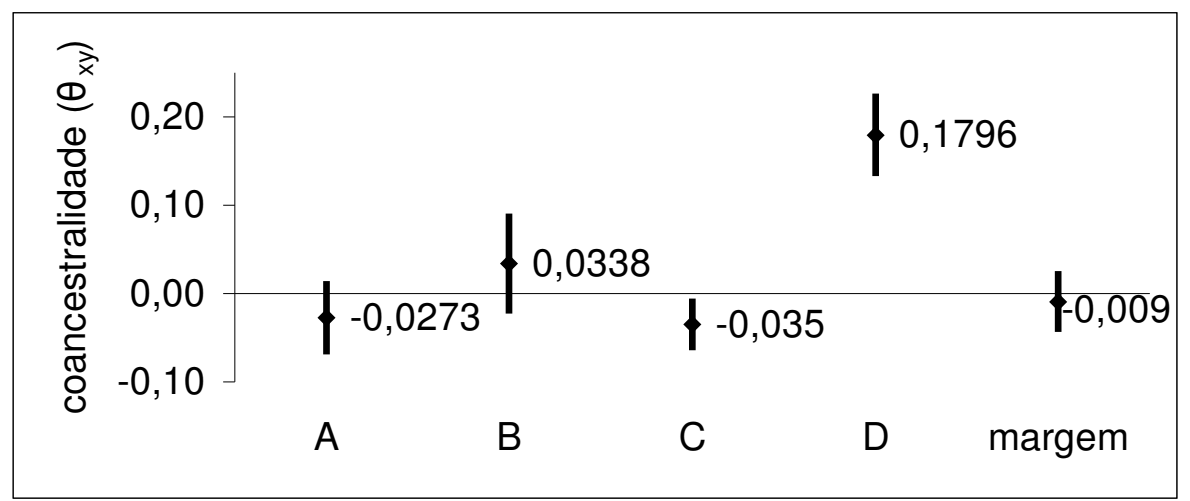

Figura 11 - Coancestralidade média no grupo de indivíduos que compartilham genótipos cloroplastidiais idênticos (grupo LM) nas quatro populações naturais e nos indivíduos amostrados na margem da estrada. Intervalo de confiança obtido por $1,96 \times$ erro padrão

\subsection{Estrutura genética}

\subsubsection{Marcadores microssatélites nucleares}

Como os indivíduos na margem da estrada que interliga as populações A, B e C têm origem antrópica mais recente e diferenciada das populações naturais, esse grupo de indivíduos não pode ser considerado como tendo uma história evolutiva comum às populações naturais. Devido a isso, as plantas coletadas na margem da estrada foram excluídas das análises de estrutura genética por variância das freqüências alélicas.

O loco CA53 foi o que apresentou valores mais elevados de índice de fixação total das populações $(\hat{F}=0,455)$ e índice de fixação médio dentro das populações $(\hat{f}=0,440)$ (Tabela 14). Embora o intervalo de confiança tenha sido amplo, o valor médio do $\hat{f}(0,078)$ não diferiu estatisticamente de zero, o que indica que a maior parcela da endogamia total ( $\hat{F}=0,127$ ) encontra-se entre as populações, e, portanto, é efeito da deriva genética e de desvios dos cruzamentos aleatórios dentro das populações. A divergência genética entre as populações $\left(\hat{\theta}_{p}\right)$ foi significativa e de cerca de 5,35\%. Ao considerar apenas as populações geograficamente mais próximas (A, B e 
C), a estimativa do $\hat{\theta}_{p}(0,002)$ não diferiu estatisticamente de zero. A estimativa nula de divergência genética entre as populações $A, B$ e $C$ indica que as mesmas constituíam uma única população panmítica antes da fragmentação do cerrado. Como atualmente a vegetação de cerrado na região é descontínua, pode-se considerá-las como subpopulações. Embora o valor do $\hat{R}_{S T}(0,032)$ tenha sido ligeiramente inferior ao $\hat{\theta}_{p}(0,053)$, essas duas estimativas não diferiram estatisticamente entre si, já que os intervalos de confiança se sobrepõem.

Tabela 14. Estatísticas de estrutura genética em quatro populações naturais de $S$. lycocarpum. $\hat{f}$ =índice de fixação médio dentro das populações; $\hat{F}=$ índice de fixação total das populações; $\hat{\theta}_{P}=$ divergência genética entre populações; $\hat{R}_{S T}=$ divergência genética entre populações (Goodman, 1997)

\begin{tabular}{lcccc}
\hline LOCO & $\hat{f}$ & $\hat{F}$ & $\hat{\theta}_{p}$ & $\hat{R}_{S T}$ \\
\hline CA 23 & $-0,0685$ & 0,0836 & 0,1424 & 0,1427 \\
CA 53 & 0,4402 & 0,4547 & 0,0260 & $-0,0005$ \\
CA 144 & 0,1117 & 0,1154 & 0,0043 & 0,0052 \\
CA158 & 0,1209 & 0,398 & 0,0214 & $-0,0007$ \\
CA 161 & $-0,0051$ & $-0,0047$ & 0,0004 & 0,0116 \\
Média & 0,0776 & 0,1271 & 0,0535 & 0,0317 \\
${\text { (I.C. })^{1}}^{1}$ & $(-0,0665$ a 0,3131) & $(0,0784$ a 0,3260) & $(0,0039$ a 0,1394) & $(0,0255$ a 0,0598$)$
\end{tabular}

1 Intervalo de confiança a 99\% obtido por 10.000 reamostragens "bootstrap" sobre locos

\subsubsection{Marcadores cloroplastidiais}

Assim como feito para marcadores nucleares, para estimativas dos parâmetros de estrutura genética foram consideradas apenas as populações A, B, C e D. Tanto a 
diversidade gênica total $\left(\hat{H}_{T}=0,979\right)$ como a diversidade intrapopulacional ( $\left.\hat{H}_{S}=0,947\right)$ apresentaram estimativas elevadas. O coeficiente de diferenciação gênica $\left(\hat{G}_{S T}=0,032\right)$ foi baixo, indicando que 3,2\% da diversidade gênica está distribuída entre as populações. Aparentemente, parece um contra-senso a divergência ter sido baixa e ainda inferior à obtida para os locos nucleares. Como o número de haplótipos privados foi elevado em todas as populações, esperar-se-ia que as populações fossem mais divergentes. Entretanto, como discutido por Hedrick (1999), quanto maior o número de alelos, mais as estimativas de diversidade gênica total e intrapopulacional $\left(\hat{H}_{T}\right.$ e $\hat{H}_{S}$ ) se aproximam da unidade e, como conseqüência, menor é o $\hat{G}_{S T}$. Petit et al. (2005) observaram uma significativa correlação negativa entre $\hat{G}_{S T}$ e número de haplótipos. A divergência genética obtida pelo método da variância das freqüências alélicas também foi reduzida $\left(\hat{\theta}_{p_{C}}=0,042 \pm 0,0159\right)$. Comparando-se os intervalos de confiança das estimativas de $\hat{\theta}_{p}$ por marcadores nucleares e cloroplastidiais, conclui-se que essas não diferem estatisticamente entre si.

\subsection{Fluxo gênico}

A estimativa indireta do fluxo gênico calculada com os dados de microssatélites nucleares foi de 4,42 migrantes por geração, enquanto que o fluxo gênico obtido com marcadores cloroplastidiais foi de 11,40 migrantes por geração. A razão de fluxo gênico $\left(m_{p} / m_{s}\right)$, obtida com a eq. (8) (item 3.5.8), para o conjunto das quatro populações foi 1,22; mostrando que, nessa escala de estudo, a contribuição da migração de pólen no fluxo gênico total foi praticamente semelhante à migração de sementes. A razão de fluxo gênico inferior a cinco $\left(m_{p} / m_{s}<5\right)$ indica que a migração de sementes desempenha um papel significativo no fluxo gênico total (Petit et al., 2005).

A comparação da razão de fluxo gênico entre todos os pares de populações (Tabela 15) mostra que a migração de pólen foi cerca de cinco vezes maior que a 
migração de sementes a uma distância de 20 a 40 Km, mas que a maiores distâncias, a contribuição da migração de semente no fluxo gênico total tornou-se mais significativa.

A estimativa de $F_{S T_{N}}$ entre as populações A e B foi negativa $\left(F_{S T_{N}}=-0,0033\right)$, indicando que a divergência entre os indivíduos dentro de cada população foi superior à divergência entre as duas populações. Um valor de $F_{S T}$ inferior a zero significa que o fluxo gênico entre essas populações tende ao infinito e que a contribuição da migração de pólen no fluxo gênico total é infinitamente superior à migração de sementes.

Tabela 15. Razão de migração de pólen e sementes entre pares de populações. $F_{S T_{N}}=F_{S T}$ calculado por marcadores nucleares; $F_{S T_{C}}=F_{S T}$ obtido por marcadores cloroplastidiais; $\hat{M}_{N}$ e $\hat{M}_{C}=$ fluxo gênico entre pares de populações com marcadores nucleares e cloroplastidiais, respectivamente; e $m_{p} / m_{s}=$ razão da migração de pólen e sementes

\begin{tabular}{ccccccc}
\hline $\begin{array}{c}\text { Pares de } \\
\text { Populações }\end{array}$ & $\begin{array}{c}\text { Distância } \\
(\mathrm{km})\end{array}$ & $\hat{F}_{S T_{N}}$ & $\hat{F}_{S T_{C}}$ & $\hat{M}_{N}$ & $\hat{M}_{C}$ & $m_{p} / m_{s}$ \\
\hline A/B & 19,21 & $-0,0033$ & 0,0067 & - & 74,13 & - \\
B/C & 24,19 & 0,0041 & 0,0288 & 60,72 & 16,86 & 5,20 \\
A/C & 43,08 & 0,0048 & 0,0362 & 51,83 & 13,31 & 5,79 \\
A/D & 110,15 & 0,1135 & 0,0572 & 1,95 & 8,24 & 1,53 \\
B/D & 118,82 & 0,1146 & 0,0538 & 1,93 & 8,79 & 1,56 \\
C/D & 127,99 & 0,0951 & 0,0751 & 2,37 & 6,16 & 1,23 \\
\hline
\end{tabular}

\subsection{Teste do isolamento pela distância}

O teste do isolamento pela distância mostrou uma correlação negativa forte e estatisticamente significativa entre os logaritmos do fluxo gênico e das distâncias geográficas entre pares de populações, tanto para microssatélites nucleares como para os marcadores cloroplastidiais (Figura 12). A correlação indica que as populações estão em equilíbrio entre deriva e fluxo gênico e que o fluxo gênico atual resulta em um 
padrão de isolamento pela distância, em que a diferenciação genética entre as populações aumenta com a distância geográfica. A inclinação mais acentuada indica o quão rápido o fluxo gênico declina com a distância. A menor inclinação da reta para marcadores cloroplastidiais indica que há menores restrições à dispersão em longas distâncias para sementes.
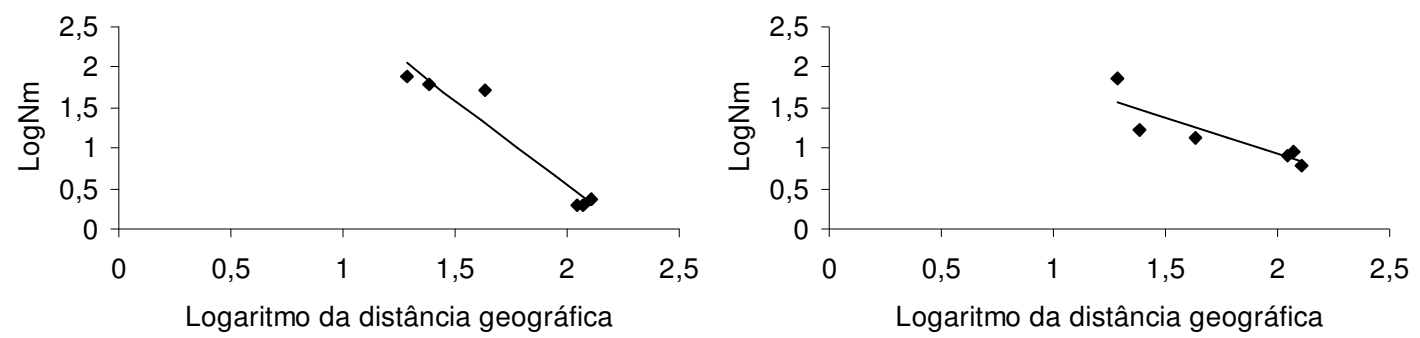

Figura 12 - Teste do isolamento pela distância para microssatélites nucleares (à esquerda) ( $r=-0,963 ; p=0,043)$ e cloroplastidiais (à direita) ( $r=-0872$; $p=0,051)$

\subsection{Colonização na margem da estrada}

\subsubsection{Teste de maternidade}

Nos testes de maternidade para as plantas à margem da estrada, foram consideradas como prováveis mães apenas os indivíduos amostrados nas populações $A$, B e C. O poder de exclusão médio, considerando todos os locos nucleares e cloroplastidiais, foi 0,863. Identificaram-se as possíveis mães de 26 (43,3\%) plantas amostradas na margem da estrada com $80 \%$ de confiabilidade. Em $50 \%$ dos casos, as prováveis mães eram da população C, em 30,8\% da população B e em 19,2\% da população $A$. Essas porcentagens indicam que a população $C$ contribuiu mais para a colonização da margem da estrada que as outras duas populações. O valor do $\Delta_{C}$ foi 0,31, considerando o intervalo de confiança de $80 \%$. Dessa forma, as combinações mãe-filho com $\Delta$ superior a 0,31 foram consideradas as mais prováveis mães com $80 \%$ de segurança (Tabela 16). 
Tabela 16. Identificação das prováveis mães das plantas amostradas na margem da estrada com os respectivos "LOD-score" e $\Delta$

\begin{tabular}{|c|c|c|c|c|}
\hline $\begin{array}{l}\text { Planta da } \\
\text { margem }\end{array}$ & Provável mãe & LOD & $\Delta$ & $\begin{array}{c}\text { Distância } \\
\text { geográfica }^{1}(\mathrm{~km})\end{array}$ \\
\hline & \multicolumn{4}{|l|}{ População A (5) } \\
\hline D-6 & $A-46$ & 2,7320 & 0,7310 & 42,18 \\
\hline D-9 & $A-5$ & 2,2779 & 0,4828 & 38,58 \\
\hline D-19 & $A-46$ & 2,7320 & 0,7310 & 27,41 \\
\hline D-55 & $A-5$ & 3,2446 & 1,3950 & 4,82 \\
\hline D-59 & $A-13$ & 4,6952 & 2,2117 & 0,90 \\
\hline \multirow[t]{2}{*}{ média } & - & - & - & 27,78 \\
\hline & \multicolumn{4}{|l|}{ População B (8) } \\
\hline D-5 & B-38 & 3,2499 & 0,4384 & 23,04 \\
\hline D-14 & B-30 & 6,2399 & 1,6733 & 12,88 \\
\hline D-15 & B-50 & 4,4913 & 0,7111 & 11,92 \\
\hline D-22 & B-39 & 2,7127 & 0,3368 & 7,61 \\
\hline D-23 & B-57 & 3,6328 & 1,1294 & 6,97 \\
\hline D-31 & B-7 & 4,4251 & 0,6589 & 0,77 \\
\hline D-38 & B-13 & 3,4608 & 0,8906 & 4,08 \\
\hline D-44 & B-51 & 2,7584 & 0,3253 & 9,36 \\
\hline \multirow[t]{2}{*}{ média } & - & - & - & 17,36 \\
\hline & \multicolumn{4}{|l|}{ População C (13) } \\
\hline D-7 & $C-23$ & 4,8429 & 0,8759 & 3,23 \\
\hline D-8 & $C-36$ & 2,9695 & 0,5669 & 4,16 \\
\hline D-24 & $C-34$ & 2,4966 & 0,3556 & 19,39 \\
\hline D-27 & $C-34$ & 2,1482 & 0,4208 & 21,93 \\
\hline D-28 & $C-10$ & 4,3743 & 1,0690 & 22,80 \\
\hline D-32 & $C-14$ & 4,5089 & 0,6876 & 23,57 \\
\hline D-36 & $C-21$ & 4,7295 & 0,3427 & 23,04 \\
\hline D-37 & $C-2$ & 3,7991 & 0,3321 & 23,55 \\
\hline D-48 & C-41 & 3,4414 & 0,7784 & 34,56 \\
\hline D-51 & C-6 & 3,8952 & 0,3788 & 36,79 \\
\hline D-54 & $C-26$ & 2,6187 & 0,6269 & 38,52 \\
\hline D-58 & $C-35$ & 3,8294 & 0,6069 & 42,01 \\
\hline D-60 & C-25 & 3,6507 & 0,5663 & 42,65 \\
\hline média & - & - & - & 23,55 \\
\hline
\end{tabular}

${ }^{1}$ distância da planta em relação à população natural em foi detectada a mãe

Não foi observada uma relação de proximidade entre a população de origem da mãe e a localização do provável filho. As distâncias de migração foram variáveis (770 metros a 42,65km), tanto que apesar da distância média de migração ter sido de $20,26 \mathrm{~km}$, o desvio-padrão foi elevado $( \pm 14,26)$. 
Ainda que atualmente as áreas adjacentes ao fragmento em que foi coletada a população $C$ sejam mais antrópicas em relação às áreas de coleta das populações $A$ e B, apresentando a rodovia asfaltada GO 219 e extensas monoculturas, a população C não se encontra isolada de áreas de vegetação preservada. Registrou-se, nesta população, a presença de fezes de lobo-guará contendo sementes de $S$. lycocarpum, o que demonstra que a fauna visita a área em busca de alimento e dispersa sementes nas áreas de entorno (Figura 13). Essa população aparenta ser mais antiga que as populações $A$ e $B$. Foi observado na população $C$ um número proporcionalmente maior de plantas de grande porte e apresentando muitos frutos. Esse é um indício que, historicamente, essa população foi mais freqüentemente visitada por animais que buscavam frutos como alimento e dispersavam as sementes nas margens das estradas.

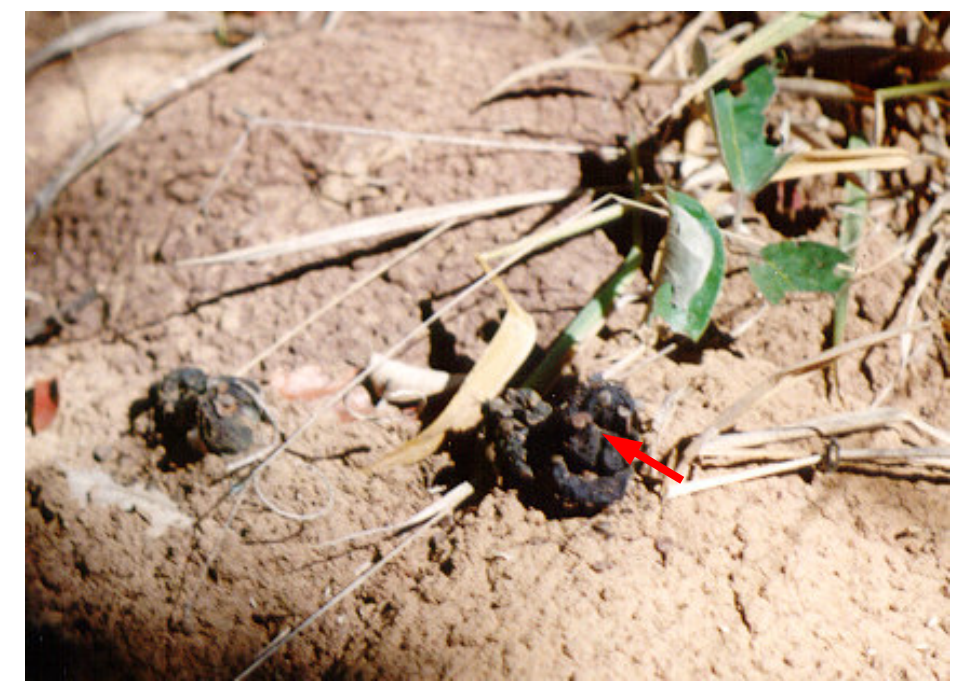

Figura 13 - Fezes de lobo-guará sobre um sauveiro contendo sementes de $S$. lycocarpum (seta vermelha)

\subsubsection{Distâncias genéticas}

A partir do agrupamento UPGMA das distâncias genéticas de Nei, estimadas com os genótipos cloroplastidiais, foi possível visualizar que a margem da estrada é mais semelhante geneticamente à população C (Figura 14). O dendrograma ilustra 0 
que já foi observado por meio dos testes de maternidade: a população $C$ contribuiu com mais sementes para a colonização da margem da estrada que as outras populações amostradas e não há relação de distância de migração entre as populações A, B e C e margem da estrada.
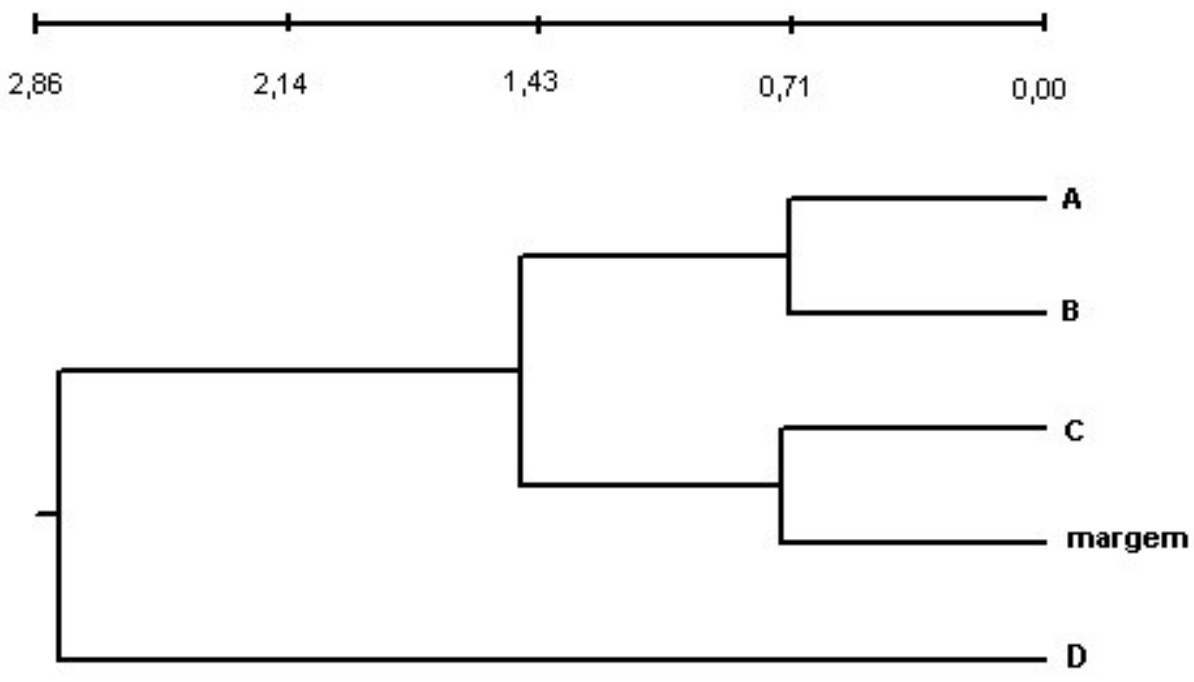

Figura 14 - Padrão de divergência genética entre quatro populações (A, B, C e D) naturais de $S$. lycocarpum e o grupo formado pelas plantas coletadas na margem da estrada que interliga as populações A, B e C. Dendrograma definido pelo método de agrupamento UPGMA e baseado na distância genética de Nei (1972) com marcadores cloroplastidiais

\subsection{Sistema de reprodução}

O sistema de reprodução foi inicialmente abordado pelo teste de EHW. O teste exato de Fisher revelou desvios das freqüências genotípicas observadas em relação às esperadas pelo modelo no loco CA158 apenas nas progênies das populações B e C (Tabela 17). Desvios das proporções de Hardy-Weinberg podem ser causados pelo sistema de reprodução ou pela ocorrência de seleção, migração, deriva genética ou mutação. 
Tabela 17. Probabilidades exatas (Teste Exato de Fisher) dos desvios das proporções de Hardy-Weinberg em cada loco microssatélite nuclear nas populações

\begin{tabular}{lcccccc}
\hline & \multicolumn{2}{c}{ População A } & \multicolumn{2}{c}{ População B } & \multicolumn{2}{c}{ População C } \\
& Matrizes & Progênies & Matrizes & Progênies & Matrizes & Progênies \\
\hline CA23 & 1,00000 & 0,40469 & 1,00000 & 0,50031 & 1,00000 & 0,29906 \\
CA 53 & 1,00000 & 1,00000 & 1,00000 & 0,29875 & 1,00000 & 1,00000 \\
CA144 & 1,00000 & 1,00000 & 1,00000 & 1,00000 & 1,00000 & 0,57598 \\
CA 158 & 1,00000 & 0,75812 & 0,41125 & $0,04281^{*}$ & 1,00000 & $0,00000 * *$ \\
CA161 & 1,00000 & 1,00000 & 1,00000 & 1,00000 & 1,00000 & 1,00000 \\
CA 88 & 1,00000 & 1,00000 & 1,00000 & 1,00000 & 1,00000 & 1,00000 \\
\hline
\end{tabular}

$* p<0,05 ; * * p<0,01$

A divergência genética entre as freqüências alélicas dos conjuntos de óvulo e pólen foi observada apenas para o loco CA158 nas populações A e C (Tabela 18). Como a amostragem nessas duas populações foi reduzida, acredita-se que essa divergência seja resultante da baixa representatividade das árvores maternas. Com o pequeno número de árvores maternas amostradas, a representatividade alélica no conjunto de óvulo tornou-se muito inferior ao conjunto de pólen. Esse efeito é ainda maior em locos multialélicos como o CA 158. Na população A, por exemplo, apenas duas árvores maternas foram amostradas, sendo que ambas apresentavam o mesmo genótipo para o loco CA 158. Na população C, a divergência entre pólen e óvulo para esse loco foi ainda mais acentuada. Isso ocorreu porque alelos freqüentes no conjunto de pólen não foram observados no conjunto de óvulos. 
Tabela 18. Estimativas das freqüências gênicas dos conjuntos de óvulo e pólen, nas populações A, B e C. $\hat{F}_{S T}=$ divergência genética entre os conjuntos de pólen e óvulo

\begin{tabular}{|c|c|c|c|c|c|c|c|c|c|c|c|c|c|c|c|c|}
\hline \multirow[b]{2}{*}{ Loco } & \multirow[b]{2}{*}{ Alelo } & \multicolumn{5}{|c|}{ População A } & \multicolumn{5}{|c|}{ População B } & \multicolumn{5}{|c|}{ População C } \\
\hline & & Pólen & Óvulo & $\hat{F}_{S T}$ & g.l. & $\chi^{2}$ & Pólen & Óvulo & $\hat{F}_{S T}$ & g.l. & $\chi^{2}$ & Pólen & Óvulo & $\hat{F}_{S T}$ & g.l. & $\chi^{2}$ \\
\hline \multirow[t]{2}{*}{ CA23 } & 1 & 0,456 & 0,250 & & & & 0,462 & 0,444 & & & & 0,624 & 0,500 & & & \\
\hline & 2 & 0,544 & 0,750 & 0,046 & 1 & 1,11 & 0,538 & 0,556 & 0,00 & 1 & 0,05 & 0,376 & 0,500 & 0,016 & 1 & 1,00 \\
\hline \multirow[t]{2}{*}{ CA53 } & 1 & 0,063 & 0,000 & & & & 0,027 & 0,056 & & & & - & - & & & \\
\hline & 2 & 0,937 & 1,000 & 0,033 & 1 & 0,78 & 0,973 & 0,944 & 0,005 & 1 & 0,08 & 1,000 & 1,000 & 0,000 & 0 & - \\
\hline \multirow[t]{2}{*}{ CA144 } & 1 & 0,914 & 0,750 & & & & 0,867 & 0,778 & & & & 0,791 & 0,833 & & & \\
\hline & 2 & 0,086 & 0,250 & 0,048 & 1 & 1,15 & 0,133 & 0,222 & 0,014 & 1 & 2,09 & 0,209 & 0,167 & 0,003 & 1 & 0,18 \\
\hline \multirow[t]{15}{*}{ CA158 } & 1 & - & - & & & & 0,013 & 0,000 & & & & - & - & & & \\
\hline & 4 & - & - & & & & 0,006 & 0,000 & & & & - & - & & & \\
\hline & 5 & - & - & & & & 0,013 & 0,000 & & & & - & - & & & \\
\hline & 6 & 0,354 & 0,500 & & & & 0,292 & 0,333 & & & & 0,381 & 0,000 & & & \\
\hline & 7 & - & - & & & & 0,045 & 0,000 & & & & 0,088 & 0,333 & & & \\
\hline & 8 & 0,031 & 0,000 & & & & 0,197 & 0,167 & & & & 0,133 & 0,000 & & & \\
\hline & 9 & 0,063 & 0,000 & & & & 0,123 & 0,167 & & & & 0,067 & 0,167 & & & \\
\hline & 10 & 0,270 & 0,500 & & & & 0,033 & 0,056 & & & & 0,096 & 0,167 & & & \\
\hline & 11 & 0,063 & 0,000 & & & & 0,064 & 0,000 & & & & 0,149 & 0,000 & & & \\
\hline & 12 & 0,031 & 0,000 & & & & 0,025 & 0,000 & & & & 0,053 & 0,167 & & & \\
\hline & 13 & - & - & & & & 0,126 & 0,167 & & & & 0,000 & 0,167 & & & \\
\hline & 14 & 0,188 & 0,000 & & & & 0,063 & 0,056 & & & & - & - & & & \\
\hline & 15 & - & - & & & & - & - & & & & 0,017 & 0,000 & & & \\
\hline & 19 & - & - & & & & 0,000 & 0,056 & & & & - & - & & & \\
\hline & 20 & - & - & 0,045 & 6 & $13,1^{*}$ & - & - & 0,005 & 12 & 18,6 & 0,017 & 0,000 & 0,088 & 9 & $102,0^{* *}$ \\
\hline \multirow[t]{3}{*}{ CA161 } & 2 & 0,969 & 1,000 & & & & 1,000 & 1,000 & & & & 1,000 & 0,833 & & & \\
\hline & 5 & 0,031 & 0,000 & & & & - & - & & & & 0,000 & 0,167 & & & \\
\hline & 6 & - & - & 0,091 & 1 & 2,19 & - & - & 0,000 & 0 & - & - & - & 0,016 & 1 & 1,01 \\
\hline
\end{tabular}


As estimativas de taxa de cruzamento multiloco $\left(\hat{t}_{m}\right)$ foram próximas da unidade em quase todas as famílias, indicando que $S$. lycocarpum reproduz-se predominantemente por cruzamentos. Apesar da variação entre famílias, observa-se que naquelas em que o valor de $\hat{t}_{m}$ foi inferior a 0,80 , os erros-padrão foram elevados (Tabela 19). As menores estimativas individuais foram observadas na população $A$, tanto que a estimativa média de taxa de cruzamento multiloco $\left(\hat{t}_{m}\right)$ foi $0,768( \pm 0,053)$ e uniloco $\left(\hat{t}_{s}\right)$ foi $0,753( \pm 0,044)$ (Tabela 20$)$. Acredita-se que esta diferença deva-se principalmente à amostragem, que foi muito reduzida na população A (24 progênies em duas matrizes).

Tabela 19. Taxa individual de cruzamento multiloco por progênie

\begin{tabular}{|c|c|c|c|c|c|}
\hline Matrizes & Progênies & $\hat{t}_{m}$ & Matrizes & Progênies & $\hat{t}_{m}$ \\
\hline Fam A1 & 17 & $0,826(0,137)$ & Fam B8 & 08 & $0,984(0,002)$ \\
\hline Fam A4 & 07 & $0,722(0,178)$ & Fam B9 & 18 & $0,897(0,109)$ \\
\hline Fam B1 & 40 & $1,000(0,000)$ & Fam B10 & 06 & $0,996(0,005)$ \\
\hline Fam B2 & 07 & $0,968(0,038)$ & Fam B12 & 25 & $0,772(0,184)$ \\
\hline Fam B5 & 11 & $0,989(0,019)$ & Fam C1 & 29 & $0,970(0,045)$ \\
\hline Fam B6 & 31 & $1,000(0,000)$ & Fam C3 & 28 & $0,840(0,097)$ \\
\hline Fam B7 & 08 & $0,983(0,009)$ & Fam C5 & 07 & $1,000(0,000)$ \\
\hline
\end{tabular}

( ) Erro padrão da média, obtido por 500 reamostragens "bootstrap" dentro de famílias

As populações B e C apresentaram estimativas médias de taxa de cruzamento multiloco superiores ao observado na população A (Tabela 20). De modo geral, todos os parâmetros de sistema de reprodução para as populações B e C foram semelhantes. As estimativas médias de taxa de cruzamento multiloco $\left(\hat{t}_{m}\right)$ e uniloco $\left(\hat{t}_{s}\right)$ praticamente não diferiram entre si nas três populações, o que mostra que os cruzamentos entre parentes $\left(\hat{t}_{m}-\hat{t}_{s}\right)$ não são comuns. As correlações de paternidade foram baixas. Para a população $B$, por exemplo, apenas 9,8\% das progênies são resultantes do mesmo parental masculino $\left(\hat{r}_{p}=0,098\right)$. 
Com as correlações de paternidade, foi possível obter o número médio de árvores que participou como doadora de pólen nos cruzamentos. Nas populações B e C esse número foi superior a 10 . Na população $A$, o número médio de doadores de pólen foi excessivamente elevado $(47,62)$, quase o correspondente ao tamanho amostral da população adulta (Tabela 20). Esse valor é irreal, sendo um viés da estimativa decorrente do reduzido tamanho amostral.

Tabela 20. Estimativas de parâmetros do sistema de reprodução em três populações de S. lycocarpum

\begin{tabular}{lccc}
\hline Populações & $\mathrm{A}$ & $\mathrm{B}$ & $\mathrm{C}$ \\
Famílias (progênies) & $02(24)$ & $09(154)$ & $03(64)$ \\
\hline Taxa de cruzamento multiloco $\left(\hat{t}_{m}\right)$ & $0,768(0,053)$ & $1,000(0,003)$ & $0,956(0,026)$ \\
Taxa de cruzamento uniloco $\left(\hat{t}_{s}\right)$ & $0,753(0,044)$ & $0,969(0,021)$ & $0,920(0,047)$ \\
Taxa de cruzamento biparental $\left(\hat{t}_{m}-\hat{t}_{s}\right)$ & $0,014(0,010)$ & $0,031(0,020)$ & $0,036(0,022)$ \\
Correlação de paternidade $\left(\hat{r}_{p}\right)$ & $0,021(0,001)$ & $0,098(0,017)$ & $0,087(0,024)$ \\
Correlação de autofecundação $\left(\hat{r}_{s}\right)$ & $0,009(0,001)$ & $0,107(0,001)$ & $0,054(0,005)$ \\
№ médio de doadores de pólen $\left(1 / \hat{r}_{P}\right)$ & 47,62 & 10,20 & 11,49 \\
Proporção de irmãos de autofecundação & $23,20 \%$ & $0,00 \%$ & $4,40 \%$ \\
$\left(\hat{P}_{I A}=\hat{s}\right)$ & & & \\
Proporção de irmãos-completos & $1,61 \%$ & $9,80 \%$ & $8,32 \%$ \\
$\left(\hat{P}_{I C}=\hat{t}_{m} \hat{r}_{p}\right)$ & & & $87,28 \%$ \\
Proporção de meios-irmãos & $75,19 \%$ & $90,20 \%$ & \\
$\left(\hat{P}_{M I}=\hat{t}_{m}\left(1-\hat{r}_{p}\right)\right)$ & & & 0,077 \\
Índice de fixação nos adultos $(\hat{F})$ & 0,214 & $-0,006$ & $-0,062$ \\
& {$[0,000$ a 0,814$]$} & {$[-0,067$ a 0,052$]$} & {$[-0,094$ a 0,170$]$} \\
Índice de fixação nas progênies $\left(\hat{F}_{p}\right)$ & $-0,098$ & $-0,036$ & {$[-0,156$ a 0,008$]$} \\
\hline
\end{tabular}

[ ] Intervalo de confiança a $99 \%$ de probabilidade, obtido por 10.000 reamostragens "bootstrap" sobre locos

( ) Erro padrão da média, obtido por 500 reamostragens "bootstrap" sobre famílias

Com as estimativas de $\hat{t}_{m}$ e $\hat{r}_{p}$ foi possível calcular as proporções de irmãos de autofecundação, irmãos completos e meios-irmãos nas progênies (Tabela 20). Essas proporções constituem-se em representações mais visualizáveis das observações discutidas anteriormente. As proporções de meios-irmãos foram de cerca de $90 \%$ nas 
populações $\mathrm{B}$ e C e, como conseqüência das reduzidas correlações de paternidade, a proporção de irmãos completos foi de cerca de $10 \%$. As autofecundações também foram insignificantes nessas duas populações. Os índices de fixação em adultos e em progênies são estaticamente não diferentes de zero nas três populações e corroboram as probabilidades exatas do teste de EHW.

\subsection{Estimadores para estratégias de conservação}

\subsection{1 Área mínima viável para conservação in situ}

Como em geral os níveis de endogamia foram muito reduzidos, com exceção do observado na população $\mathrm{A}$, o tamanho efetivo populacional $\left(\hat{N}_{e}\right)$ foi muito próximo ao tamanho amostral (Tabela 21). Com base na densidade populacional estimada para cada população foi possível calcular a área necessária para reter um tamanho efetivo de 500. De modo geral, como o tamanho efetivo foi praticamente semelhante ao tamanho amostral, o tamanho estimado de reserva genética foi cerca de 10 vezes maior que a área amostrada nesse estudo. Ao considerar o $N_{e(r e f)}=1000$ para conservação em longo prazo, a área mínima viável deve ser o praticamente o dobro da área necessária para reter o tamanho efetivo de 500.

Tabela 21. Estimativas populacionais para conservação in situr: $n=$ tamanho amostral; $\hat{N}_{e}=$ Tamanho efetivo populacional; $d=$ densidade populacional em plantas por ha; $\mathrm{AE}=$ área estimada de cada fragmento; $\mathrm{AMV}_{500}=$ área necessária para reter $N_{e(r e f)}=500$

\begin{tabular}{ccccccc}
\hline População & $n$ & $\hat{f}$ & $\hat{N}_{e}$ & $d$ & $\mathrm{AE}(\mathrm{ha})$ & AMV $_{500}$ (ha) \\
\hline A & 58 & 0,214 & 47,77 & 3,92 & 500 & 159,11 \\
B & 60 & $-0,006$ & 60,36 & 4,83 & 50 & 102,90 \\
C & 60 & 0,077 & 55,71 & 12,2 & 50 & 44,14 \\
D & 55,33 & 0,083 & 55,24 & 2,50 & 217 & 200,32 \\
\hline
\end{tabular}




\subsubsection{Número de populações a serem conservadas}

De acordo com o demonstrado por Vencovsky \& Crossa (1999), é possível determinar o número de populações que devem ser conservadas para reter um tamanho efetivo de 500. Como $S$. lycocarpum é uma espécie que está presente em elevada densidade nas regiões adjacentes às áreas de coleta das populações naturais, ocupando praticamente toda a extensão da área de estudo, pode-se considerar o número de populações na região como infinito. Dessa forma, o número de populações que devem ser conservadas é dependente apenas do valor do $\hat{\theta}_{p}$, ou seja, da divergência genética entre as populações $\left(N_{e}=S /\left(2 \times \hat{\theta}_{p}\right)\right.$ em que $S$ é o número de populações) . Aplicando-se a eq. (13) (item 3.5.12.2), na escala geográfica de estudo, cerca de 54 populações de $S$. lycocarpum devem ser conservadas para reter um tamanho efetivo de 500.

\subsubsection{Número de matrizes para coleta de sementes}

A partir do coeficiente de parentesco $\left(\hat{r}_{x y}\right)$ calculado para as progênies (Tabela 21), obteve-se o coeficiente de coancestralidade $(\hat{\theta})$. As estimativas de coancestralidade dentro de progênies apresentaram valores próximos ao esperado em progênies de meios-irmãos ( $\hat{\theta}=0,125)$, especialmente nas populações $B(\hat{\theta}=0,137)$ e C $(\hat{\theta}=0,138)$, em que a proporção de meios irmãos foi de cerca de $90 \%$ (Tabela 20). Essas estimativas de coancestralidade, obtidas a partir do coeficiente de parentesco com uso da eq. 9 (item 3.5.11) foram semelhantes às estimativas obtidas a partir do método proposto por Lynch \& Ritland (1999), apresentadas na Tabela 12 (item 4.8). A semelhança entre as estimativas mostra que ambos os procedimentos dão resultados confiáveis. 
Com a estimativa de tamanho efetivo de variância $\left(\hat{N}_{e(v)}\right)$ obtida pela eq. 14 (item 3.5.12.3), calculou-se o número mínimo de matrizes que devem ser consideradas na coleta de sementes para conservação ex situ. Desejando-se a manutenção da variabilidade genética em curto prazo, em média deve-se coletar sementes de 30 a 40 matrizes para manter um tamanho efetivo de 100 (41, 34 e 29 matrizes para as populações $A, B$ e $C$, respectivamente). Se o interesse é a conservação em longo prazo, é necessário coletar sementes de 205, 166 e 144 matrizes das populações A, B e C para manter um tamanho efetivo de 500 (Tabela 22).

Tabela 22. Número mínimo de matrizes $S$. lycocarpum para coleta de sementes obtido com os dados das progênies

\begin{tabular}{lccc}
\hline Populações & A & B & C \\
Famílias (progênies) & $02(24)$ & $09(154)$ & $03(64)$ \\
\hline Coeficiente de parentesco $\left(\hat{r}_{x y}\right)$ & 0,383 & 0,274 & 0,277 \\
Coancestralidade dentro de progênies $(\hat{\theta})$ & 0,192 & 0,137 & 0,138 \\
Tamanho efetivo de variância $\left(\hat{N}_{e(v)}\right)$ & 2,44 & 3,01 & 3,48 \\
No de matrizes para reter o $\hat{N}_{e}=100(\hat{m})$ & 41 & 34 & 29 \\
No de matrizes para reter o $\hat{N}_{e}=500(\hat{m})$ & 205 & 166 & 144 \\
\hline
\end{tabular}

Como já discutido no capítulo de autocorrelação espacial dos genótipos, deve-se coletar sementes de plantas situadas a mais de $50 \mathrm{~m}$ umas das outras, para que a amostragem de genótipos parentes seja evitada. Como sugerido por Vencovsky (1987), deve-se coletar mesmo número de sementes por matriz (controle gamético feminino) para a maximização do tamanho efetivo. 


\section{DISCUSSÃO}

\subsection{Amplificação heteróloga}

O polimorfismo nos marcadores nucleares foi baixo, resultando em estimativas de diversidade genética inferiores às esperadas para o tipo de marcador molecular utilizado. O número médio de alelos por loco foi $\hat{A}=3,88( \pm 0,15)$ e a diversidade gênica foi $\hat{H}_{e}=0,330( \pm 0,013)$. O mesmo pôde ser observado em um estudo realizado com outra espécie frutífera do Cerrado, Eugenia dysenterica, o qual avaliou a diversidade genética com uso de sete locos microssatélites desenvolvidos para Eucalyptus sp. No estudo com E. dysenterica (Zucchi et al., 2003), as estimativas de diversidade gênica foram superiores $\left(\hat{H}_{e}=0,458\right)$ ao observado em $S$. Iycocarpum, ainda que o número médio de alelos por loco $(\hat{A}=3,12)$ tenha sido semelhante. Por outro lado, em um estudo com Caryocar brasiliense com iniciadores microssatélites desenvolvidos para a própria espécie (Collevatti et al., 2001b), a diversidade gênica $\left(\hat{H}_{e}=0,856\right)$ e o número médio de alelos por loco $(\hat{A}=10,6)$ foram semelhantes ao esperado em estudos com marcadores microssatélites.

Embora alguns locos já apresentassem pequeno número de alelos em Capsicum spp, acredita-se que o baixo polimorfismo em $S$. lycocarpum seja devido ao fato desses iniciadores terem sido desenvolvidos para outro gênero (Capsicum). Estudos comparativos entre locos microssatélites homólogos em diferentes espécies mostram que tanto o polimorfismo, quanto o tamanho dos alelos tendem a ser maiores na espécie em que os locos foram primeiramente caracterizados (espécie focal) (Jarne \& Lagoda, 1996). 
Ainda que não haja um consenso para explicação dessas tendências, algumas hipóteses foram levantadas. A primeira explicação está relacionada à não aleatoriedade durante a seleção de locos para as espécies focais. Durante a caracterização dos locos, busca-se escolher justamente aqueles com alelos maiores e maior polimorfismo, o que demonstra que o esforço amostral na detecção do polimorfismo é maior na espécie focal (Chambers \& MacAvoy, 2000). A segunda explicação é a distância filogenética entre as espécies. Geralmente, o sucesso na amplificação heteróloga é inversamente proporcional ao tempo de separação filogenética das duas espécies. O acúmulo de mutações nas regiões que flanqueiam os microssatélites na espécie não-focal pode resultar tanto na falha de amplificação heterológa como na ausência de polimorfismo, nesse caso, decorrente da fixação de alelos nulos (Chambers \& MacAvoy, 2000). É denominado alelo nulo a falha de amplificação de um dos alelos devido à ocorrência de mutação na seqüência iniciadora do loco. Alelos nulos têm sido encontrados em mais de $25 \%$ dos locos de microssatélites, chegando a atingir freqüências superiores a 15\% (Jarne \& Lagoda, 1996). A ocorrência de alelos nulos foi apontada como a principal responsável pela detecção errônea de quantidade maior de genótipos homozigóticos em populações avaliadas por locos microssatélites (Aldrich et al., 1998; White et al., 1999).

Em um estudo com populações de espécies arbóreas, Aldrich et al. (1998) constataram que o déficit de genótipos heterozigóticos era tipicamente maior nos locos de microssatélites com maior polimorfismo. A maior taxa de mutação nesses locos resulta tanto em maior polimorfismo, como na maior freqüência de alelos nulos. Observou-se no presente estudo que o loco que apresentou o maior número de alelos (CA158) também mostrou desvios mais expressivos das proporções esperadas pelo EHW. Além da ocorrência de alelos nulos, a dificuldade na distinção de alelos que são muito próximos em tamanho e a confusão entre um alelo e seu "sttuter" podem resultar em erro na interpretação dos genótipos microssatélites (Aldrich et al., 1998). Conclusões a respeito da diversidade genética e da endogamia em populações estudadas com iniciadores desenvolvidos para outras espécies devem ser tomadas com cautela, assim como a comparação entre espécies e com estudos desenvolvidos com outros marcadores. 
Tanto o índice de fixação $(\hat{f})$ como o teste de EHW medem a proporção de genótipos heterozigóticos em relação ao esperado pelas proporções de HardyWeinberg. Estimativas elevadas de índice de fixação geralmente são interpretadas como decorrentes da endogamia na população. Porém, como já discutido anteriormente, o déficit de genótipos heterozigóticos pode ser devido à presença de alelos nulos e a erros na interpretação dos genótipos. O estudo de determinação do sistema de reprodução de $S$. lycocarpum demonstrou que a espécie reproduz-se predominantemente por cruzamento e que as autofecundações e os cruzamentos entre parentes não ocorrem com freqüência significativa. Logo, é possível concluir que a ocorrência de alelos nulos teve maior contribuição na estimativa do $\hat{f}$ do que a endogamia.

\subsection{Diversidade genética intrapopulacional}

A hipótese de diversidade genética elevada nas populações naturais de $S$. lycocarpum (item 1.2 a) foi corroborada pelas estimativas de diversidade genética com marcadores cloroplastidiais. Em média, foram detectadas 28,4 $( \pm 2,67)$ haplótipos nas populações e a diversidade haplotípica média foi $0,947 \quad( \pm 0,012)$. Os locos microssatélites nucleares, por outro lado, não puderam ser considerados para a confirmação dessa hipótese, devido aos problemas decorrentes da amplificação heteróloga citados anteriormente, e à variação entre locos, que resulta em estimativas pouco consistentes.

Diferenças significativas nos níveis de diversidade genética entre as populações naturais e as plantas da margem da estrada não foram observadas, diferentemente do esperado pela hipótese proposta no início do trabalho (item 1.2 b). Acredita-se que a colonização das áreas antrópicas por $S$. lycocarpum ocorra predominantemente por sementes, e que essas são trazidas de diferentes populações pelos agentes dispersores, quando defecam nas estradas. Logo, esperar-se-ia maior diversidade genética nos indivíduos situados na margem da estrada em relação às populações naturais. Constatou-se apenas uma tendência de menor diversidade 
genética na população $D$, embora a diferença não tenha sido significativa em decorrência dos amplos erros-padrão.

Nas populações em que o índice de fixação foi nulo (B, C e D), observou-se que os indivíduos espacialmente mais próximos (separados por até $50 \mathrm{~m}$ ) eram geneticamente semelhantes. A estruturação espacial está associada principalmente às características do sistema de reprodução das espécies (Loveless \& Hamrick, 1984), que resultam em dispersão de genes restrita, tanto em decorrência da pequena capacidade de migração de pólen, como pela dispersão de sementes a curtas distâncias (Levin, 1981; Loveless \& Hamrick, 1984). A curva de distribuição do movimento do pólen é geralmente leptocúrtica, com a maior quantidade de pólen sendo depositada a poucos metros da fonte (Slatkin, 1985).

Em S. lycocarpum, a ocorrência de autocorrelação espacial dos genótipos dentro das populações era esperada (item $1.2 \mathrm{c}$ ). A distribuição espacial dos indivíduos de $S$. lycocarpum nas populações não é uniforme, ou seja, as plantas formam agrupamentos de poucos indivíduos, que podem ser tanto resultantes da dispersão de sementes restrita, em que as sementes germinam próximas à árvore-mãe, como da propagação vegetativa. 0 comportamento de forrageio do principal agente polinizador (Xylocopa) pode favorecer o cruzamento entre os indivíduos espacialmente próximos, uma vez que a polinização é vibrátil. A vibração da abelha na flor provoca uma nuvem de pólen e a abelha visita todas as flores abertas próximas antes de voar para arbustos mais distantes (Oliveira-Filho \& Oliveira, 1988).

O aparente contra-senso entre presença de autocorrelação espacial e ausência de endogamia nas populações pode ser decorrente tanto da depressão por endogamia como de mecanismos de auto-incompatibilidade. Em S. Iycocarpum, experimentos de germinação de grãos de pólen no estigma mostraram que o sucesso na formação de frutos só foi verificado a partir de flores hermafroditas e após polinização cruzada (Oliveira-Filho \& Oliveira, 1988). O estudo do sistema de reprodução de $S$. lycocarpum mostrou que a taxa de cruzamento foi elevada, corroborando a hipótese considerada no início deste estudo de que a espécie é predominantemente alógama (item $1.2 \mathrm{~d}$ ). 0 cruzamento entre parentes não foi comum e a correlação de paternidade foi muito reduzida em comparação ao que tem sido observado em espécies arbóreas de cerrado 
e de florestas. A caracterização do sistema de reprodução de $S$. lycocarpum demonstrou o que já foi apresentado por Slatkin (1985): mesmo quando a dispersão de pólen aparenta ser altamente localizada, fluxo gênico efetivo (que resulta em sementes viáveis) pode estar ocorrendo em distâncias maiores. Essa constatação mostra que o fluxo gênico mediado por pólen em $S$. lycocarpum pode ser menos restrito do que se imaginava (hipótese f - item 1.2) a partir das informações a respeito dos polinizadores. A correlação de paternidade baixa $\left(r_{p}\right)$ mostra que os frutos são compostos por sementes de múltiplas origens, ou seja, os óvulos são fecundados por pólen de diferentes pais. Em um estudo com quatro populações de Caryocar brasiliense, uma espécie do cerrado polinizada por morcegos, Collevatti et al. (2001a) obtiveram estimativas de correlação de paternidade $\left(\hat{r}_{p} \cong 0,20\right)$ superiores ao obtido para $S$. lycocarpum.

A biologia floral da espécie é outro fator que contribui para o grande número de doadores de pólen nos cruzamentos. $S$. lycocarpum é uma espécie andromonóica, sendo que na mesma árvore há flores hermafroditas e funcionalmente masculinas (com estigma atrofiado). A principal conseqüência da condição andromonóica é a maior proporção pólen/óvulos. Ambos os tipos de flores, que permanecem abertas por cerca de 24 horas, produzem quantidade elevada de pólen viável (Oliveira-Filho \& Oliveira, 1988). Além disso, ainda que poucas flores estejam abertas ao mesmo tempo em cada indivíduo, em toda a população muitas flores abrem-se diariamente. Moura (2004) detectou em uma população em Morrinhos (GO) que cerca de 75\% das plantas apresentavam flores abertas e variação de 4,47 a 8,23 flores abertas por planta.

Assim como o fluxo gênico mediado por pólen, a dispersão de sementes é produto do hábito de forrageamento de animais dispersores. A constatação de que as populações naturais de $S$. lycocarpum foram fundadas por múltiplas linhagens maternas e a eficiência na colonização de novos ambientes mostram que $S$. lycocarpum apresenta mecanismos eficientes de dispersão de sementes a longas distâncias. Entretanto, a autocorrelação espacial indica que plântulas podem estar regenerando próximas à arvore-mãe. Os frutos de $S$. lycocarpum completam o amadurecimento após caírem ao chão. Aqueles que não são consumidos pela fauna permanecem sob a copa 
da árvore. Em geral, as sementes de frutos não dispersos tornam-se inviáveis, seja devido à contaminação por fungos (Pinto, 1998) ou à predação por besouros e roedores (Rodrigues, 2002). No entanto, sabe-se que as formigas saúvas atuam significativamente na dispersão secundária. Elas carregam as sementes tanto de frutos caídos no chão, como de fezes de animais e as carregam para o sauveiro. Após a retirada da polpa das sementes, cerca de $40 \%$ são descartadas no refugo do sauveiro (Courtenay, 1994). A capacidade de carregamento das formigas, todavia, é restrita, uma vez que a distância de migração é de apenas dois a cinco metros (Pinto, 1998). Como conseqüência, indivíduos espacialmente mais próximos na população podem ser filhos da mesma mãe.

É muito comum observar indivíduos de $S$. lycocarpum sobre sauveiros, tanto por causa do comportamento das saúvas como pelo fato do lobo-guará - principal consumidor do fruto e agente dispersor das sementes - preferir defecar em locais altos como sauveiros e cupinzeiros. A associação entre $S$. lycocarpum e formigas saúvas é tão marcante em algumas regiões que diversos estudos abordando especificamente essa associação já foram conduzidos (Courtenay, 1994; Martins \& Motta-Junior, 2000; Pinto, 1998).

O gado também se alimenta freqüentemente de frutos de $S$. lycocarpum e dispersa suas sementes. Devido à proximidade das populações coletadas a pastagens e ao livre trânsito desses animais, acredita-se que o gado contribua significativamente para a dispersão de sementes nas populações estudadas. Como o trânsito desses animais é restrito à área do pasto, estes dispersam as sementes apenas dentro das populações e nos pastos adjacentes e podem estar contribuindo para a ocorrência correlação espacial de genótipos. Vestígio de trânsito atual de gado foi observado na população B.

A ocorrência de propagação vegetativa por raízes e rizomas também deve ser considerada para a espécie. Esse processo já foi detectado em outras espécies do Cerrado (Rizzini \& Heringer, 1962), e pode ser considerado uma estratégia de regeneração após a ocorrência de fogo, fenômeno muito comum nesse bioma (Hoffman, 1998). A propagação vegetativa por raiz em $S$. lycocarpum não foi avaliada neste estudo e também não se encontrou trabalho publicado sobre o assunto. Todavia, 
sabe-se que a suas raízes são profundas (Grotta ${ }^{3}$ citado por Elias et al., 2003) e que a brotação após corte raso é freqüente (observação pessoal). Dessa forma, uma planta com parte aérea pequena pode possuir um sistema radicular bem desenvolvido e indivíduos espacialmente próximos podem se constituir em rebrotas de uma mesma raiz. Indivíduos de pequeno porte (com cerca de $30 \mathrm{~cm}$ de altura), apresentando flores e frutos são comumente observados em ambientes com vegetação de cerrado alterado (observação pessoal), sugerindo propagação vegetativa.

O agrupamento dos pares de indivíduos que compartilham genótipos nucleares e cloroplastidiais idênticos (grupo ID) mostrou que uma porcentagem muita pequena das plantas $(0,17$ a 1,23\%) podem ser consideradas clones. Essas porcentagens indicam que a propagação vegetativa não é tão freqüente em $S$. lycocarpum como se supunha pela hipótese c (item 1.2). No entanto, embora a porcentagem de indivíduos clones tenha sido baixa em todas as populações, a variação entre as populações foi elevada. A porcentagem de clones foi cerca de sete vezes maior na população $D$, em relação ao observado nas demais populações. Essa variação entre as populações indica o potencial da espécie de se propagar vegetativamente. Vale ressaltar que o agrupamento dos pares de indivíduos idênticos foi realizado com a utilização de número pequeno de locos microssatélites, e estes eram pouco polimórficos. Conclusões mais consistentes da importância da propagação vegetativa em populações de $S$. lycocarpum serão possíveis quando for utilizado maior número de locos.

Estudos teóricos e simulações (Epperson, 1990; Epperson, 1995; Wright, 1943) demonstram que, sob condições de fluxo gênico restrito, as populações desenvolvem estruturação espacial de genótipos, com correlação positiva que declina com a distância. No entanto, a autocorrelação espacial em populações naturais geralmente é fraca e/ou inconsistente (Heywood, 1991; Smouse \& Peakall, 1999). Constatou-se na população D uma forte autocorrelação espacial na primeira classe de distância $(\hat{r}=0,25)$, com valor semelhante ao parentesco esperado para meios-irmãos.

\footnotetext{
${ }^{3}$ Grotta, A.S. Contribuição à sistemática de $S$. Iycocarpum St. Hil. Tese de Livre Docência. Universidade de São Paulo, São Paulo. 1964.
} 
A primeira explicação para esse resultado é que o fluxo gênico pode ser mais restrito nessa população do que nas demais. A tendência de menor diversidade genética com os marcadores nucleares, associada ao menor número de haplótipos, indicam que essa população pode ter sido fundada por menor variedade de sementes (linhagens maternas). Provavelmente, o trânsito de fauna consumidora de frutos é menos freqüente nessa população, resultando tanto na menor colonização por sementes trazidas de outras áreas, como na restrição espacial da dispersão das sementes produzidas na população.

Uma outra hipótese é que a população $D$ apresenta origem mais recente que as outras populações. A presença de locos nucleares em desequilíbrio genotípico e de pares de locos cloroplastidiais que não mostram associação são indícios de que a população pode ser nova e talvez não tenha atingido o equilíbrio (Hartl \& Clark, 1997). Essa população pode ter sido fundada há poucas gerações ou pode ter passado por alguma alteração, tais como desmatamento ou queimada, resultando no efeito de gargalo genético e perda de diversidade genética. Informações de moradores locais indicam que, pelo menos nos últimos 70 anos, a área em que foi coletada a população D não sofreu desmatamento. Simulações sobre o efeito da restrição de fluxo gênico mostram que a autocorrelação espacial é alta em populações recentes, mas que decresce a uma taxa constante nas gerações subseqüentes (Epperson, 1990).

Nas populações naturais A, B e C e nas plantas na margem da estrada, a coancestralidade foi praticamente nula, inclusive nos pares de indivíduos que compartilham genótipos cloroplastidiais idênticos (grupo LM). Contrariamente, a população $D$ apresentou estimativa de coancestralidade nesse grupo semelhante ao esperado para meios-irmãos $(\hat{r}=0,18)$. Em uma situação hipotética, em populações sob panmixia, ausência de endogamia e sem sobreposição de gerações, o valor da coancestralidade cai à metade em cada geração. Enquanto a coancestralidade entre mãe e filha é $1 / 4=0,250$ e entre meias-irmãs é $1 / 8=0,125$, a coancestralidade esperada entre plantas com o mesmo ancestral materno, mas separadas por três gerações é de $1 / 32=0,0312$ e, se estiverem separadas por quatro gerações, a coancestralidade é $1 / 64=0,0156$. $O$ valor da coancestralidade observado na população 
D pode indicar que não há sobreposição de gerações, corroborando a hipótese de colonização recente. Acredita-se que a maior proporção de indivíduos pertencentes a uma mesma geração e a restrição do fluxo gênico por sementes nessa população sejam dois fatores que, atuando em conjunto, contribuíram para a coancestralidade e para a forte autocorrelação espacial na população D. Nesse caso, há muitos agrupamentos de indivíduos observados na população que, provavelmente, são irmãos maternos e, por isso, a coancestralidade entre elas é próxima de 0,125. Essa hipótese é corroborada pela observação a campo de que há muitos agrupamentos de $S$. lycocarpum formados por uma planta reprodutiva de grande porte e com muitas plantas menores ao redor.

O terceiro fator que pode ter ocorrido concomitantemente aos já citados é a diferença de sucesso reprodutivo entre as plantas. Um número pequeno de mães contribuiu (e continua contribuindo) com maior número de descendentes na população. Essa hipótese é corroborada pelo menor número de haplótipos observados nessa população.

\subsection{Estrutura genética}

A divergência genética entre populações e os baixos níveis de endogamia são condizentes com as características ecológicas da espécie. A ocorrência de indivíduos de S. lycocarpum nas margens das estradas e a regeneração em pastos são fatores que atenuam os efeitos da deriva genética e favorecem o fluxo gênico. A divergência genética entre as populações geograficamente mais próximas ( $A, B$ e $C$ ) não diferiu estatisticamente de zero, o que indica que, antes da vegetação nativa da região ser fragmentada, essas três populações constituíam uma única população panmítica. Devido à descontinuidade atual de vegetação entre as mesmas, pode-se considerá-las atualmente como subpopulações.

A diferenciação genética entre populações estimada com marcadores cloroplastidiais $\left(\hat{\theta}_{p C}=0,042\right)$ foi ligeiramente menor que a obtida para marcadores nucleares $\left(\hat{\theta}_{p}=0,054\right)$. A baixa divergência entre as populações confirma a hipótese de que a maior proporção da diversidade genética encontra-se dentro de populações (item 
1.2 e). Em um estudo recente de revisão, Petit et al. (2005) observaram que de 93 espécies angiospermas e gimnospermas, apenas em três a diferenciação genética com marcadores de herança materna foi inferior à diferenciação medida com marcadores nucleares. De acordo com os mesmos autores, o valor médio da diferenciação genética obtida com marcadores cloroplastidiais foi de 0,637 $( \pm 0,002)$, em 124 espécies de angiospermas, enquanto que, para marcadores nucleares, foi de 0,184 $( \pm 0,002)$, em 77 espécies de angiospermas. A comparação desses resultados com o presente estudo deve ser cautelosa. Isso porque os resultados mostrados na revisão de Petit et al. (2005) basearam-se em estudos realizados em maior escala geográfica, englobando, na maioria das vezes, a área de distribuição da espécie estudada e, devido às maiores distâncias geográficas, são esperados valores mais elevados de divergência genética.

Considerando-se a diferença no tamanho efetivo de genomas haplóides e diplóides, esperar-se-ia maior diferenciação populacional para marcadores cloroplastidiais do que nucleares. Como o genoma cloroplastidial é haplóide, herdado uniparentalmente e sem recombinação, assume-se que o tamanho efetivo desse genoma é menor e, portanto, mais sensível aos efeitos da deriva genética do que o genoma nuclear (Birky et al., 1989). Como conseqüência, o nível de diferenciação populacional no equilíbrio é maior para marcadores cloroplastidiais (Petit et al., 1993).

Além do tamanho efetivo do genoma, a diferenciação populacional obtida com marcadores nucleares e cloroplastidiais depende também das taxas de migração de pólen e sementes, da taxa de cruzamento e do modo de herança das organelas (Hamilton \& Miller, 2002; Petit et al., 1993). Com a ocorrência de autofecundação, os genes nucleares dispersam apenas via sementes, logo, em espécies com sistema misto de reprodução, a dispersão média de genes nucleares via pólen é reduzida por um fator igual à taxa de autofecundação (Hamilton \& Miller, 2002).

A ocorrência de transmissão paterna do cloroplasto tem um efeito significativo no nível de diferenciação populacional medida com marcadores cloroplastidiais, uma vez que possibilita a dispersão desses genes via pólen. Mesmo uma reduzida taxa de transmissão paterna do cloroplasto resulta em queda significativa na diferenciação populacional obtida com esses marcadores. A menor diferenciação é ainda mais 
acentuada se a taxa de migração de pólen é muito superior a de sementes (Petit et al., 1993).

Como em S. lycocarpum a ocorrência de autofecundação e a transmissão paterna do cloroplasto são mínimas, pode-se inferir que, tanto a reduzida divergência entre populações estimada com marcadores cloroplastidiais, quanto a semelhança com a divergência obtida com marcadores nucleares devem-se à contribuição significativa da migração de sementes no fluxo gênico total.

A contribuição significativa da dispersão de sementes no fluxo gênico total, detectada no presente estudo, é semelhante ao observado para outras espécies que combinam polinização por insetos e dispersão de sementes por endozoocoria e apresentam uma dinâmica de extinção/recolonização (Raspe et al., 2000). OddouMuratorio et al. (2001) discutem que esta combinação de características de história de vida resulta em níveis menores de diferenciação entre populações, especialmente para marcadores de herança materna, devido à ocorrência de eventos de colonização por múltiplas fundações.

Acredita-se que a contribuição do fluxo gênico por sementes em $S$. lycocarpum é ainda maior que o estimado $\left(m_{p} / m_{s}=1,22\right)$. Isso porque o método proposto por Ennos (1994) pressupõe que o tamanho efetivo de plantas masculinas e femininas na população é semelhante. Embora S. Iycocarpum seja hermafrodita, devido à andromonoicia, o número de flores masculinas é superior ao de femininas. Logo, funcionalmente, o tamanho efetivo masculino é maior que o feminino. Em um estudo realizado com a espécie androdióica, Sorbus terminalis, Oddou-Muratorio et al. (2001) obtiveram razão de fluxo gênico $m_{p} / m_{s}=2,21$. Contudo, após quantificarem a proporção de plantas masculinas e hermafroditas nas populações, os autores reestimaram a razão de fluxo gênico com uma correção dos tamanhos efetivos e obtiveram um valor de 1,18 .

A proporção de flores funcionalmente masculinas e hermafroditas em $S$. lycocarpum é muito variável, tanto entre inflorescências de uma mesma planta, quanto entre diferentes plantas da população. Em um estudo realizado em Minas Gerais, a proporção de flores masculinas variou entre 20 a 75\% (Oliveira-Filho \& Oliveira, 1988). 
Como a variação na proporção de flores masculinas foi considerável, e os autores não consideraram a variação temporal (realizaram apenas uma medição), torna-se difícil calcular uma correção de tamanho efetivo para $S$. Iycocarpum.

A eficiência da dispersão de sementes de $S$. Iycocarpum mostrou-se mais significativa a longas distâncias, corroborando a hipótese inicial desse trabalho (item 1.2 f). Como pôde ser verificado pela comparação do fluxo de sementes entre pares de populações, o fluxo gênico via semente assume maior contribuição relativa quando são comparadas as populações mais distantes geograficamente. A dispersão de sementes é por endozoocoria e os frutos carnosos são procurados por diversos animais do cerrado, especialmente mamíferos como o cachorro-do-mato (Dusicyon thous), a raposa-docampo (Lycalopex vetulus), o lobo-guará (Chrysocyon brachyurus) e a anta (Tapirus terrestris). A observação de que as populações naturais e os ambientes alterados (margem da estrada) foram colonizados por sementes de diversas linhagens demonstra a eficiência dos agentes dispersores na efetivação do fluxo gênico por sementes.

$O$ fato de os principais mamíferos dispersores de sementes de $S$. lycocarpum apresentarem áreas de vida variáveis indica que os mesmos contribuem para a dispersão de sementes em escalas geográficas distintas. A raposa-do-campo, por exemplo, apresenta área de vida entre dois e quatro $\mathrm{km}^{2}$ e o cachorro-do-mato apresenta área de vida entre 0,5 e $22 \mathrm{~km}^{2}$ (Rodrigues ${ }^{4}, 2002$ ). A capacidade de trânsito desses canídeos é mais restrita que a do lobo-guará que, por apresentar hábitos cursoriais e ampla área de vida, que varia de 30 (Dietz, 1984) a $105 \mathrm{~km}^{2}$ (Rodrigues, 2002), pode ser considerado o principal dispersor de sementes de $S$. lycocarpum a longas distâncias. A anta também pode ser considerada um agente dispersor a longas distâncias por possuir áreas de vida de mais de $100 \mathrm{Km}^{2}$. Entretanto, essas nem sempre defecam em ambientes apropriados para a germinação da semente ${ }^{5}$ de $S$. lycocarpum. Considerando o local de deposição das sementes, os três canídeos supracitados contribuem para a colonização de novos ambientes, uma vez que defecam em locais abertos e iluminados como sauveiros e margens de estradas, em que a planta estabelece-se plenamente.

\footnotetext{
${ }^{4} \mathrm{O}$ autor cita diversos trabalhos que estimaram a área de vida desses animais e apresenta os valores máximos e mínimos de área de vida

5 João Dagoberto dos Santos (ESALQ-USP). Comunicação pessoal
} 
Diversas razões fazem com que o lobo-guará seja considerado o principal dispersor de sementes de $S$. lycocarpum. O lobo consome o fruto o ano inteiro, mesmo quando este é mais escasso (Dietz, 1984; Motta-Junior et al. 1996), ingere grande quantidade de frutos em cada refeição (Rodrigues, 2002), a quantidade de sementes danificadas na mastigação é pequena (Motta-Junior \& Martins, 2002), ele defeca sementes viáveis, com elevada taxa de germinação (Courtenay, 1994; Lombardi \& Motta-Junior, 2003; Motta-Junior \& Martins, 2002; Pinto, 1998; Rodrigues, 2002, Santos et al., 2003) e defeca em ambientes em que a planta ocorre com freqüência, como sauveiros e margens de estrada (Dietz, 1984; Santos et al., 2003).

Os testes de maternidade com os indivíduos de $S$. lycocarpum que colonizaram a margem da estrada mostraram que, embora as distâncias de migração tenham sido variáveis (770 metros a 42,65km), a distância média de migração da semente foi de cerca de 20,26 km. Foram observadas, também, distâncias de dispersão de sementes superiores a $40 \mathrm{~km}$. Todavia, devido à baixa consistência dos locos utilizados nas inferências de maternidade e à presença de muitos indivíduos de $S$. lycocarpum adjacentes às populações naturais que não foram amostrados, é um pouco precipitado afirmar que o fluxo gênico via sementes alcance essas distâncias. Embora o lobo-guará, principal dispersor de sementes de $S$. lycocarpum a longas distâncias, apresente áreas de vida superiores a $100 \mathrm{~km}^{2}$, a capacidade de caminhada é de cerca de $20 \mathrm{~km}$ por noite (Carvalho, 1976). De acordo com Barboza et al. (1994), o tempo médio de passagem do alimento pelo sistema digestório é de aproximadamente 20 a 30 minutos. Todavia, o tempo de digestão pode variar de acordo com o tipo de alimento que é ingerido. Wahaj et al. (1998) afirmam que os glicoalcalóides presentes em frutos maduros de solanáceas têm um efeito laxativo e podem acelerar o tempo passado pela semente no sistema digestório dos frugívoros. Vale destacar que a distância média de migração de sementes $(20,26 \mathrm{~km})$ foi similar à distância que o loboguará percorre em uma noite (20 km, de acordo com Carvalho, 1976).

A contribuição relativa da migração de pólen e sementes foi dependente da escala de estudo. Como $S$. lycocarpum é uma espécie generalista, em que a dispersão de sementes é realizada por animais com diferentes hábitos de forrageamento e capacidades de movimentação distintas, pode-se verificar que diversos mecanismos 
contribuem para o modo predominante de fluxo gênico em cada escala espacial. Em escala micro-espacial dentro das populações, uma parte significativa da dispersão de sementes é restrita e a principal contribuição é da dispersão por formigas, gado e pequenos animais de circulação limitada. Em escala intermediária (dentro das populações e entre populações próximas), a polinização tem contribuição significativa no fluxo gênico total. Em escala geográfica de intermediária a ampla a contribuição da dispersão de sementes por animais assume uma maior importância relativa, permitindo a colonização de novos ambientes.

\subsection{Indicadores para conservação genética}

A ocorrência de $S$. lycocarpum em ambientes alterados, em densidade cerca de 10 vezes maior à observada em vegetação preservada (Courtenay, 1994), poderia demonstrar que a fragmentação da vegetação natural do cerrado ainda não ameaça a sobrevivência da espécie e esteja até a beneficiando. Isso porque, atualmente, a presença expressiva de indivíduos da espécie em ambientes alterados resulta em uma expansão do tamanho efetivo das populações. Porém, no que se refere à conservação da espécie em longo prazo, duas observações devem ser consideradas.

Em primeiro lugar, as áreas com espécies nativas - tanto em cerrado preservado como em ambientes alterados - têm sido convertidas em monoculturas em uma taxa de, aproximadamente, 1,5\% ao ano (Machado et al., 2004). O asfaltamento de rodovias e a supressão da vegetação nas margens também devem ser considerados. O fato de apenas cerca de 1,5\% da vegetação do cerrado estar protegida em Unidades de Conservação (Ratter et al., 1997) torna as espécies do cerrado ainda mais vulneráveis. Considerando apenas a área de abrangência do presente estudo, o número de populações necessárias para reter um tamanho efetivo de pelo menos 500 indivíduos é de 54. Prudentemente, devido às razões supracitadas, essa estimativa foi calculada sem considerar as populações antrópicas.

Em segundo lugar, a conservação de $S$. lycocarpum não deve ser considerada

de maneira isolada, e o que deve ser planejado é a conservação do bioma que a espécie faz parte. Isso porque a espécie é polinizada e dispersa por animais, logo, a 
variabilidade genética e a maneira como esta está estruturada entre em dentro de populações é conseqüência das interações com os animais. As abelhas polinizadoras podem ser muito afetadas pelos agrotóxicos pulverizados nas plantações adjacentes aos fragmentos de cerrado, resultando em uma diminuição na produção de frutos. Os mamíferos dispersores de sementes também têm sido muito ameaçados pela fragmentação, em especial devido à ampla área de vida que apresentam. $S$. lycocarpum constitui importante fonte de alimento para diversos animais do Cerrado, especialmente durante a estação seca quando a produção dos outros frutos é escassa.

S. Iycocarpum apresenta amplo potencial para plantio em planos de restauração. Apresenta rápida germinação e emergência (Vidal, 2000), as sementes germinam a pleno sol, a planta cresce rápido e se adapta bem a situações de escassez hídrica (Chaves-Filho \& Stacciarini-Seraphin, 2001; Elias et al., 2003; Vidal, 2000). Adicionalmente, produz frutos carnosos que atraem a fauna para as áreas restauradas. $\mathrm{Na}$ coleta de sementes a campo para produção de mudas, deve-se coletar igual número de sementes de 150 a 200 matrizes para reter o tamanho efetivo de 500 indivíduos, sendo que estas devem estar distantes umas das outras mais de $50 \mathrm{~m}$. Como a espécie está distribuída por praticamente toda a abrangência do Cerrado, deve-se ainda planejar a coleta de modo a amostrar o maior número possível de populações em uma área extensa.

Esse estudo possibilitou o conhecimento do sistema de reprodução e da estrutura genética de $S$. lycocarpum e buscou uma associação com a biologia da reprodução da espécie, atentando, em especial, para os agentes de fluxo gênico. Os resultados mostraram que a estratégia de uso de marcadores de cloroplasto para quantificação das parcelas que compõem o fluxo gênico total é útil na definição das estratégias de conservação in situ, especialmente para $S$. lycocarpum em que as sementes são dispersas por uma variedade de animais. É possível planejar a distância máxima entre os fragmentos de cerrado e o estabelecimento de corredores para trânsito de fauna. No caso de $S$. lycocarpum, por exemplo, o fluxo gênico mediado por sementes ocorre em uma maior freqüência até uma distância de cerca de $20 \mathrm{~km}$. Se a presença de indivíduos nas margens das estradas não for considerada, a distância de $20 \mathrm{~km}$ seria a distância máxima separando fragmentos de vegetação nativa. Além disso, 
as margens das estradas de terra que interligam as populações naturais podem estar atuando como corredores de fluxo gênico.

Os resultados de diversidade genética na margem das estradas mostraram também que, embora a densidade populacional de $S$. lycocarpum se altere em condições antrópicas, não foram observados efeitos negativos na diversidade genética das populações nessas áreas. Esses resultados mostram que $S$. lycocarpum pode ser considerada uma espécie indicadora da ocorrência de intervenção humana, uma vez que a densidade populacional altera-se com a intervenção, mas não é aconselhável que seja selecionada como uma espécie indicadora dos efeitos genéticos negativos resultantes da fragmentação. Se o interesse for a escolha de uma espécie que sirva como modelo, o ideal é selecionar uma espécie geneticamente sensível aos efeitos da intervenção humana.

Diversos estudos ainda podem ser conduzidos para o entendimento mais detalhado da biologia da espécie e das possíveis alterações ecológicas e genéticas das populações. Algumas sugestões de estudos futuros são: (1) avaliar a produção de flores hermafroditas e funcionalmente masculinas, buscando estimar os tamanhos efetivos masculino e feminino nas populações e se há variação temporal; (2) estudar estrutura genética micro-espacial em populações antrópicas (pastos) e buscar compreender o processo de fundação dessas populações; (3) avaliar o fluxo gênico atual entre as populações naturais e antrópicas; (4) avaliar a estrutura genética em maior número de populações, buscando abranger a área de ocorrência da espécie e realizar estudos de filogeografia; (5) estudar o tempo de vida da espécie e o tempo até o florescimento; (6) estudar a dinâmica das populações para avaliar se as mesmas estão estruturadas como uma metapopulação; (7) avaliar a campo a ocorrência de regeneração por meio de raiz. 


\section{CONCLUSÕES}

O presente trabalho permitiu concluir que:

1. O estudo comparativo de marcadores moleculares nucleares e cloroplastidiais é eficiente para a quantificação das parcelas que compõem o fluxo gênico total;

2. A comparação de estudos realizados com amplificação heterológa de locos microssatélites deve ser cautelosa, devido ao menor polimorfismo;

3. Solanum lycocarpum reproduz-se predominantemente por cruzamentos e o número de árvores que participam como doadoras de pólen nos cruzamentos foi superior a dez;

4. As populações naturais e as áreas antrópicas foram fundadas por sementes de múltiplas origens;

5. A espécie apresenta estrutura espacial dos genótipos com manchas de até $50 \mathrm{~m}$ de raio, devido à dispersão de sementes espacialmente restrita;

6. A regeneração de novos indivíduos por meio de raiz ocorre, mas não é comum em populações naturais;

7. A dispersão de sementes em longas distâncias é efetiva e regular até a distância de $20 \mathrm{~km}$ e possibilita a colonização de novas áreas;

8. As populações antrópicas contribuem para o aumento no tamanho efetivo das populações. 


\section{REFERÊNCIAS BIBLIOGRÁFICAS}

AB'SABER, A.N. Os domínios morfoclimáticos da América do Sul. Primeira Aproximação. Geomorfologia, v.52, p.1-21, 1977.

ADAMS, J. Reproduction. In: GAMLIM, L.; VINES, G. The evolution of life. New York: Oxford University Press, 1991. cap.27, p.235-248.

AIZEN, M.A.; FEINSINGER, P. Forest fragmentation, pollination, and plant reproduction in a Chaco dry forest, Argentina. Ecology, v.75, n.2, p.330-351, 1994.

ALDRICH, P.R.; HAMRICK, J.L.; CHAVARRIAGE, P.; KOCHERT, G. Microsatellite analysis of demographic genetic structure in fragmented populations of the tropical tree Symphonia globulifera. Molecular Ecology, v.7, n.8, p.933-944, 1998.

ARAÚJO, M.R.; SOUZA, O.C. de. Fragmentação florestal e a degradação das terras.

In: COSTA, R.B. da (Org.) Fragmentação florestal e alternativas de desenvolvimento rural na região Centro-Oeste. Campo Grande: UCDB, 2003. cap.5, p.113-138.

ARAÚjO, T.C.C. Estrutura da variabilidade genética e estrutura populacional de Caryocar brasiliense Camb. no estado de Goiás utilizando marcadores RAPD. Goiânia, 2003. 87p. Dissertação (Mestrado) - Instituto de Ciências Biológicas, Universidade de Goiás.

BARBOZA, P.S.; ALLEN, M.E.; RODDEN, M.; POJETA, K. Feed intake and digestion in the maned wolf (Chrysocyon brachyurus): consequences for dietary management. Zoo Biology, v.13, p.375-381, 1994.

BEZERRA, E.L. DE S.; MACHADO, I.C. Biologia floral e sistema de polinização de Solanum stramonifolium Jacq. (Solanaceae), em remanescente de Mata Atlântica, Pernanbuco. Acta Botânica Brasílica, v.17, n.2, p.247-257, 2003. 
BIRKY, C.W.; FUERST, P.; MARUYAMA, T. Organelle gene diversity under migration, mutation and drift: equilibrium expectations, approach to equilibrium, effects of heteroplasmic cells, and comparison to nuclear genes. Genetics, v.121, n.3, p.613627, 1989.

BOSHIER, D.H. Mating systems. In: YOUNG, A.; BOSHIER, D.; BOYLE, T. (Eds.)

Forest conservation genetics: principles and practice. Collingwood: CSIRO Publishing, 2000. cap.5, p.63-79.

BOSHIER, D.H.; CHASE, M.R.; BAWA, K.S. Population genetics of Cordia alliodora (Boraginaceae), a neotropical tree. 2. mating system. American Journal of Botany, v.82, n.4, p.476-483, 1995.

BOYLE, T.J. Criteria and indicators for the conservation of genetic diversity. In: YOUNG, A.; BOSHIER, D.; BOYLE, T. (Eds.) Forest conservation genetics: principles and practice. Collingwood: CSIRO Publishing, 2000. cap.18, p.239-251.

BRIDGEWATER, S.; RATTER, J.A.; RIBEIRO, J.F. Biogeographic patterns, $\beta$-diversity and dominance in the cerrado biome of Brazil. Biodiversity and Conservation, v.13, n.12, p.2295-2318, 2004.

BRONDANI, R.P.V.; BRONDANI, C.; TARCHINI, R.; GRATTAPAGLIA, D. Development, characterization and mapping of microsatellite loci, in the genus Eucaliptus. Australian Journal of Botany, v.44, p.331-341, 1998.

BUCHMANN, S.L. Buzz pollination in Angiosperms. In: C.E. JONES; R.J. LITTLE (Eds.). Handbook of experimental pollination biology. New York: Van Nostrand Reinhold, $1983.588 p$.

BUENO, A.A.; MOTTA-JUNIOR, J.C. Food habits of two syntopic canids, the maned wolf (Chrysocyon brachyurus) and the crab-eating fox (Cerdocyon thous) in southeastern Brazil. Revista Chilena de História Natural, v.77, n.1, p.5-14, 2004.

BURCZYK, J.; DiFAZIO, S.P.; ADAMS, W.T. Gene flow in forest trees: how far do genes really travel? Forest Genetics, v.11, n.2-3, p.1-14, 2004.

CAIN, M.L.; MILLIGAN, B.G.; STRAND, A.E. Long-distance seed dispersal in plant populations. American Journal of Botany, v.87, n.9, p.1217-1227, 2000. 
CARVALHO, C. T. Aspectos faunísticos do cerrado - o lobo-guará (Mammalia, Canidae). Boletim Técnico do Instituto Florestal de São Paulo v.21, p.1-18, 1976.

CASTRO, A.A.J.F.; MARTINS, F.R.; TAMASHIRO, J.Y.; SHEPERD, G.J. How rich is the flora of Brazilian cerrados? Annals of the Missouri Botanical Garden, v.86, n.1, p.192-224, 1999.

CASTRO, E.R. de; GALLETTI, M. Frugivoria e dispersão de sementes pelo lagarto teiú Tupinambis merianae (Reptilia: Teiidae). Papéis Avulsos de Zoologia, v.44, n.6, p.91-97, 2004.

CHAMBERS, G.K.; MACAVOY, E.S. Microsatellites: consensus and controversy. Comparative Biochemistry and Physiology Part B, v.126, n.4, p.455-476, 2000.

CHARLESWORTH, D.; CHARLESWORTH, B. Inbreeding depression and its evolutionary consequences. Annual Review of Ecology and Systematics, v.18, p.237-268, 1987.

CHASE, M.R.; MOLLER, R.; KESSELI, R.; BAWA, K.S. Distant gene flow in tropical trees. Science, v.383, p.398-399, 1996.

CHAVES-FILHO, J.T.; STACCIARINI-SERAPHIN, E. Alteração do potencial osmótico e do teor de carboidratos solúveis em plantas jovens de lobeira (Solanum lycocarpum St.Hil) em resposta ao estresse hídrico. Revista Brasileira de Botânica, v.24, n.2, p.199-204, 2001.

CLEGG, M.T. Measuring plant mating systems. BioScience, v.30, n.12, p.814-818, 1980.

COCKERHAM, C.C. Variance of gene frequencies. Evolution, v.23, n.1, p.72-84, 1969. COCKERHAM, C.C.; WEIR, B.S. Estimation of gene flow from F-statistics. Evolution, v.47, n.3, p.855-863, 1993.

COELHO, A.S.G. Programa EG: Análise de estrutura genética de populações pelo método da análise de variância (software). Universidade Federal de Goiás, Instituto de Ciências Biológicas, Departamento de Biologia Geral, Goiânia, Goiás, 2000.

COELHO, M. de A. Geografia do Brasil. 4.ed., São Paulo: Moderna, 1996. 490p.

COLEMAN, J.R. Chromosome number of angiosperms collected in the State of São Paulo. Revista Brasileira de Genética, v.5, n.3, p.533-549, 1982. 
COLLEVATTI, R.G.; BRONDANI， R.A.; GRATTAPAGLIA， D. Development and characterization of microsatellite markers for genetic analysis of a Brazilian endangered tree species Caryocar brasiliense. Heredity, v.83, n.6, p.748-756, 1999.

COLLEVATTI, R.G.; GRATTAPAGLIA, D.; HAY, J.D. High resolution microsatellite based analysis of the mating system allows the detection of significant biparental inbreeding in Caryocar brasiliense, an endangered tropical tree species. Heredity, v.86, n.1, p.60-67, 2001a.

COLLEVATTI, R.G.; GRATTAPAGLIA, D.; HAY, J.D. Population genetic structure of the endangered tropical tree species Caryocar brasiliense, based on variability at microsatellite loci. Molecular Ecology, v.10, n.2, p.349-356, 2001b.

COLLEVATTI, R.G.; GRATTAPAGLIA, D.; HAY, J.D. Evidences for multiple maternal lineages of Caryocar brasiliense populations in the Brazilian Cerrado based on the analysis of chloroplast DNA sequences and microsatellite haplotype variation. Molecular Ecology, v.12, n.1, p.105-115, 2003.

CORRIVEAU, J.L.; COLEMAN, A.W. Rapid screening method to detect potential biparental inheritance of plastid DNA and results for over 200 angiosperm species. American Journal of Botany, v.75, n.10, p.1443-1458, 1988.

COURTENAY, O. Conservation of the maned wolf: fruitful relations in a changing environment. Canid News, v.2, p.41-43, 1994.

COUTINHO, L.M. O conceito de cerrado. Revista Brasileira de Botânica, v.1, n.1, p.17-23, 1978.

CRESTE, C.; TULMANN NETO, A.; FIGUEIRA, A. Detection of single sequence repeat polymorphisms in denaturing polyacrylamide sequencing gels by silver staining. Plant Molecular Biology Reporter, v.19, n. 4, p.299-306, 2001.

CRUZ, G.L. Dicionário das plantas úteis do Brasil. 2.ed. Rio de Janeiro: Civilização Brasileira. 1982. 599p.

CUNNINGHAM, S.A. Depressed pollination in habitat fragments causes low fruit set. Proceedings of the Royal Society of London, v.267, p.1149-1152, 2000. 
DALL'AGNOL, R.; VON POSER, G.L. The use of complex polysaccharides in the management of metabolic diseases: the case of Solanum lycocarpum fruits. Journal of Ethnopharmacology, v.71, n.1-2, p.337-341, 2000.

DALPONTE, J.C.; LIMA E.S. Disponibilidade de frutos e a dieta de Lycalopex vetulus (Carnivora - Canidae) em um cerrado de Mato Grosso, Brasil. Revista Brasileira de Botânica v.22, n.2, p.325-3352, 1999. Suplemento.

DAYNANDAN, S.; BAWA, K.S.; KESSELI, R. Conservation of microsatellite among tropical tree (Leguminosae). American Journal of Botany, v.84, n.12, p.16581663, 1997.

DEMESURE, B.; SODZI, N.; PETIT, R.J. A set of universal primers for amplification of polymorphic non-coding regions of mitochondrial and chloroplast DNA in plants. Molecular Ecology, v.4, p.129-131, 1995.

DIAS, B.F. de S. Cerrados: uma caracterização. In: DIAS, B.F. de S. (Ed.) Alternativas de desenvolvimento dos cerrados: manejo e conservação dos recursos naturais renováveis. Brasília: FUNATURA-IBAMA, 1992. p. 11-25.

DIETZ, J.M. Ecology and social organization of the maned wolf (Chrysocyon brachyurus) Smithsonian Contributions to Zoology, v.392, p.1-51, 1984.

DIGGLE, P.K. Developmental plasticity, genetic variation, and the evolution of andromonoecy in Solanum hirtum (Solanaceae). American Journal of Botany, v.8, n.8, p.967-973, 1993.

DINIZ-FILHO, J.A.F. Análise de autocorrelação espacial: Inferências microevolutivas e aplicações em genética de populações. Ribeirão Preto: SBG, 1997. p. 83-145. (Série Monografias, 6).

ELIAS, S.M.; ASSIS, R.M. STACCIARINI-SERAPHIN,E. REZENDE, M.H. Anatomia foliar em plantas jovens de Solanum lycocarpum St.Hil. (Solanaeceae). Revista Brasileira de Botânica, v.26, n.2, p.169-174, 2003.

ELLSTRAND, N.C. Gene flow of pollen: implications for plant conservation genetics. Oikos, v.63, p.77-86, 1992.

ELLSTRAND, N.C.; ELAM, D.R. Population genetics consequences of small population size: implications for plant conservation. Annual Review of Ecology and Systematics, v.24, p.217-242, 1993. 
ENNOS, R.A. Estimating the relative rates of pollen and seed migration among plant populations. Heredity, v.72, p.250-259, 1994.

EPPERSON, B.K. Spatial patterns of genetic variation within plant populations. In: BROWN, A.H.D.; CLEGG, M.T.; KAHLER, A.L.; WEIR, B.S. (Eds.). Plant population genetics, breeding, and genetic resources. Sunderland: Sinauer Associates, 1990. cap.14, p.229-253.

EPPERSON, B.K. Spatial distributions of genotypes under isolation by distance. Genetics, v.140, n.4, p.1431-1440, 1995.

ESTOUP, A.; JARNE, P.; CORNUET, J.M. Homoplasy and mutation model at microsatellite loci and their consequences for population genetics analysis. Molecular Ecology, v.11, n.9, p.1591-1604, 2002.

FERREIRA, M.E.; GRATTAPAGLIA, D. Introdução ao uso de marcadores RAPD e RFLP em análise genética. 3.ed. Brasília: EMBRAPA-CENARGEN, 1998. 220p. FRANKEL, O.H.; SOULÉ, M.E. Conservation and evolution. Cambridge: Cambridge University Press, 1981. 327p.

FRANKEL, O.H.; BROWN, A.H.D.; BURDON, J.J. The conservation of plant biodiversity. Cambridge: Cambridge University Press, 1995. 299p.

FRANKLIN, I.R. Evolutionary changes in small population. In: SOULÉ, M.E.; WILCOX, B.A. (Eds.) Conservation Biology: an evolutionary-ecological perspective. Sunderland: Sinauer, 1980. p. 135-149.

FREEMAN, S.; HERRON, J.C. Evolutionary analysis. 2.ed. Upper Saddle River: Prentice-Hall, 2001. 704p.

FUCHS, E.J.; LOBO, J.A.; QUESADA, M. Effects of forest fragmentation and flowering phenology on the reproductive success and mating patterns of the tropical dry forest tree Pachira quinata. Conservation Biology, v.17, n.1, p.149-157, 2003.

FUTUYMA, D.J. Biologia evolutiva. 2.ed. Ribeirão Preto: Sociedade Brasileira de Genética/CNPq, 1992. 646p.

GAIOTTO, F.A.; BRONDANI, R.P.V.; GRATTAPAGLIA, D. Microsatellite primers for heart of palm - Euterpe edulis and E. oleraceae Mart. (Arecaceae). Molecular Ecology Notes, v.1, n.1, p.86-88, 2001. 
GILBERT, L.E. Food web organization and the conservation of neotropical diversity. In: SOULÉ, M.E.; WILCOX, B.A. (Eds.) Conservation Biology: an evolutionaryecological perspective. Sunderland: Sinauer Associates, 1980. cap2, p.11-33.

GLAUBITZ, J.C.; MORAN, G.F. Genetic tools: the use of biochemical and molecular markers. In: YOUNG, A.; BOSHIER, D.; BOYLE, T. (Eds.) Forest conservation genetics: principles and practice. Collingwood: CSIRO Publishing, 2000. cap. 04, p.39-59.

GOLDSTEIN, D.B.; POLLOCK, D.D. Lauching microsatellites: a review of mutation processes and methods of phylogenetic inference. Journal of Heredity, v.88, n.5, p.335-342, 1997.

GOODMAN, S.J. R RTCalc: a collection of computer programs for calculating estimates of genetic differentiation from microsatellite data and determining their significance. Molecular Ecology, v.6, n.9, p.881-885, 1997.

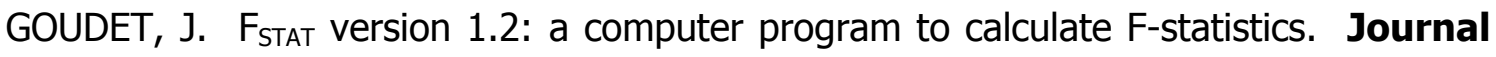
of Heredity, v.86, n.6, p.485-486, 1995.

HALL, P.; ORRELL, L.C.; BAWA, K.S. Genetic diversity and mating system in a tropical tree, Carapa guianensis (Meliaceae). American Journal of Botany, v.81, n.9, p.1104-1111, 1994.

HALL, P.; WALKER, S.; BAWA, K.S. Effect of forest fragmentation on genetic diversity and mating system in a tropical tree, Pithecellobium elegans. Conservation Biology, v.10, n.3, p.757-768, 1996.

HAMILTON, M.B. Tropical tree gene flow and seed dispersal. Nature, v.401, n.6749, p.129-130, 1999.

HAMILTON, M.B.; MILLER, J.R. Comparing relative rates of pollen and seed gene flow in the island model using nuclear and organelle measures of population structure. Genetics, v.162, n.4, p.1897-1909, 2002.

HAMRICK, J.L.; GODT, M.J.W. Conservation genetics of endemic plant species. In: AVISE, J.C.; HAMRICK, J.C. (Eds.) Conservation Genetics: case histories from nature. New York: Chapman \& Hall, 1996. cap.9, p. 281-304.

HAMRICK, J.L.; MURAWSKI, D.A. The breeding structure of tropical tree populations.

Plant Species Biology, v.5, n.1, p.157-165, 1990. 
HAMRICK, J.L.; NASON, J.D. Gene flow in forest trees. In: YOUNG, A.; BOSHIER, D.; BOYLE, T. (Eds.) Forest conservation genetics: principles and practice. Collingwood: CSIRO Publishing, 2000. cap.06, p.81-89.

HARDY, O.J.; VEKEMANS, X. SPAGeDi: a versatile computer program to analyse spatial genetic structure at the individual or population levels. Molecular Ecology Notes, v.2, n.4, p.618-620, 2002.

HARTL, D.L.; CLARK, A.G. Principles of population genetics. 3.ed. Sunderland: Sinauer Associates, 1997. 542p.

HEDRICK, P.W. Highly variable loci and their interpretation in evolution and conservation. Evolution, v.53, n.2, p.313-318, 1999.

HEYWOOD, J.S. Spatial analysis of genetic variation in plant populations. Annual Review of Ecology and Systematics, v.22, p.335-355, 1991.

HOFFMANN, W.A. Post-burn reproduction of woody plants in a neotropical savanna: the relative importance of sexual and vegetative reproduction. Journal of Applied Ecology, v.35, n.3, p.422-433, 1998.

HOWE, H.F.; SMALLWOOD, J. Ecology of seed dispersal. Annual Review of Ecology and Systematics, v.13, p.201-208, 1982.

HU, X.-S.; ENNOS, R.A. On estimation of the ratio of pollen to seed flow among plant populations. Heredity, v.79, n.5, p.541-552, 1997.

JAIN, S.K. Genetics and demography of rare plants and patchly distributed colonizing species. In: LOESCHCKE, V.; TOMIUK, J.; JAIN, S.K. (Eds.) Conservation Genetics. Basel: Birkhauser Verlag, 1994.

JAMES, T.; VEGES, S.; ALDRICH, P.; HAMRICK, J.S. Mating system of tree tropical dry forest tree species. Biotropica, v.30, n.4, p.587-594, 1998.

JARNE, P.; LAGODA, P.J.L. Microsatellites, from molecules to populations and back. Trends in Ecology and Evolution, v.11, n.10, p.424-429, 1996.

KAGEYAMA, P.Y.; GANDARA, F.B; VENCOVSKY, R. Conservação in situ de espécies arbóreas tropicais. In: NASS, L.L.; VALOIS, A.C.C.; MELO, I.S DE; VALADARESINGLIS, M.C. (Eds.) Recursos Genéticos e Melhoramento - Plantas. Rondonópolis: Fundação MT, 2001. cap.7, p.149-158. 
KEARNS, C.A.; INOUYE, D.W.; WASER, N.M. Endangered mutualism: the conservation of plant-pollinator interactions. Annual Review of Ecology and Systematics, v.29, p.83-112, 1998.

LACERDA, D.R.; ACEDO, M.D.P.; LEMOS FILHO, J.P.; LOVATO, M.B. Genetic diversity and structure of natural populations of Plathymenia reticulata (Mimosoideae), a tropical tree from the Brazilian Cerrado. Molecular Ecology, v.10, n.5, p.1143$1152,2001$.

LE BOURLEGAT, C.A. A fragmentação da vegetação natural e o paradigma do desenvolvimento rural. In: COSTA, R.B. da (Org.) Fragmentação florestal e alternativas de desenvolvimento rural na região Centro-Oeste. Campo Grande: UCDB, 2003. cap.1, p.1-25.

LEVIN, D.A. Dispersal versus gene flow in plants. Annals of the Missouri Botanical Garden, v.68, n.2, p.233-253, 1981.

LEWIS, P. O.; ZAYKIN, D. Genetic Data Analysis: computer program for the analysis of allelic data. Version 1.0 2001. http://lewis.eeb.uconn.edu/lewishome/software.html (09 Jun. 2002)

LOMBARDI, J.A.; MOTTA-JUNIOR, J.C. Seed dispersal of Solanum lycocarpum St.Hil. (Solanaceae) by the maned wolf, Chrysocyon brachyurus Illiger (Mammalia, Canidae). Ciência e Cultura, v.45, p.126-127, 1993.

LORENZI, H. Árvores Brasileiras: Manual de Identificação e Cultivo de Plantas Arbóreas Nativas do Brasil. Nova Odessa: Plantarum, 1998. v.2.

LOVELESS, M.D.; HAMRICK, J.L. Ecological determinants of genetic structure in plant populations. Annual Review of Ecology and Systematics, v.15, p.65-95, 1984.

LYNCH, M. A quantitative-genetic perspective on conservation issues. In: AVISE, J.C.; HAMRICK, J.L. Conservation Genetics: case histories from nature. New York: Chapman \& Hall, 1996. p. 471-501.

LYNCH, M.; RITLAND, K. Estimation of pairwise relatedness with molecular markers. Genetics, v.152, n.4, p.1753-1766, 1999. 
MACHADO, R.B.; RAMOS NETO, M.B.; PEREIRA, P.G.P.; CALDAS, E.F.; GONÇLAVES, D.A.; SANTOS, N.S.; TABOR, K.; STEININGER, M. Estimativas de perda da área do cerrado brasileiro. Relatório Técnico. Brasília: Conservation International, 2004. 26p.

MANTEL, N. The detection of disease clustering and a generalized regression approach. Cancer Research, v.27, p.209-220, 1967.

MARSHALL, T.C.; SLATE, J.; KRUUK, L.; PEMBERTON, J.M. Statistical confidence for likelihood-based paternity inference in natural populations. Molecular Ecology, v.7, n.5, p.639-655, 1998.

MARTINS, K.; MOTTA-JUNIOR, J.C. The maned wolf, Chrysocyon brachyurus (Mammalia: Canidae), as seed disperser of Solanum lycocarpum (Solanaceae) in Southeastern Brazil: a test with captive animals. In: INTERNATIONAL SYMPOSIUMWORKSHOP ON FRUGIVORES AND SEED DISPERSAL, 3., São Pedro, 2000. Resumos. São Pedro: UNICAMP/UNESP 2000. p.217.

MCCAULEY, D.E. Contrasting the distribution of chloroplast DNA and allozyme polymorphisms among local populations of Silene alba: Implications for studies of gene flow in plants. Proceedings of the National Academy of Sciences of the United States of America, v.91, p.8127-8131, 1994.

MCCAULEY, D.E. The use of chloroplast DNA polymorphism in studies of gene flow in plants. Trends in Ecology and Evolution, v.10, n.5, p.198-202, 1995.

MEAGHER, T.R. Analysis of paternity within a natural population of Chamaelirium Iuteum. I. Identification of most-likely male parents. American Naturalist, v.128, n.2, p.199-215, 1986.

MELO JÚNIOR, A.F.; CARVALHO, D. DE; POVOA,J.S.R.; BEARZOTI, E. Estrutura genética em populações naturais de pequizeiro (Caryocar brasiliense Camb.) Scientia forestalis, v.66, n.2, p.56-65, 2004.

MILLIGAN, B.G. Is organelle DNA strictly maternally inherited? Power analysis of a binomial distribution. American Journal of Botany, v.79, n.11, p.1325-1328, 1992. 
MMA. Biodiversidade brasileira: Avaliação e identificação de áreas e ações prioritárias para a conservação, utilização sustentável e repartição de benefícios da biodiversidade nos biomas brasileiros. Brasília: MMA/SBF, 2002. 404p.

MONGENSEN, H.L. The hows and whys of cytoplasmic inheritance in seed plants. American Journal of Botany, v.83, n.3, p.383-404, 1996.

MORGANTE, M.; HANAFEY, M.; POWELL, W. Microsatellites are preferentially associated with nonrepetitive DNA in plant genomes. Nature Genetics, v.30, p.194-200, 2002. MOTTA-JUNIOR, J.C.; MARTINS, K. The Frugivorous diet of the maned wolf, Chrysocyon brachyurus in Brazil: Ecology and conservation. In: LEVEY, D.J.; SILVA, W.R.; GALETTI, M.(Eds.) Seed dispersal and frugivory: ecology, evolution and conservation. Wallingford: CABI Publishing, 2002. cap.19, p.291-303.

MOTTA-JUNIOR, J.C.; TALAMONI, S.A.; LOMBARDI, J.A.; SIMOKOMAKI, K. Diet of maned wolf, Chrysocyon brachyurus, in central Brazil. Journal of Zoology, London, v.240, p.277-284, 1996.

MOURA, T.M. Biologia reprodutiva e estrutura genética populacional em lobeira do cerrado (Solanum lycocarpum St.Hil) no município de Morrinhos-GO. Morrinhos, 2004. 83p. Monografia (Graduação) - Universidade Estadual de Goiás.

MURAWSKI, D.A.; HAMRICK, J.L. The effect of the density of flowering individuals on the mating systems of nine tropical tree species. Heredity, v.67, n. 2, p.167-174, 1991.

MURAWSKI, D.A.; HAMRICK, J.L. The mating system of Cavanillesia platanifolia under extremes of flowering-tree density: a test of predictions. Biotropica, v.24, n.1, p.99$101,1992$.

MURAWSKI, D.A.; BAWA, K.S. Genetic structure and mating system of Stemonoporus oblongifolius (Dipterocarpaceae) in Sri Lanka. American Journal of Botany, v.81, n.2, p.155-160, 1994.

MYERS, N.; MITTERMEIER, R.A.; MITTERMEIER, C.G.; FONSECA, G.A.B. DE; KENT, J. Biodiversity hotspots for conservation priorities. Nature, v.403, n.6772, p.853-858, 2000. 
NAMKOONG, G.; BOYLE, T.; EL-KASSABY, Y.A.; PALMBERG-LERCHE, C.; ERIKSSON, G.; GREGORIUS, H.-R.; JOLY, H.; KREMER, J.A.; SAVOLAINEN, O.; WICKNESWARI, R.; YOUNG, A.; ZEH-NLO, M.; PRABHU, R. Criteria and indicators sustainable forest management: assessment and monitoring of genetic variation. Roma: FAO, 2002. 29p.

NASON, J.D.; HAMRICK, J.L. Reproductive and genetic consequences of forest fragmentation: two case studies of Neotropical canopy trees. Journal of Heredity, v.88, p.264-276, 1997.

NAVASCUÉS, M.; EMERSON, C. Chloroplast microsatellites: measures of genetic diversity and the effect of homoplasy. Molecular Ecology, v.14, n.5, p.1333-1341, 2005.

NEI, M. Genetic distance between populations. American Naturalist, v.106, n.949, p.283-292, 1972.

NEI, M. F-statistics and analysis of gene diversity in subdivided populations. Annals of Human Genetics, v.41, p.225-233, 1977.

NEIGEL, J.E. A comparison of alternative strategies for estimating gene flow from genetic markers. Annual Review of Ecology and Systematics, v.28, p.105-128, 1997.

ODDOU-MURATORIO, S.; PETIT, R.J.; L E GUERROUE, B.; GUESNET, D.; DEMESURE, B. Pollen- to seed-mediated gene flow in scattered forest tree species. Evolution, v.55, n.6, p.1123-1135, 2001.

OLIVEIRA-FILHO, A.T.; OLIVEIRA, L.C.A. Biologia floral de uma população de Solanum lycocarpum St Hil (Solanaceae) em Lavras, MG. Revista Brasileira de Botânica, v.11, n.1, p.23-32, 1988.

OUBORG, N.J.; PIQUOT, Y.; VAN GROENEDAEL, J.N. Population genetics, molecular markers and the study of seed dispersal in plants. Journal of Ecology, v.87, n.4, p.551-568, 1999.

PALMER, J.D. Chloroplast DNA evolution and biosystematics uses of chloroplast DNA variation. American Naturalist, v.130, p.6-29, 1987. Suplement. 
PEAKALL, R.; SMOUSE, P.E. GenAlEx v5: Genetic Analysis in Excel. Population genetic software for teaching and research. Australia National University, Canberra, Australia. 2001.

PEREIRA, M. de F. Estrutura genética de populações de espécies arbóreas nativas do cerrado encontradas em terrenos serpentínicos. Goiânia, 2003. 76p. Dissertação (Mestrado) - Escola de Agronomia e Engenharia de Alimentos, Universidade Federal de Goiás.

PETIT, R.J.; KREMER, A.; WAGNER, D.B. Finite island model for organelle and nuclear genes in plants. Heredity, v.71, n.6, p.630-641, 1993.

PETIT, R.J.; DUMINIL,J.; FINESCHI,S.; HAMPE, A.; SALVINI, D; VENDRAMIN, G.G. Comparative organization of chloroplast, mitochondrial and nuclear diversity in plant populations. Molecular Ecology, v.14, n.3, p.689-701, 2005.

PIJL, L. VAN DER. Principles of Dispersal in Higher Plants. 2.ed. New York: Springer Verlag, 1972. 161p.

PINTO F.S. Efeitos da dispersão de sementes por animais e dos fatores edáficos sobre a germinação, crescimento e sobrevivência das plântulas de lobeira, Solanum lycocarpum. Brasília, 1998. 97p. Dissertação (Mestrado) - Departamento de Ecologia, Universidade de Brasília.

PINTO, F.; BORGHETTI, F; RAW, A. Three seed dispersers get seeds to the same safe site: the importance of the Solanum lycocarpum (Solanaceae) association with leafcutter ant nests In: INTERNATIONAL SYMPOSIUM-WORKSHOP ON FRUGIVORES AND SEED DISPERSAL, 3., São Pedro, 2000. Resumos. São Pedro: UNICAMP/UNESP 2000. p. 239.

PIO CORRÊIA, M.P. Dicionário das plantas úteis do Brasil e exóticas cultivadas.

Rio de Janeiro: Ministério da Agricultura, Instituto Brasileiro de Desenvolvimento Florestal, 1984. v.3, p.325-328.

PIRES, M.O.; SANTOS, I.M. dos. (Org.) Construindo o cerrado sustentável: experiências e contribuições das ONG's. Brasília: Gráfica Nacional, 2000. 147p.

PROVAN, J.; POWELL, W.; WAUGH, R. Microsatellite analysis of relationships within cultivated potato (Solanum tuberosum). Theoretical and Applied Genetics, v.92, n.8, p.1078-1084, 1996. 
PROVAN, J.; SORANZO, N.; WILSON, N.J.; GOLDSTEIN, D.B.; POWELL, W. A low mutation rate for chloroplast microsatellites. Genetics, v.153, n.2, p.943-947, 1999.

PROVAN, J.; BISS, P.M.; MCMEEL, D.; MATHEWS, S. Universal primers for the amplification of chloroplast microsatellites in grasses (Poaceae). Molecular Ecology Notes, v.4, n.2, p.262-264, 2004.

RASPE, O.; SAUMITOU-LAPRADE, P.; CUGUEN, J.; JACQUEMAR, A.L. Chloroplast DNA haplotype variation and population differentiation in Sorbus aucuparia L. (Rosaceae: Malidae). Molecular Ecology, v.9, n.8, p.1113-1122, 2000.

RATTER, J.A.; RIBEIRO, J.F.; BRIDGEWATER, S. The Brazilian cerrado vegetation and threats to its biodiversity. Annals of Botany, v.80, n.3, p.223-230, 1997.

RIBEIRO, J.F.; SILVA, J.C.S. Manutenção e recuperação da biodiversidade do bioma do cerrado: o uso de plantas nativas. In: SIMPÓSIO SOBRE O CERRADO, 8, Brasília, 1996. Anais. Planaltina: EMBRAPA-CPAC,1996. p.10-13.

RIDLEY, M. Evolution. 2.ed. Cambridge: Blackwell Science, 1996. 719p.

RITLAND, K. Correlated matings in the partial selfer Mimulus guttatus. Evolution, v.43, n.4, p.848-859, 1989.

RITLAND, K. Extensions of models for the estimation of mating systems using $n$ independent loci. Heredity, v.88, n.4, p.221-228, 2002.

RITLAND, K.; JAIN, S. A model for the estimation of outcrossing rate and gene frequency using $n$ independent loci. Heredity, v.47, n.1, p.35-52, 1981.

RIZZINI, C.T.; HERINGER E.P. Studies on the underground organs of trees and shrubs from some southern Brazilian savannas. Anais da Academia Brasileira de Ciências, v.34, p.235-247, 1962.

ROA, A.C.; ChAVARRIAGA-AGUIRRE, P.; DUQUE, M.C.; MAYA, M.M.; BONIERBALE, M.W.; IGLESIAS, C.; THOME, J. Cross species amplification of cassava (Manihot esculenta) (Euphorbiaceae) microsatellites: allelic polymorphism and degree of relationship. American Journal of Botany, v.87, n.11, p.1647-1655, 2000.

RODRIGUES, F.H.G. Biologia e conservação do lobo-guará na Estação Ecológica de Águas Emendadas, DF. Campinas, 2002. 96p. Dissertação (Mestrado) - Instituto de Biologia, Universidade Estadual de Campinas. 
RODRIGUES, F.H.G.; HASS, A.; BIZERRIL, M.X.A.; GRANDO, R.L.S.; LACERDA, A.C.R.; SILVA, W.R. The maned wolf and the maned wolf fruit. In: INTERNATIONAL SYMPOSIUM-WORKSHOP ON FRUGIVORES AND SEED DISPERSAL, 3., Resumos. São Pedro: UNICAMP/UNESP 2000. p.249.

ROEL, A.R.; ARRUDA, E.J. Agroecologia e os recursos naturais de fragmentos de vegetação nativa. In: COSTA, R.B. da (Org.) Fragmentação florestal e alternativas de desenvolvimento rural na região Centro-Oeste. Campo Grande: UCDB, 2003. cap. 9, p.205-239.

ROHLF, F.J. NTSYS-Pc: Numerical Taxonomy and Multivariate Analysis System. New York: Exeter publisher, 1989.

SANTOS, E.F.; SETZ, E.Z.F.; GOBBI, N. Diet of the maned wolf (Chrysocyon brachyurus) and its role in seed dispersal on a cattle ranch in Brazil. Journal of Zoology, London, v.260, p.203-208, 2003

SARDAGNA, A.A.; WELTER, I.; BOITEUX; BUSO, G.S.C.; FERREIRA, M.E. Conservação de regiões flanqueadoras de locos hipervariáveis do gênero Capsicum spp em outros gêneros de Solanaceae. (compact disc) In: CONGRESSO NACIONAL DE GENÉTICA, 47., Águas de Lindóia, 2001. Resumos. Águas de Lindóia: SBG, 2001.

SAUNDERS, D.A.; HOBBS, R.J.; MARGULES, C.R. Biological consequences of ecosystem fragmentation: a review. Conservation Biology, v.5, n.1, p.18-32, 1991

SCHLÖTTERER, C. The evolution of molecular markers - just a matter of fashion? Nature Genetics Reviews, v.5, p.63-69, 2004.

SEBBENN, A.M. Tamanho efetivo para conservação 'ex situ' de espécies arbóreas com sistema misto de reprodução. Revista do Instituto Florestal, v.15, n.2, p.147162, 2003.

SEBBENN, A.M.; KAGEYAMA, P.Y.; VENCOVSKY, R. Conservação genética 'in situ' e número de matrizes para a coleta de sementes em populações de Genipa americana L. Scientia forestalis, v.63, n.1, p.13-22, 2003.

SILVA, J.A.; SILVA, D.B.; JUNQUEIRA, N.T.V.; ANDRADE, L.R.M. Frutas nativas dos cerrados. Brasília: Embrapa - CPAC, 1994. 166p. 
SILVA, J.M.C. da; BATES, J.M. Biogeographic patterns and conservation in the South American Cerrado: a tropical savanna hotspot. BioScience, v.52, n.3, p.225-233, 2002.

SLATKIN, M. Gene flow in natural populations. Annual Review of Ecology and Systematics, v.16, p.393-430, 1985.

SLATKIN, M. Gene flow and the geographic structure of natural populations. Science, v.236, p.787-792, 1987.

SLATKIN, M. Isolation by distance in equilibrium and non-equilibrium poulations. Evolution, v.47, n.1, p.264-279, 1993.

SLATKIN, M. A measure of population subdivision based on microsatellite allele frequencies. Genetics, v.139, n.1, p.457-462, 1995.

SLATKIN, M.; BARTON, N.H. A comparison of three indirect methods for estimating average levels of gene flow. Evolution, v.43, n.7, p.1349-1368, 1989.

SMOUSE, P.E.; PEAKALL, R. Spatial autocorrelation analysis of individual multiallele and multilocus genetic structure. Heredity, v.82, n. 5, p.561-573, 1999.

SMULDERS, M.J.M.; BREDEMEIJER, G.; RUS-KORTEKAAS, W.; ARENS, P.; VOSMAN, B. Use of short microsatellites from database sequences to generate polymorphisms among Lycopersicon esculentum cultivars and accessions of the Lycopersicon species. Theoretical and Applied Genetics, v.97, n.1-2, p.264-272, 1997.

SORK, V.L.; NASON, J.; CAMPBELL, D.R.; FERNANDEZ, J.F. Landscape approaches to historical and contemporary gene flow in plants. Trends in Ecology and Evolution, v.14, n.6, p.219-224, 1999.

SORK, V.L.; CAMPBELL, D.; DYER, R.; FERNANDEZ, J.; NASON, J.; PETIT, R.; SMOUSE, P.; STEINBERG, E. Proceedings from a workshop on gene flow in fragmented, managed, and continuous populations. Research paper $\mathbf{n}^{\circ}$ 03. Santa Bárbara: Califórnia, NCEAS. http://www.nceas.ucsb.edu/nceas-web/projects/2057/nceas-paper3/ (08 Mar.1998)

SOULÉ, M.E. Introduction. In: SOULÉ, M.E. (Ed.) Viable populations for conservation. Cambridge: Cambridge University Press, 1996. cap.1, p.1-10. 
SOUZA-JÚNIOR, E.E. de. Análise da estrutura genética e distribuição espacial das espécies vicariantes Caryocar villosum (Aubl.) e C. brasiliense (Camb.) utilizando marcadores SSR. Goiânia, 2003. 101p. Tese (Doutorado) - Escola de Agronomia e Engenharia de Alimentos, Universidade de Goiás.

STEINKELLNER, H.; LEXER, C.; TUTRESSCHEK, E.; GLOSSIL, J. Conservation of (GA)n microsatellite between Quercus species. Molecular Ecology, v.6, n.12, p.11891194, 1997.

STELLA, A. Seleção de espécies arbóreas tropicais prioritárias para a conservação: a caso da Estação Ecológica de Caetetus. Campinas, 2002. 94p. Dissertação (Mestrado) - Instituto de Biologia, Universidade Estadual de Campinas.

STRAND, A.E.; MILLIGAN, B.G.; PRUITT, C.M. Are populations islands? Analysis of chloroplast DNA variation in Aquillegia. Evolution, v.50, n.5, p.1822-1829, 1996.

TABERLET, P.; GIELLY, L.; PAUTOU, G.; BOUVET, J. Universal primers for amplification of three non-coding regions of chloroplast DNA. Plant Molecular Biology, v.17, n.5, p.1105-1109, 1991.

TELLES, M.P.C.; DINIZ-FILHO, J.A.F.; COELHO, A.S.G.; CHAVES, L.J. Autocorrelação especial das freqüências alélicas em subpopulações de cagaiteira (Eugenia dysenterica DC., Myrtaceae) no Sudeste de Goiás. Revista Brasileira de Botânica, v.24, n.2, p.145-154, 2001 a.

TELLES, M.P.C.; SILVA, R.S.M.; CHAVES, L.J.; COELHO, A.S.G.; DINIZ-FILHO, J.A.F. Divergência entre subpopulações de cagaiteira (Eugenia dysenterica) em resposta a padrões edáficos e distribuição espacial. Pesquisa Agropecuária Brasileira, v.36, n.11, p.1387-1394, 2001b.

TELLES, M.P.C.; VALVA, F. D.; BANDEIRA, L.F.; COELHO, A.S.G. Caracterização genética de populações naturais de araticunzeiro (Annona crassiflora Mart. Annonaceae) no estado de Goiás. Revista Brasileira de Botânica, v.26, n.1, p.123-129, 2003 .

TELLES, M.P.C.; COELHO, A.S.G.; CHAVES, L.J.; DINIZ-FILHO, J.A.F.; VALVA, F. D. Genetic diversity and population structure of Eugenia dysenterica DC. ("cagaiteira" Myrtaceae) in Central Brazil: spatial analysis and implications for conservation and management. Conservation Genetics, v.4, n.6, 685-695, $2003 \mathrm{~b}$. 
TEMPLETON, A.R.; SHAW, K.; ROUTMAN, E. DAVIS, S.K. The genetic consequences of habitat fragmentation. Annals of the Missouri Botanical Garden, v.77, n.1, p.13-27, 1990.

TERBORGH, J. Keystone plant resources in the tropical forest. In: SOULÉ, M.E. (Ed.) Conservation Biology: the science of scarcity and diversity. Sunderland: Sinauer Associates, 1986. cap.15, p.330-344.

TRAPNEL, D.W.; HAMRICK, J.L. Partitioning nuclear and chloroplast variation at multiple spatial scales in the neotropical epiphytic orchid, Laelia rubescens. Molecular Ecology, v.13, n.9, p.2655-2666, 2004.

TRINDADE, M.G. Estrutura genética em populações naturais de cagaiteira (Eugenia dysenterica DC) do nordeste de Goiás. Goiânia, 2001. 99p. Dissertação (Mestrado) Escola de Agronomia e Engenharia de Alimentos, Universidade Federal de Goiás.

VENCOVSKY, R. Tamanho efetivo populacional na coleta e preservação de germoplasmas de espécies alógamas. Revista do IPEF, v.35, p.79-84, 1987.

VENCOVSKY, R.; CROSSA J. Measures of representativeness. In: BORÉM, A.; GIÚDICE, M.P.; SAKIYAMA, N.S. (Eds.) Plant Breeding in the turn of the millennium. Viçosa: UFV, 1999. p.335-354.

VENDRAMIN, G.G.; LELLI, L.; ROSSI, P.; MORGANTE, M. A set of primers for the amplification of 20 chloroplast microsatellites in Pinaceae. Molecular Ecology, v.5, n.4, p.595-598, 1996.

VIDAL, M.C. Crescimento inicial, relações hídricas e efeito do ácido abscísico em Solanum lycocarpum St.Hil. (lobeira). Goiânia, 2000. 64p. Dissertação (Mestrado). Universidade Federal de Goiás.

YOUNG, A.G.; BOYLE, T.J. Forest fragmentation. In: A. Young, D. Boshier, T. Boyle (Eds.). Forest conservation genetics: principles and practice. Wallingford: CABI Publishing, 2000. p.123-134.

YOUNG, A.G.; BOYLE, T.; BROWN, T. The population genetic consequences of habitat fragmentation for plants. Trends in Ecology and Evolution, v.11, n.10, p.413418, 1996. 
WAJAH, S.A.; LEVEY, D.J.; SANDERS, A.K.; CIPOLLINI, M.L. Control of seed retention time by secondary metabolites in ripe Solanum fruits. Ecology, v.79, n.7, p.23092319, 1998.

WEIR, B.S. Genetic data analysis II. Sunderland: Sinauer Associates, 1996. 445p. WEISING, K.; GARDNER, R.C. A set of conserved PCR primers for the analysis of simple sequence repeat polymorphisms in chloroplast genome of dicotyledonous angiosperms. Genome, v.42, n.1, p.9-19, 1999.

WHITE, G.; POWELL, W. Cross-species amplification of SSR loci in the Meliaceae family. Molecular Ecology, v.6, n.12, p.1195-1197, 1997.

WHITE, G.M.; BOSHIER, D.H.; POWELL, W. Genetic variation within a fragmented population of Swietenia humilis Zucc. Molecular Ecology, v.8, n.11, p.1899-1909, 1999

WORKMAN, P.; NISWANDER, J.L. Population studies on southwestern Indian Tribes. II. Local genetic differentiation in the Papago. American Journal Human Genetics, v.22, p.24-49, 1970.

WRIGHT, S. Coefficients of inbreeding and relationship. American Naturalist, v.56. n.645, p.330-338, 1922.

WRIGHT, S. Evolution in Mendelian populations. Genetics, v.16, n.2, p.111-123, 1931.

WRIGHT, S. Isolation by distance. Genetics, v.28, n.2, p.139-156, 1943.

WRIGHT, S. The genetical structure of populations. Annals of Eugenics, v.15, p.323-354, 1951.

ZELANDI, E.M.; SOUZA, E.B. de; LOPES, C.R. Caracterização da variabilidade genética em duas populações de Solanum lycocarpum St.Hil. (Solanaceae) por meio do marcador molecular RAPD. Genetics and Molecular Biology, v.22, n.3Suplemento, p. 504, 1999.

ZELANDI, E.M.; SOUZA, E.B. de; LOPES, C.R. Caracterização da variabilidade genética em populações de Solanum lycocarpum St.Hil. (Solanaceae) e de Eugenia jambolana Lamarck (Myrtaceae) pelo marcador molecular RAPD. Genetics and Molecular Biology, v.23, n.3-Suplemento, p.361, 2000. 
ZUCCHI, M.I. Análise da estrutura genética de Eugenia dysenterica DC. utilizando marcadores RAPD e SSR. Piracicaba, 2002. 130p. Tese (Doutorado) - Escola Superior de Agricultura Luiz de Queiróz, Universidade de São Paulo.

ZUCCHI, M.I.; BRONDANI, R.P.V.; PINHEIRO, J.B.; BRONDANI, C.; VENCOVSKY, R. Transferability of microsatellite markers from Eucaplyptus spp to Eugenia dysenterica (Myrtaceae family). Molecular Ecology Notes, v.2, n.4, p.512-514, 2002.

ZUCCHI, M.I.; BRONDANI, R.P.V.; PINHEIRO, J.B.; CHAVES, L.J.; COELHO, A.S.G.; VENCOVSKY, R. Genetic structure and gene flow in Eugenia dysenterica DC in the Brazilian Cerrado utilizing SSR markers. Genetics and Molecular Biology, v.26, n.4, p.449-457, 2003. 